\title{
O CERTIFICADO DE MERCADORIA COM EMISSÃO GARANTIDA (CM-G) COMO FONTE ALTERNATIVA DE FINANCIAMENTO PARA O SETOR AGROPECUÁRIO
}

\author{
TEREZINHA JOYCE FERNANDES FRANCA
}

Dissertação apresentada à Escola Superior de Agricultura "Luiz de Queiroz", da Universidade de São Paulo, para obtenção do título de Mestre em Ciências, Área de Concentração: Economia Aplicada.

\section{PIRACICABA}

Estado de São Paulo - Brasil

Novembro - 1996 


\title{
O CERTIFICADO DE MERCADORIA COM EMISSÃO GARANTIDA (CM-G) COMO FONTE ALTERNATIVA DE FINANCIAMENTO PARA O SETOR AGROPECUÁRIO
}

\author{
TEREZINHA JOYCE FERNANDES FRANCA \\ Economista
}

Orientador: Prof. Dr. Joaquim José Martins Guilhoto

Dissertação apresentada à Escola Superior de Agricultura "Luiz de Queiroz", da Universidade de São Paulo, para obtenção do titulo de Mestre em Ciências, Área de Concentra ção: Economia Aplicada.

\author{
PIRACICABA \\ Estado de São Paulo - Brasil
}

Novembro - 1996 


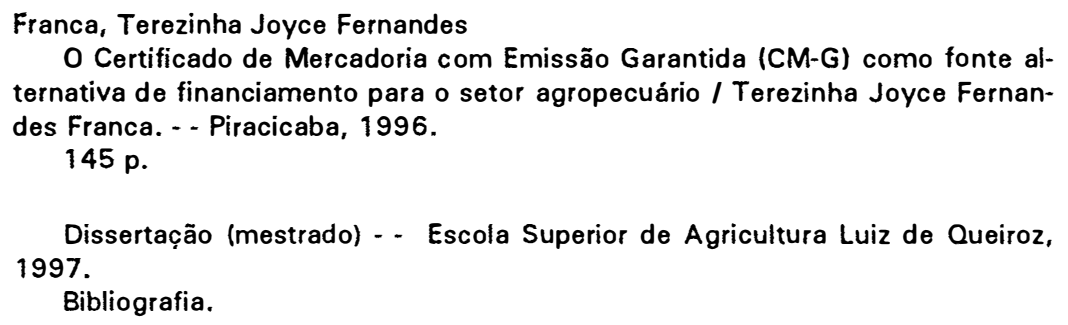

Dissertação (mestrado) - Escola Superior de Agricultura Luiz de Queiroz, 1997.

Bibliografia.

1. Crédito agrícola 2. Financiamento agrícola I. Título 


\title{
O CERTIFICADO DE MERCADORIA COM EMISSÃO GARANTIDA (CM-G) COMO FONTE ALTERNATIVA DE FINANCIAMENTO PARA O SETOR AGROPECUÁRIO
}

\author{
TEREZINHA JOYCE FERNANDES FRANCA
}

Aprovada em: 20/05/97

Comissão julgadora:

Prof. Dr. Joaquim José Martins Guilhoto

ESALQUSP

Prof. Dr. Pedro Valentim Marques

ESALQ/USP

Prof $D r^{2}$ Yara Maria Chagas de Carvalho

IEAISAA

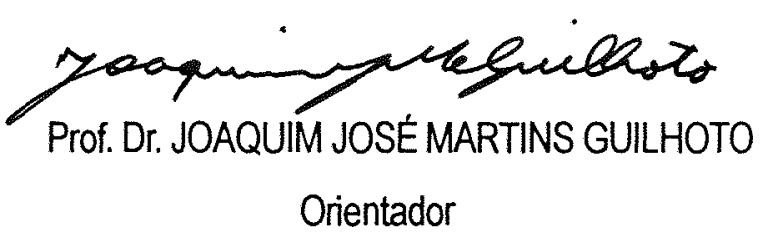


Aos meus pais, Aloisio e Luz Ao meu marido, Marcelo Aos meus filhos, Joana, Fernanda e Victor À minha imã, Mary Anne Aos meus grandes amigos 


\section{AGRADECIMENTOS}

Ao Instituto de Economia Agricola (IEA), pela infraestrutura nas áreas de pessoal, informática e biblioteca, sem o que não seria possivel a elaboração deste trabalho.

Ao Prop . Dr. Joaquim José Martins Guilhoto, pela orientação, atenção e constante estimulo.

Agradecimentos especiais ao Walter Soboll, Ademiro Vian, Roberto Mauri, que por inúmeras vezes concederam entrevistas sobre o CM-G, bem como aos técnicos do Banco do Brasil do Grupo de Trabalho BB-CPR em Brasilia e aos da Superintendência Regional de São Paulo, que sempre estavam dispostos a dar esclarecimentos sobre a CPR.

Agradecimentos especiais as técnicas Yara Maria Chagas de Carvalho, Silene de Freitas e Denyse Chabaribery, colegas do IEA, que através da leitura critica e sugestões, tiveram contribuição fundamental para o desenvolvimento deste trabalho.

Agradecimento especial também a Irene Francisca Lucatto, pelo ótimo trabalho de reprodução e encadernação.

A todos os colegas do IEA e a todas as pessoas que direta ou indiretamente contribuiram para a realização desta dissertação. 


\section{SUMÁRIO}

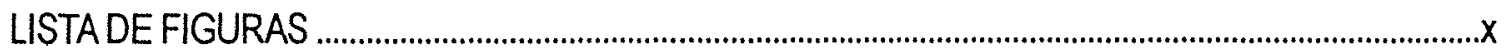

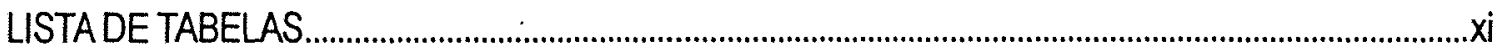

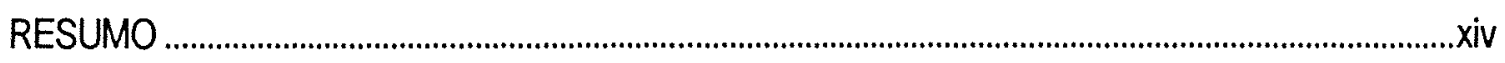

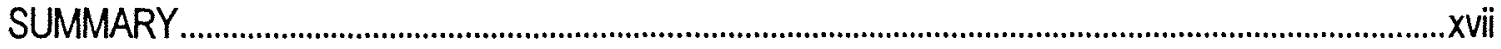

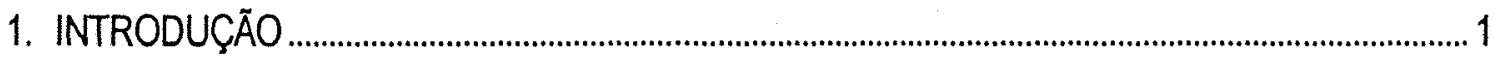

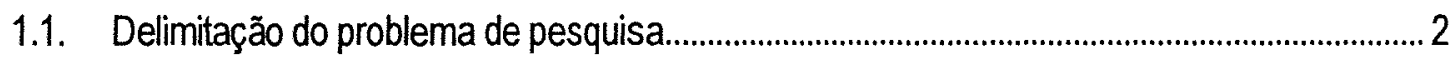

1.1.1. O esgotamento do Sistema Nacional de Crédito Rural (SNCR) .................................. 2

1.1.2. Novos instrumentos de captação de recursos para a agricultura ...............................12

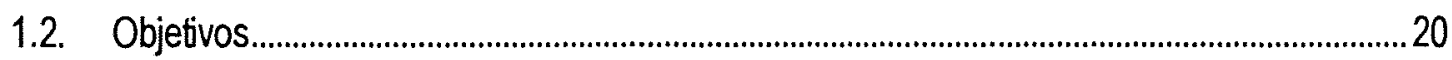

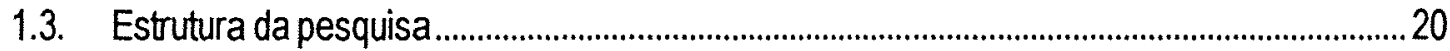

2. METODOLOGIA

2.1. Apresentação do material e método utilizados para a descrição dos componentes analisa-

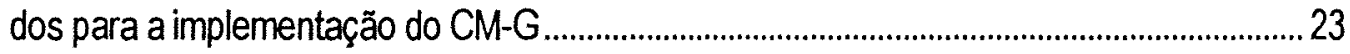

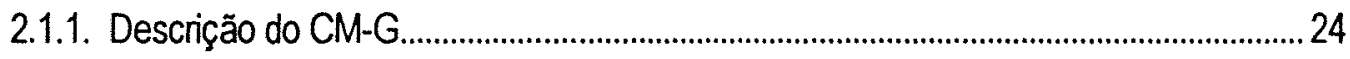

2.1.2. Descrição da estrutura que dá suporte ao CM-G.......................................................25

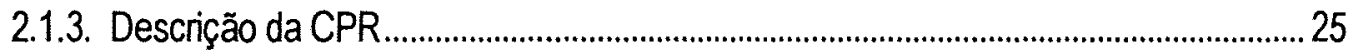

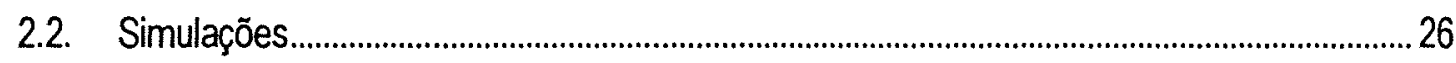

2.2.1. Decomposição do preço FOB/Paranaguá (PFOBPAR) para o valor de negocia-

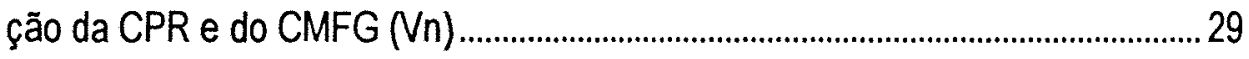

2.2.2. Decomposição do valor de negociação da CPR (VnCPR) para o valor liquido da

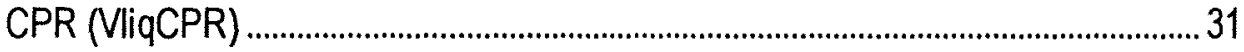

2.2.3. Decomposição do valor de negociação (NnCMFG) para o valor liquido da CMFG

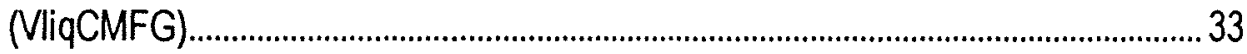

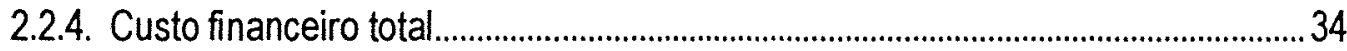

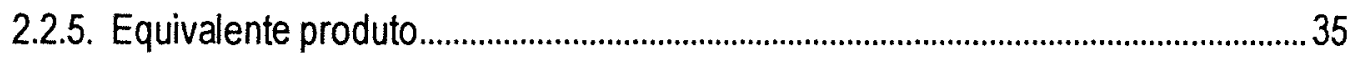




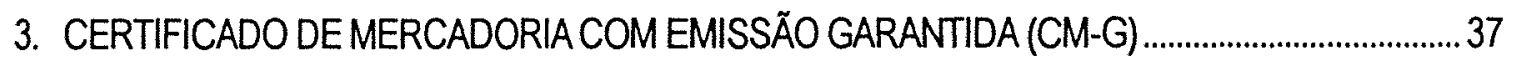

3.1. Principais características e mecanismos operacionais do CM-G ...........................................4 42

3.2. Exemplos do fluxo rotativo do $\mathrm{CM}-\mathrm{G}$ na captação de recursos ...............................................4

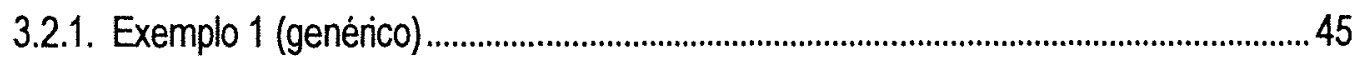

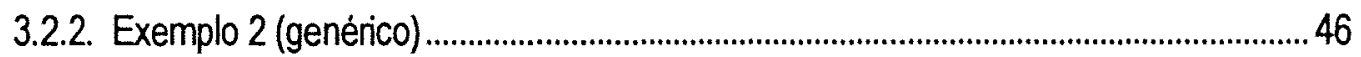

3.2.3. Exemplo 3 - Venda $x$ Compra ......................................................................... 47

3.2.4. Exemplo 4 - Vendedor $x$ Fundo de Investimentos Financeiros $x$ Comprador, ou Vendedor $x$ Comprador $x$ Nova Emissão de Venda (industrializado) $x$ Comprador. 49

3.2.5. Exemplo 5 - Escambo $x$ Dinheiro à Vista............................................................. 49

3.2.6. Exemplo 6 - Estratégias para o credor com a utilização de mercados futuros ...51

3.2.7. Exemplo 7 - Estratégias para 0 credor com a utilização do mercado de. opções............................................................................................ 52

3.2.8. Exemplo 8 - Estratégias para o emitente com a utilização de mercados . futuros ............................................................................................. 52

3.2.9 Exemplo 9 - Estratégias para o emitente com a utilização do mercado de.

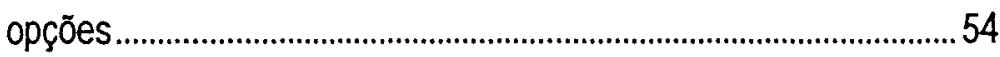

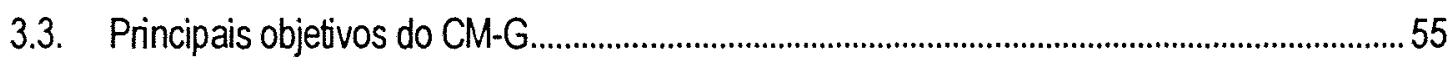

3.4. Principais vantagens do $\mathrm{CM}-\mathrm{G}$..........................................................................................5

3.5. Situação atual do Sistema de Negociação do CM-G..........................................................5

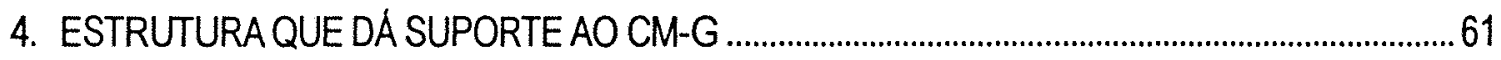

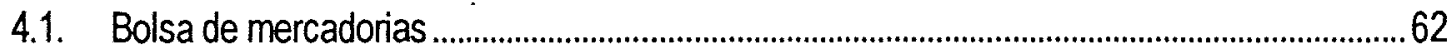

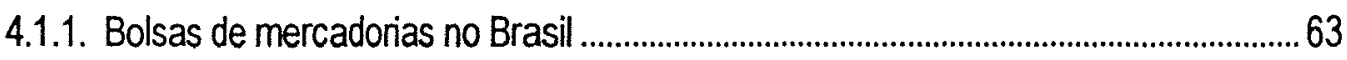

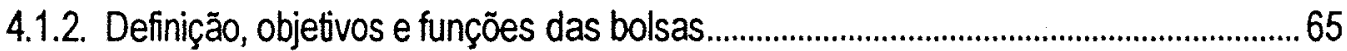

4.1.3. Vantagens da operação em bolsas e desvantagens do "mercado de balcão" ..........66

4.1.4. O CM-Ge a utilização das bolsas ................................................................................ 67

4.2. Câmara de Compensação ....................................................................................................69

4.2.1. Central de Registros $S / A$......................................................................................

4.3. Seguro Garantia de Obrigaçōes Contratuais..........................................................................73 


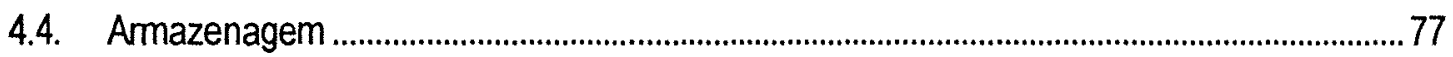

4.4.1. A Situą̧ão da Capacidade de Amazenagem................................................................79

5. ANÁLISE COMPARATIVA DO CM-G EM RELAÇÃO ACPRE AO SNCR ......................................

5.1. Comparação das caracteristicas do CM-G e da CPR........................................................... 86

5.2 Resultado financeiro para o produtor na utilização do CM-G, da CPR e do SNCR ..............95

5.2.1. O produto soja........................................................................................................... 95

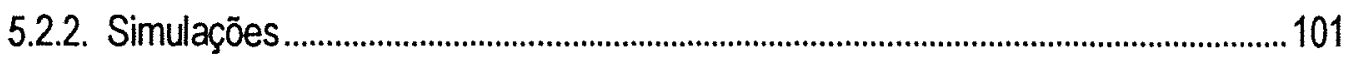

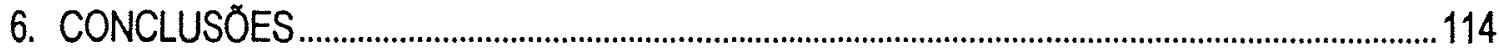

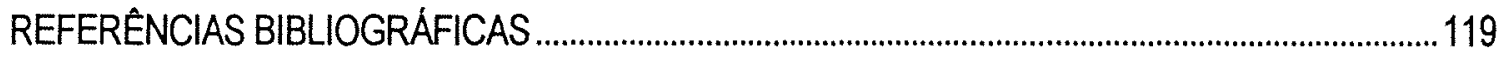

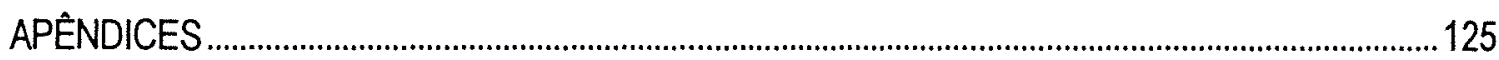




\section{LISTA DE FIGURAS}

Figura 1 - Financiamentos concedidos a produtores e cooperativas pelo Sistema Nacional de Crédito Rural (SNCR), valores constantes em Reais (R\$) a preços de 1995, Brasil, 1969-95 ............................................................................... 


\section{LISTA DE TABELAS}

Tabela 1 - Financiamentos concedidos a produtores e cooperativas pelo Sistema Nacional de Crédito Rural (SNCR), valores constantes em Reais ( $R \$$ ) a preços de 1995, Brasil, 1969-95 ................................................................................7

Tabela 2 - Taxa real de juros do crédito rural, segundo a finalidade do empréstimo, Brasil, 1970-95 …...................................................................................

Tabela 3 - Remuneração do aval e o limite de financiamento nas operações com a Cédula de Produto Rural (CPR) segundo a fase de desenvolvimento do empreendimento

Tabela 4 - Volume total de operaçōes com CM-G, por produto, 1995 39

Tabela 5 - Volume total de operações com CM-G, por segmento de cadeia agroalimentar, 1995

Tabela 6 - Capacidade estática dos armazéns cadastrados no SINAZEM conforme uso e posse, por unidade da federação das grandes regiões selecionadas, Brasil, out/1994. 80

Tabela 7 - Produção agricola de grãos e de fibras, por unidade da federação das grandes regiōes selecionadas, Brasil, safra 1993/94... 
Tabela 8 - Capacidade estática e dinâmica para armazenagem convencional, por

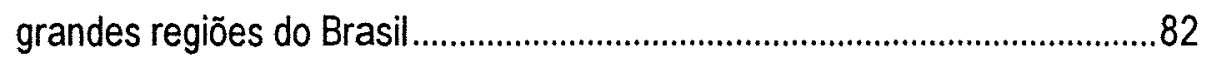

Tabela 9 - Capacidade estática e dinâmica para armazenagem à granel, por grandes

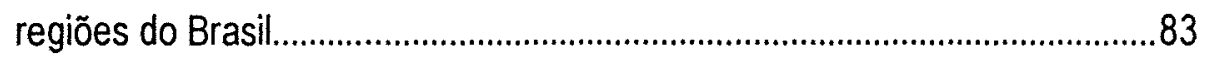

Tabela 10 - Estrutura comparativa básica do CM-G e da CPR.........................................86

Tabela 11 - Resumo das operações com CM-G efetuadas entre 26/07/93 e 31/12/94 ...96

Tabela 12 - Resumo das operações com CM-G, no ano de 1995....................................97

Tabela 13 - Resumo das operações com CPR efetuadas entre ago/94 e 21/10/96 _........97

Tabela 14 - $\quad$ Aquisição e ứlização da soja pelo setor moageiro, 1992-1994 .....................99

Tabela 15 - Descrição da operação 1: custeio de soja não irrigada, região de Assis, safra 1994/95. 102

Tabela 16 - Descrição da operação 2: custeio de soja não irrigada, região de Assis, safra 1995/96. 103

Tabela17 - Descrição da operação 3: custeio de soja não irrigada, região de Assis, safra 1996/97. .104 
Tabela 18 - Preço futuro da soja na Bolsa de Chicago (CBOT) decomposto para pagamento antecipado através da CPR e do CMFG. 106

Tabela 19 - Taxa de desconto na decomposição do preço futuro da soja FOB/Paranaguá (PFOBPAR) para valor liquido da CPR(MiqCPR)..............108

Tabela 20 - Taxa de desconto na decomposição do preço futuro da soja FOB/Paranaguá (PFOBPAR) para valor líquido do CMFG (VliqCMFG)......109

Tabela 21 - Equivalente sacas dos recursos necessários para custeio de soja de acordo com os contratos CPR, CMFG e SNCR e variação com relação ao $E_{S N C R}$ 


\title{
O CERTIFICADO DE MERCADORIA COM EMISSÃO GARANTIDA (CM-G) COMO FONTE ALTERNATIVA DE FINANCIAMENTO PARA O SETOR AGROPECUÁRIO
}

\author{
Autora: Terezinha Joyce Fernandes Franca \\ Orientador: Prof. Dr. Joaquim José Martins Guilhoto
}

\section{RESUMO}

O modelo de financiamento do setor agricola, baseado na intervenção governamental, não possui mais possibilidade de sustentação. O próprio governo e as lideranças rurais reconhecem, dentre outras, a necessidade de criação de instrumentos que possam carrear recursos para o financiamento da atividade produtiva, em substituição/complementação ao Estado, e que modernizem a comercialização agrícola. Como consequêencia, os setores envolvidos têm buscado novas soluções e algumas propostas têm sido defendidas como saidas para o problema de como financiar a agricultura.

Neste contexto, sob a perspectiva de que o setor rural necessita de maior independência do dinheiro oficial e que o desenvolvimento da agricultura, numa economia de mercado, deva contar com a participação do setor privado no financiamento de suas atividades, foram criados titulos para o setor rural e, dentre eles, o Certificado de Mercadoria com Emissão Garantida (CM-G).

O presente estudo tem como objetivo geral examinar a viabilidade do CM-G ser um instrumento alternativo e/ou complementar de financiamento da agricultura para as finalidades de custeio $e$ comercialização./Especificamente descreve-se a estrutura que dá suporte às duas modalidades do CM-G - entrega fisica futura garantida - CMFG, e entrega fisica disponivel garantida - CMDG. Efetuouse também a análise comparativa das caracteristicas do CM-G com relação à outros titulos que também se propõe à comercialização antecipada dos produtos agricolas para alavancagem de capital, com ênfase à Cédula de Produto Rural (CPR). Diante da característica de incerteza do processo de 
produção agricola e da importância que os custos financeiros envolvidos na obtenção de recursos para financiamento representam para o empreendimento rural, procurou-se determinar comparativamente, através de simulações, qual o custo financeiro envolvido na utilização do CM-G, da CPR e dos contratos tradicionais de crédito, baseados nas normas do Sistema Nacional de Crédito Rural (SNCR) para o custeio de soja, nas safras 94/95, 95/96 e 96/97.

O Certificado de Mercadoria com Emissão Garantida (CM-G) foi o primeiro título com real garantia de entrega fisica da mercadoria e possibilidade de obtenção de recursos. É um titulo cuja natureza juridica é a de um contrato mercantil de compra e venda de mercadorias. Voltado para o mercado físico, constituiu-se num avanço às modalidades de negociação existentes, pois compõe um sistema de negociação no qual os riscos tão comuns às operações nesse mercado são reduzidos, devido ao papel que a bolsa de mercadorias e cereais, a câmara de compensação de negócios (clearing house), o sistema de seguros e a armazenagem desempenham na viabilização do certificado, constituindo o sistema de negociação do CM-G. Esse sistema, que envolve também os bancos como prestadores de fiança e registradores do certificado na clearing, e que garantem o cumprimento do contrato, foi concebido para fazer interagir, cada um com sua função, os vários setores que atuam nesse sistema de comercialização de produtos agricolas.

O elo de ligação entre os agentes é a câmara de compensação de negócios (clearing house), cujo objetivo social é o registro, a compensação, a administração das garantias e a liqujdação dos negócios. No cumprimento desses objetivos, torna-se o principal agente garantidor do sistema e, consequentemente, o principal responsável pela redução do risco de inadimplência, de ambas as partes, nas negociações do mercado físico através do CM-G. $O$ fortalecimento desse mercado, através do aumento de credibilidade das operações, dá respaldo às operações no mercado de futuros, contribuindo para o seu crescimento e desenvolvimento.

A partir das simulações efetuadas pode-se concluir que as operações com a CPR e 0 CMFG trariam resultados de receitas semelhantes para o produtor, envolvendo taxas de descontos bastante elevadas. Por outro lado, os recursos obtidos através do SNCR são os que per- 
mitiram o menor custo financeiro no custeio da safra e, portanto, a maior receita, mesmo na safra 1994/95, quando ainda eram corrigidos pela TR mais juros.

O mercado de titulos agricolas no Brasil, apesar de incipiente, foi bastante estimulado a partir do inicio das operações com o CM-G e a CPR. Reforçado pela mudança na condução da política agricola que vem sendo implementada em direção à privatização dos financiamentos, principalmente de custeio e comercialização, esse mercado tende a se desenvolver e se consolidar, estimulando também o crescimento do mercado secundário de titulos, tornando o setor agricola capaz de auto financiar-se. 


\section{THE ISSUED GUARANTIED MERCHANDISE CERTIFICATE (CM-G) AS AN ALTERNATIVE SOURCE OF FINANCING FOR THE AGRICULTURAL SECTOR}

Author: Terezinha Joyce Fernandes Franca Adviser: Prof. Dr. Joaquim José Martins Guilhoto

\section{SUMMARY}

The current agricultural financing model, based on government intervention, cannot be supported anymore. The government and the rural leaderships recognize the need for new financing tools, to modernize the trade of agricultural commodities. The proposal of a new bond for the rural sector brings more independence from public resources, relying more on the society.

The main objective of this study is to examine the feasibility of the Issued Guaranteed Merchandise Certificate (Certificado de Mercadoria Com Emissão Garantida - CM-G) being an alternative and or a complementary instrument to finance agricultural production and trade. Specifically, it describes the structure that gives support to both models of CM-G: Guaranteed Future Delivery - CMFG, and Available Physical Delivery Guaranteed - CMDG. It has also been made the comparative analysis of the CM-G with a similar paper: Cédula de Produto Rural (CPR).

Considering the uncertainty that surrounds agricultural production and the impact that the cost of money has on the economic situation of the rural enterprise; this study tries to compare, using simulations, what is the financial cost involved on operations with CM-G, CPR and the traditional credit contracts. The calculations are based on the rules of the National Rural Credit System (Sistema Nacional de Crédito Rural - SNCR) on the cost of soybean, on the 94/95, 95/96 and $96 / 97$ crops. 
The Issued Guaranteed Merchandise Certificate was the first paper with real physical delivery. It is classified by law as a buy / sell merchandise contract. Aimed to the physical market, it brings an evolution because it reduces the risk, associated with this market. This is due to the merchandise and cereals' board of trade, the clearing house, the insurance and storage system. The banks play an important role in the system since they act as guarantor, as certificate registrar at the clearing house, and as responsable for the carrying out of the contract.

The link between the agents is the clearing house. Its social objective is the registration, the compensation, the collaterals administration, as well as evening up the operation. Accomplishing these objectives makes the clearing house the main responsible for the reduction default on both sides of the CM-G physical market. The strengthening of this market contributes to the growth and development of future markets.

The simulation shows that the operations with CPR and CMFG have similar impact on the producer's income and are associated with high discount rate. The resources obtained by SNCR are the least expensive, and therefore is associated with the larger income. This is true even on the 1994/95 crop, when it was adjusted by TR plus the interest rate.

The market of agricultural papers in Brazil, although incipient, was very stimulated by the operations with the CM-G and the CPR. The new agricultural policy is oriented to private financing. This market tends to develop and consolidate, stimulating the growth of the secondary titles market, increasing the agricultural sector capacity to finance itself. 


\section{INTRODUÇÃO}

O processo de aceleração inflacionária aliado à crise fiscal e financeira do Governo Federal, principalmente a partir de meados da década de oitenta, limitaram gradualmente a capacidade do Estado em transferir renda e, conseqüentemente, de coordenar as políticas setoriais. Tais fatores foram as principais causas da desestruturação do sistema de financiamento da agricultura, o qual, calcado principalmente nas fontes tradicionais de recursos, regidas pelo Sistema Nacional de Crédito Rural (SNCR), e baseado na intervenção governamental', deixou de atender adequadamente às necessidades do setor.

Entre os agentes econômicos que participam direta ou indiretamente das atividades do setor agrícola, tais como as entidades de classe, o governo, os pesquisadores, o setor financeiro (bancos, bolsas, corretoras), as agroindústrias, cooperativas de produção e de crédito, produtores, entre outros, há um certo consenso ${ }^{2}$ de que este sistema não é mais capaz de prover recursos compativeis com as necessidades de uma agricultura moderna, intensiva no uso de insumos e, portanto, altamente dependente de crédito, seja para investimento ou capital de giro.

Diante desta situação, o setor privado buscou alternativas e gerou mecanismos criativos para atender a agricultura. Entre estas alternativas estão os certificados e contratos lastreados em produtos. O Certificado de Mercadoria com Emissão Garantida (CM-G), é um desses mecanismos. É um título mercantil de contrato de compra e venda, disponivel nas modalidades entrega física futura garantida CMFG, e entrega física disponivel garantida - CMDG.

1 Relaciona-se ao grau de regulamentação do crédito rural através dos sistemas de controle de juros e dos recursos, por meio dos juros institucionalmente fixados e a obrigatoriedade das exigibilidades, bem como, a ingerência do governo nos mercados agricolas, como as importaçōes concessionais, o controle de preços e a venda de estoques públicos sem regras pré-definidas, afastando o setor privado do mercado de estoques.

2 A incapacidade do Sistema Nacional de Crédito Rural em atender completamente as necessidades da agricullura foi ponto de consenso nos 
O presente estudo tem como objetivo principal descrever e analisar o Certificado de Mercadoria com Emissão Garantida (CM-G), considerando sua possibilidade de uso como instrumento alternativo e/ou complementar de crédito.

O CM-G após um grande número de operações efetuadas a partir do seu lançamento no ano de 1993, com crescimento continuo até 1995 e evolução irregular com operações eventuais a partir de 1996, fato que será abordado ao longo deste estudo. No entanto, a importância desta pesquisa se mantém na medida em que o registo da experiência de desenvolvimento do $C M-G$, um dos poucos títulos agricolas utilizados pelo mercado até o momento, com certeza poderá contribuir para adequar e aperfeiçoar novas propostas de instrumentos de financiamento destinados ao mercado fisico.

\subsection{Delimitação do problema de pesquisa}

A pesquisa desenvolvida procura responder as seguintes questões básicas:

- Qual a natureza do esgotamento do sistema de crédito rural? Este poderia ser substituído Icomplementado por algumas novas formas de financiamento com recursos do setor privado?

- Quais seriam algumas dessas formas alternativas de financiamento da agricultura?

- Dentre essas formas, o Certificado de Mercadoria com Emissão Garantida (CM-G) é um instrumento viável?

\subsubsection{O esgotamento do Sistema Nacional de Crédito Rural (SNCR)}

Este item apresenta considerações sobre o financiamento da agricultura nas três últimas décadas, bem como as principais causas do seu esgotamento. 
O desenvolvimento da agricultura em economias de mercado depende da existência simultât nea de alguns instrumentos fundamentais, entre eles o crédito rural, que tem como função prover recursos para o financiamento das diversas fases da produção, a custos e prazos compativeis com as características da agricultura ${ }^{3}$.

No Brasil, o crédito rural tem sido, desde a criação do Sistema Nacional de Crédito Rural (SNCR), um dos principais instrumentos da politica agricola nacional. Porém, diante da necessidade de redução dos gastos do governo na busca do ajuste fiscal e da redefinição do papel do Estado na economia em direção à liberalização, este instrumento carece de formas alternativas capazes de responder às necessidades do setor.

Como conseqüência, a agricultura que, durante a década de setenta contou com recursos abundantes a taxas de juros reais negativas para o seu financiamento, a partir da década de oitenta, com a incorporação gradativa da correção monetária aos valores emprestados via SNCR, passou a conviver com volumes reduzidos e taxas de juros reais tendendo a positivas, com a eliminação dos subsidios, notadamente, a partir dos anos noventa.

A evolução da agricultura brasileira, principalmente entre meados da década de $60 \mathrm{e}$ final da década de 70, baseou-se numa estratégia de modernização apoiada em quato pontos principais:

1. maior abertura ao comércio internacional;

2. forte expansão dos programas de crédito subsidiado;

3. aumento dos gastos com extensão rural;

4. um especial tratamento do setor de insumos - tratores, fertilizantes, inseticidas e herbicidas (Mendonça de Barros ${ }^{4}$, citado por CARVALHO, 1986).

3 O financiamento da agricultura oferece diferentes problemas quando comparado com outros tipos de negócios. "Os sistemas de produçăo na agricultura exigem períodos de lempos variáveis. Enquanto a indústria, uma vez tendo sua capacidade de produção instalada, pode apresentar uma produçăo uniforme, continua e diária, a agricultura obedece condiçōes impostas pela natureza, com periodos de safra e entresafra $e$, a defasagem entre investimentos e custos, e as receitas se distanciam, quanto mais demorado é o processo de maturaçăo da exploração. Assim, a lenta recuperação do capital na agricultura nảo significa que a agricultura é ineficiente mas que os problemas administrativos da unidade de produção, no que se refere ao uso dos fatores de produção - capilal, trabalho e terra, diferem muito das indústrias não agricolas. Isto implica que os problemas de crédito e financiamento da agricultura devem receber um tratamento diferenciado em relação ao setor urbano-industrial" (NEVES, 1987, p. 12).

4 MENDONÇA DE BARROS, José R. Poilitica de desenvolvimento agrícola no Brasil. São Paulo, IPENSP, 1982. 36p. (Trabalho para Discussão Interna, 16/82). 
Através dessas medidas de politica buscavarse "a criação de condições que dessem suporte ao crescimento urbano. Neste sentido, maior produtividade, menores preços de alimentos e maiores exportações seriam a medida de sucesso da politica" (CARVALHO, 1986, p. 8).

O Sistema Nacional de Crédito Rural (SNCR) surgiu neste contexto. Foi criado pela Lei $n^{\circ} 4.829$ de novembro de 1965 e regulamentado pelo Decreto $n^{\circ} 58.380$ de maio do ano seguinte, tendo como principais objetivos (FAGUNDES, 1987, p. 9):

1. "estimular o incremento dos investimentos rurais, inclusive para amazenagem, beneficiamento e industrialização de produtos agropecuários;

2. favorecer o custeio oportuno e adequado da produção e comercialização de produtos agropecuários;

3. possibilitar o fortalecimento econômico dos produtores rurais, notadamente dos mini, pequenos e médios produtores; $\mathrm{e}$,

4. incentivar a introdução de métodos racionais de produção, visando o aumento da produtividade $e$ melhoria do padrão de vida das populações rurais e adequada defesa do solo ".

SAYAD (1984, p. 94) define como objetivos do novo sistema "incentivar a produção agricola, proteger os pequenos produtores rurais e promover a modernização da agricultura. 0 programa pretendia garantir maior parcela de recursos financeiros para a agricultura, já que os bancos comerciais privados, sem o apoio desta legislação, não a atendiam satisfatoriamente. Além disso, muitos analistas apontavam que um desempenho mais razoável do setor agrícola, quer em termos da produção, quer em termos da produtividade, dependia de oferta mais firme e estável de recursos financeiros. A modernização, em especial, era objeto prioritário da politica de financiamento".

A criação desse sistema insere-se num contexto de alteração da estrutura econômica brasileira. De acordo com DELGADO (1985, p. 11), ficam destacados como elementos significativos dessa mudança "as transformações que se operam no conjunto da sociedade, com crescimento rápido da urbanização e do comércio exterior agrícola, mudança na base técnica de produção rural e consolidação simultânea de um sistema nacional de crédito rural, que apoia e potencia a realização desse projeto" de modernização. 
A politica de crédito rural foi o carro-chefe da modernização do setor agropecuário na medida em que financiou o conjunto do setor agricola e não somente os setores ligados ao modelo primárioexportador. A politica praticada anteriormente, era formulada, basicamente, por intermédio dos institutos isolados de produto, como o Instituto Brasileiro do Café, Instituto do Açúcar e do Álcool e Comissão Especial da Lavoura Cacaueira.

DELGADO (1985) ressalta que o SNCR, concebido para induzir e promover a mudança na base técnica da agricultura, viabilizou a constituição do complexo agroindustrial, ou seja, contribuiu para o crescimento da relação agricultura-indústria com o desenvolvimento de ramos industriais a montante (meios de produção para a agricultura: insumos - fertilizantes, defensivos, corretivos de solo; e bens de capital - tratores, implementos diversos, colhedeiras, equipamentos para irrigação, etc.) e a jusante da agricultura (processamento de produtos agrícolas).

Essa politica foi orientada pela suposição de que a modernização dos processos produtivos exigiria elevação dos gastos com insumos produzidos fora da propriedade, elevando a necessidade de crédito, dificilmente atendida pelos canais financeiros normais. Assim, o SNCR traduziu-se por aportes substanciais de recursos financeiros à disposição do setor já em 1969, ano em que o saldo total de crédito rural atingiu nivel semelhante ao que vem ocorrendo nos anos 90 (Figura 1 e Tabela 1).

Crescendo rapidamente a partir do final da década dos sessenta, o total de recursos aplicados em crédito rural, através do SNCR, alcançou o auge no periodo 1975-82, com volumes de crédito $400 \%$ a $500 \%$ superiores aos de 1969 , em termos reais. Até o inicio dos anos oitenta expandiu-se intensamente a oferta de crédito, tanto os de curto prazo (custeio e comercialização), como os de longo prazo (investimento) com vantagem no ritmo de crescimento para a modalidade de custeio (GATTI et alii, 1993). Os anos 1979 e 1980 se destacam como o periodo de maior oferta de crédito à agricultura, em todas as modalidades, desde a criação do SNCR até hoje. 


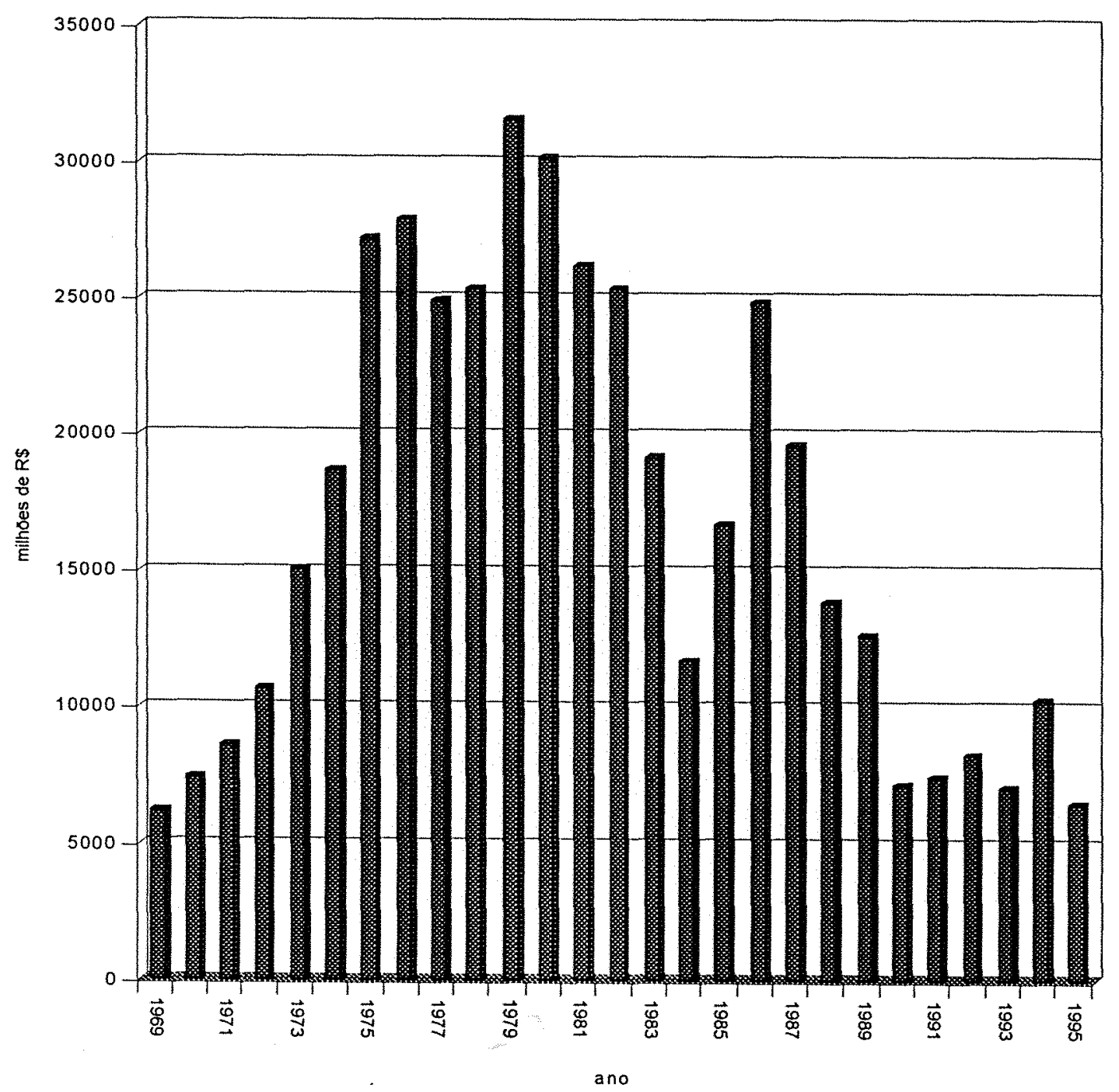

Figura 1 - Financiamentos concedidos a produtores e cooperativas pelo Sistema Nacional de Crédito Rural (SNCR), valores constantes em Reais (R\$) a preços de 1995', Brasil, 1969-95.

Fonte: Banco Central do Brasil (BACEN), Anuário Estatistico de Crédito Rural, 1995.

(') A preços de 1995 - base = Média IGPIDI - FGV no ano 1995. 
Tabela 1 - Financiamentos concedidos a produtores e cooperativas pelo Sistema Nacional de Crédito Rural (SNCR), valores constantes em Reais (R\$) a preços de $1995^{1}$, Brasil, 1969-95.

\begin{tabular}{lcc}
\hline Ano & $\begin{array}{c}\text { Valores Constantes } \\
(\text { R } \$\end{array}$ & $\begin{array}{c}\text { Variação Anual } \\
(\%)\end{array}$ \\
\hline 1969 & $6.251 .370 .764,00$ & - \\
1970 & $7.469 .256 .523,00$ & 19,48 \\
1971 & $8.631 .326 .121,00$ & 15,56 \\
1972 & $10.678 .870 .954,00$ & 23,72 \\
1973 & $15.107 .260 .625,00$ & 41,47 \\
1974 & $18.676 .985 .779,00$ & 23,63 \\
1975 & $27.231 .565 .978,00$ & 45,80 \\
1976 & $27.901 .596 .300,00$ & 2,46 \\
1977 & $24.911 .454 .870,00$ & $(10,72)$ \\
1978 & $25.328 .499 .741,00$ & 1,67 \\
1979 & $31.565 .334 .166,00$ & 24,62 \\
1980 & $30.187 .056 .591,00$ & $(4,37)$ \\
1981 & $26.183 .087 .176,00$ & $(13,26)$ \\
1982 & $25.354 .943 .375,00$ & $(3,16)$ \\
1983 & $19.139 .709 .538,00$ & $(24,51)$ \\
1984 & $11.690 .724 .305,00$ & $(38,92)$ \\
1985 & $16.671 .109 .949,00$ & 42,60 \\
1986 & $24.859 .561 .542,00$ & 49,12 \\
1987 & $19.596 .843 .563,00$ & $(21,17)$ \\
1988 & $13.828 .566 .388,00$ & $(29,43)$ \\
1989 & $12.626 .548 .541,00$ & $(8,69)$ \\
1990 & $7.214 .310 .578,00$ & $(42,86)$ \\
1991 & $7.443 .122 .771,00$ & 3,17 \\
1992 & $8.252 .804 .766,00$ & 10,88 \\
1993 & $7.087 .335 .347,00$ & $(14,12)$ \\
1994 & $10.239 .484 .137,00$ & 44,48 \\
1995 & $6.481 .597 .114,00$ & $(36,70)$ \\
\hline
\end{tabular}

Fonte: Banco Central do Brasil (BACEN), Anuário Estatistico de Crédito Rural, 1995.

(1) A preços de 1995 - base = Média IGPIDI - FGV no ano 1995. 
A década dos setenta foi, portanto, um periodo de vastos recursos disponiveis oriundos, basicamente, do Tesouro Nacional, período em que o Governo Federal adotou uma política de orçamento em aberto para a agricultura.

0 excesso de recursos postos à disposição do setor rural em relação às suas reais necessidades de financiamento ficou evidente nos anos 70 , acarretando a baixa eficácia do crédito rural em termos de seu impacto na produção. 0 volume de crédito rural ao longo desta década mais que quadruplicou em termos reais, o que não ocorreu com a produção. Esse fato ocultava o real problema dos desvios a que eram submetidos os recursos altamente subsidiados (SOBOLL, 1993).

A crescente oferta de recursos de crédito para a agricultura ao longo daquela década foi acompanhada por subsidios também crescentes, como resultado da manutenção dos juros nominais do crédito rural em niveis constantes, enquanto elevavam-se as taxas de inflação da economia. Ou seja, a combinação desses fatores produziu taxas reais de juros negativas, como demonstrado na $\mathrm{Ta}$ bela 2, implicando, portanto, em taxas fortemente subsidiadas (ALMEIDA \& FRANCA, 1993). 
Tabela 2- Taxa real de juros do crédito rural, segundo a finalidade do empréstimo, Brasil, 1970-94'

\begin{tabular}{cccc}
\hline Ano $^{2}$ & & Finalidade & \\
\cline { 2 - 4 } & Custeio & Investimento & Comercialização \\
\hline 1970 & $-1,85$ & $-1,85$ & $-1,85$ \\
1971 & $-2,34$ & $-2,34$ & $-2,34$ \\
1972 & $-0,43$ & $-0,43$ & $-0,43$ \\
1973 & $-0,61$ & $-0,61$ & $-0,61$ \\
1974 & $-14,50$ & $-14,50$ & $-14,50$ \\
1975 & $-11,13$ & $-11,13$ & $-11,13$ \\
1976 & $-21,34$ & $-21,34$ & $-21,34$ \\
1977 & $-17,15$ & $-14,99$ & $-14,99$ \\
1978 & $-18,32$ & $-16,19$ & $-16,19$ \\
1979 & $-35,10$ & $-31,72$ & $-31,72$ \\
1980 & $-36,76$ & $-34,38$ & $-38,66$ \\
1981 & $-25,72$ & $-25,72$ & $-25,72$ \\
1982 & $-27,39$ & $-13,92$ & $-27,39$ \\
1983 & $-30,13$ & $-9,45$ & $-30,13$ \\
1984 & 0,93 & 0,93 & 0,93 \\
1985 & $-1,34$ & $-1,34$ & $-1,34$ \\
1986 & $-35,45$ & $-35,45$ & $-35,45$ \\
1987 & 2,10 & 2,10 & 2,10 \\
1988 & $-10,85$ & $-10,85$ & $-10,85$ \\
1989 & $-46,00$ & $-46,00$ & $-46,00$ \\
1990 & $-12,72$ & $-12,72$ & $-12,72$ \\
1991 & 10,69 & 10,69 & 10,69 \\
1992 & 11,35 & 11,35 & 1,35 \\
1993 & 2,69 & 2,69 & 13,11 \\
1994 & $-3,19$ & $-3,19$ & 13,11 \\
1995 & 13,11 & -19 & \\
1970 & $1988 ;$ & & \\
\hline
\end{tabular}

Fonte: $1970 / 1986$ - SHIROTA (1988); 1987/1995 - cálculos da pesquisa utilizando a mesma metodologia de SHIROTA (1988).

'Considerando-se empréstimos para médios produtores do Centro-Sul; no periodo 1987 a 1995 cálculos para recursos oriundos das exigibilidades.

${ }^{2}$ Para o cálculo utilizou-se o IGP-DI/FGV (variação entre dezembro e dezembro de cada ano). 
$\mathrm{Na}$ década de oitenta iniciase um período de mudança na condução da política agrícola. $\mathrm{O}$ crédito rural, importante instrumento pró-modernização, passou a sofrer fortes restrições. De um lado, pela diminuição do volume de recursos disponiveis para o financiamento da agricultura que atingiu, num primeiro momento, o crédito de investimento e comercialização. De outro, pela redução dos subsídios através da elevação dos encargos financeiros, via aumento gradual, mas continuo, da taxa de juros e da indexação dos empréstimos à correção monetária.

Tais restrições ao crédito derivaram-se da crise dos anos oitenta que se iniciou com a recessão de 1982/83, do agravamento do problema da divida externa, do recrudescimento da inflação e do inicio do processo de crise financeira do Estado brasileiro.

A partir do primeiro ano da década de oitenta começa a mudar, também, a composição das fontes de recursos para o setor rural. O Governo que atuava majoritariamente na aplicação em crédito rural via Tesouro Nacional, reduz sua participação na oferta de crédito através de aumentos, cada vez mais freqüentes, dos percentuais de exigibilidade sobre os depósitos bancários. Instalou-se portanto, um quadro restritivo em relação à politica de financiamento para a agricultura que se concretizou na redução dos recursos disponiveis e numa tentativa de racionalização da oferta de crédito.

Neste ponto é importante a abordagem da questão dos subsidios. As justificativas para a adoção de subsidios no crédito rural, ou seja, financiamentos para a agricultura a taxas de juros reais negativas, seriam (FAGUNDES, 1987, p. 70):

- " baixa rentabilidade do setor que o impediria de pagar taxas de juros de mercado;

- taxas cambiais sobrevalorizadas que penalizam suas exportações;

- controle generalizado dos preços dos alimentos (cesta básica dos trabalhadores); e,

- desvantagens naturais, entre outas".

No entanto, segundo SAYAD (1984) vários são os problemas acarretados pelo crédito rural subsidiado, entre eles: 
- a ineficiência para estimular o crescimento da produção agropecuária, na medida em que, sendo o capital fungivel, leva os produtores a substituírem os recursos próprios, que seriam desviados para atividades mais rentáveis em outos setores da economia, por recursos financeiros subsidiados. 0 crédito, neste caso, estaria apenas substituindo recursos próprios e não colaborando com mais recursos para a atividade meta;

- o poder concentrador de renda e de riqueza, na medida em que são os que detêm maior quantidade de terras que dele se beneficiariam. Esse perfil de distribuição de crédito estaria vinculado à prática bancária de beneficiar tomadores que apresentem menor risco de inadimplência frente às taxas de juros praticadas e forneçam garantias reais (terras, imóveis, etc.) como contrapartida dos empréstimos; e,

- as pressões sobre as contas do governo, visto que os subsidios implicitos no crédito rural, por impossibilitarem a recomposição do valor real financiado e a manutenção dos empréstimos para a safra seguinte teriam que ser supridos, na sua diferença, por recursos governamentais, ocasionando aumento da base monetária e da liquidez, acarretando maior inflação.

Desta forma, se por um lado a politica de crédito adotada através do Sistema Nacional de Crédito Rural (SNCR) cumpriu um importante papel na modernizaçãa ${ }^{5} \mathrm{e}$ crescimento do setor agricola, e contribuiu significativamente para a consolidação do complexo agroindustrial, por outro, o subsidio ao crédito trouxe problemas como o desestímulo à ưtilização de capital próprio (acarretando a substituição do mesmo pelo crédito subsidiado e não um incremento de recursos para a agricultura), o poder concentrador de renda e de riqueza, bem como as pressões inflacionárias causadas pela utilização de recursos do governo na equalização das taxas cobradas no crédito subsidiado frente às taxas de captação.

No entanto, se nas últimas três décadas a atuação da politica de crédito rural teve um importante papel na tansformação da agricultura brasileira, atualmente é quase impensável voltar a ter créditos abundantes financiados com recursos do Tesouro Nacional e, da mesma forma, a volta dos sub-

\footnotetext{
5 A modernizaçāo da agricultura brasileira segundo DELGADO (1985, p. 11) é conservadora pois "mantém intocável a estrutura da propriedade territorial, sancionando-a como base de integração e valorização junto ao sisterna de crédito, e fonte de obtençāo de financiamentos em condiçøes favorecidas de juros, prazos e carências".
} 
sidios crediticios nos niveis e volumes anteriormente observados. Portanto, a questão central do financiamento da agricultura está exatamente na viabilidade de novas fontes e instrumentos de captação de recursos.

Segundo SOBOLL (1993), o financiamento da produção é muito mais amplo do que o crédito rural, exigindo o conhecimento dos fluxos financeiros nos momentos que precedem e sucedem a produção propriamente dita, implicando desde a comercialização de insumos necessários à produção, até a rede de distribuição de produtos industrializados com origem no setor agropecuário. A base deste sistema reside no entendimento entre os agentes do setor privado, nos segmentos representados pelo setor de insumos (quimicos, genéticos e/ou mecânicos), pelos produtores (associações, cooperativas, sindicatos), pelos formadores do mercado fisico (comerciantes, corretores, bolsas de mercadorias ou de cereais), pelos transformadores dos produtos primários (indústrias de alimentos e exportadores tradings) e pelo mercado financeiro (agentes financeiros, mercados futuros, Fundos de Commodities, seguradoras).

É nesse contexto que este estudo se insere, na medida em que tem como principal objetivo descrever e analisar o Certificado de Mercadoria com Emissão Garantida (CM-G), considerando sua possibilidade de uso como instrumento alternativo e/ou complementar de crédito.

\subsubsection{Novos instrumentos de captação de recursos para a agricultura}

Este item relaciona algumas propostas sugeridas como alternativas para financiar a agricultura. De acordo com a análise anterior, fica claro que um dos principais problemas enfrentados pela setor agrícola é o de como se financiar. Os estudiosos do assunto têm muitas propostas. Entre elas, destacam-se as citadas a seguir. 
Cooperativismo de crédito

O desenvolvimento do cooperativismo de crédito, independente e gerido pelo próprio setor agricola, através da transformação das Cooperativas de Crédito em pequenos bancos de crédito cooperativo, integrados numa rede nacional, através de um Banco Federal de Crédito Cooperativo, criado e controlado pelas Cooperativas Agricolas, supervisionado e fiscalizado pelo Banco Central. Pressupõ-se que estes bancos cooperativos venham a ser geridos com menores custos operacionais (NAKANO, 1992; MIGUEL, 1992; SOARES, 1992).

A implantação dessa proposta se iniciou com a formação do Banco Cooperativo Sicred S/A (Bansicred) no Rio Grande do Sul, em junho/96. Primeiro banco privado do setor a operar no país, é composto por 54 cooperativas de crédito, está presente em 211 municipios daquele estado, administra recursos da ordem de quarenta milhões de reais e tem capital de $R \$ 8,6$ milhões. Para o início de 1997 está prevista a entrada em operação do Banco Cooperativo do Paraná, com subscrição de capital de $R \$ 8$ milhões, o minimo permitido ${ }^{6}$.

\section{Acão combinada dos mercados formais e informais ${ }^{7}$}

A possibilidade da ação combinada dos mercados formais e informais no financiamento da agricultura, principalmente se voltarem as altas taxas de inflação, que encarecem os recursos obtidos no mercado formal.

Dentre as operaçōes financeiras informais, pode-se citar "quatro tipos bastante comuns entre os agricultores: a) empréstimos em dinheiro obtidos fora do sistema bancário, ou seja, de particulares ou firmas ligados à atividade agropecuária; b) operações de escambo do tipo insumo/produto ou serviço/produto, realizadas entre fornecedores de insumos/serviços e produtores rurais; c) compras e/ou

- Produtor cria banco de crédito, Gazela Mercantil, 23/10/96, p. B17.

"Considere-se crédito fural formal o empréstimo efetuado pelas instituiçōes do sistema financeiro, no âmbito do Sistema Nacional de Crédito Rural e sob o controle direto do governo. Diante dessa definiçăo, pode-se estabelecer que as formas de financiamento realizadas fora do sistema financeiro e não previstas pelo SNCR e fora do controle governamental, são consideradas informais" (segundo Araújo \& Almeicta, 1992, citado por ALMEIDA \& FRANCA, 1993). 
vendas antecipadas de produção, realizadas entre produtores e comerciantes ou beneficiadores de produto agricola; e d) poupança e empréstimos realizados por grupos de poupança ou associações de poupança e crédito rotativos, organizados pelos próprios agricultores" (ALMEIDA \& FRANCA, 1993).

As fontes informais de crédito são vantajosas, principalmente, quando se considera a rigidez e a excessiva burocracia do sistema financeiro formal. Outa característica relevante do crédito informal é oferecer oportunidades de obtenção de recursos, consideradas as devidas limitações, para os diversos niveis de agricultores (ARAÚJO \& ALMEIDA, 1992).

\section{Mecanismos de pré-financiamento à exportação e a comercialização interna}

Os mecanismos de pré-financiamento à exportação e a comercialização interna, bem como de adiantamentos sobre mercadorias depositadas em armazéns gerais ou nas fazendas, a cargo do mercado (NÓBREGA, 1992) como o Adiantamento do Contrato de Câmbio (ACC). De acordo com CAFFAGNI (1994), ACC "é um financiamento dado exclusivamente à exportadores que já tenham a exportação contratada. 0 fornecedor de crédito é um banco que cobra a correção cambial mais uma taxa de juros de $16 \%$ a $18 \%$ ao ano, cuja garantia é o contrato de entrega entre o exportador e o importador. $O$ banco receberá o valor da compra diretamente do importador, visto que ele já forneceu crédito para o exportador. Neste financiamento o exportador recebe 0 dinheiro antes e muitas vezes repassa ao produtor rural comprando seu produto antecipadamente, ou aplica no mercado financeiro. Caso o exportador não consiga realizar o embarque será cobrado uma multa, ou o exportador deverá efetuar uma performance que é a compra do embarque de terceiros".

\section{Certificados rurais}

A criação de certificados rurais, com o objetivo de compatibilizar não só ativos e passivos dos setores rural e financeiro, mas também diluir riscos de preços de produtos agropecuários. 0 principio consiste em repassar riscos de oscilações de preços de produtos para investidores que desejarem carregar seus patimônios no tempo em ativos reais (BARROS, 1991). Ao vender para recebimento a 
vista e entrega futura o produtor fixa o preço do seu produto. Estes contratos podem ser negociados em sistema de bolsa ou através de operações de balcão.

A particularidade desses contratos consiste na possibilidade de os produtores e os demais agentes de mercado poderem comercializar produtos de origem e qualidade diferenciadas, num contrato padrão (SOBOLL, "s.n.t"). A seguir, serão apresentadas de forma sucinta alguns destes papéis que surgiram da criatividade do setor privado como alternativa para substituir formas tradicionais de financiamento com recursos públicos.

Contrato Soja Verde - Contrato ANEC

O contrato soja verde (LOPES, 1994C) é um contrato mercantil dentro dos códigos comercial e civil, para entrega futura de mercadoria. Tem como objetivo o adiantamento de recursos para o custeio, mas pode também ser utilizado para obter insumos, sementes e fertilizantes, através da troca de mercadorias. Este sistema é mais utilizado entre produtores e suas cooperativas. O produtor/vendedor se obriga a entregar determinada quantidade de produto, em data e local preestabelecido, segundo especificações de maturação, teor de umidade, impureza e percentual de quebrados.

Criado pela Associação Nacional dos Exportadores de Cereais (ANEC), deve ter como ga rantias a fiança prestada por empresa, penhor agrícola e garantias reais pignoratícias de primeiro grau, hipoteca e outras garantias livremente pactuadas (inclusive nota promissória). Não está ligado a nenhum sistema de registro ou liquidação, dificultando o controle sobre o emitente.

Esses contratos foram muito utilizados nos anos 1990-93 (SCHOUCHANA, s.d. "a"). Na safra 1993/94, o mecanismo soja verde foi responsável por quase um terço da comercialização total de soja no pais, mas apresentou sérios problemas de inadimplência (não entrega da produção efetjvamente negociada), o que acabou reduzindo sua participação no total comercializado, na safra 1994/95, para menos de 10\% (CANZIANI, 1995). 
Cédula de Produto Rural - $\mathrm{CPR}^{8}$

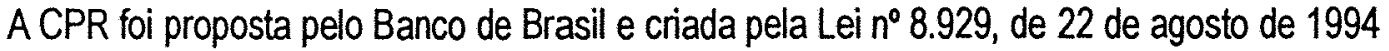
(BRASIL, 1994). É um titulo civil, liquido e certo, endossável (com cláusula "a ordem") e exigivel pela quantidade e qualidade do produto nela previsto ${ }^{9}$. Disponivel apenas na versão "futura", permite a alavancagem de capital de giro necessário ao desenvolvimento da atividade rural. Destina-se à formalização de promessa de compra e venda de produtos rurais para a entrega futura, constituindo-se na promessa de entrega do produto, com ou sem garantia cedularmente constituida. $O$ vendedor se obriga a entregar o produto prometido à venda, segundo descrição, condições, data e local previstos no titulo. ACPR poderá, adicionalmente, conter cláusulas ajustadas entre o vendedor e o comprador. Sua emissão é restrita ao produtor rural e suas associações, inclusive cooperativas, destinando-se exclusivamente a produtos rurais.

Inspirada nas cédulas de crédito rural e industrial, está sujeita às normas do direito cambial, inclusive quanto a aval, dispensando porém o protesto para assegurar o direito de regresso contra endossantes e seus avalistas. A CPR admite como garantias: hipoteca (imóveis rurais e urbanos), penhor (bens suscetiveis de penhor rural e de penhor mercantil, bem como os bens suscetiveis de penhor cedular) e alienação fiduciária. Os bens vinculados à CPR não serão penhorados ou seqüestra dos por outras dividas do emitente ou do terceiro prestante da garantia real.

O maior volume de CPRs tem sido negociada com garantia do Banco do Brasil através de aval, garantindo a entrega fisica da mercadoria negociada nos prazos estipulados. A remuneração do aval e o limite de financiamento nas operações com a Cédula de Produto Rural variam em função da fase de desenvolvimento do empreendimento. No caso de produtos agricolas, são observadas as taxas mostradas na Tabela 3.

- As informações sobre a CPR foram obtidas com base em entrevistas com os técnicos do Banco do Brasil do Grupo de Trabalho BB/CPR, LOPES (1994c) e, NUEVO (1996)

- Os títulos de crédito de nalureza civil são os definidos no Decreto Lei $n^{\circ} .167$, de 14 de fevereiro de 1967, que dispöe sobre os titulos de crédito rural, cujo artigo 10 os define (cédula de crédito rural) como títulos civis, liquidos e certos (p. 300). O endosso é, entre outros, um ins. tituto típico criado pelo direito cambiário. É o meio para se transferir o direito sobre o fitula, ao endossar, o endossador transfere ao endossalário o título e, em consequência, os direitos nele incorporados (p. 339). Os titulos à ordem são os emitidos em favor de pessoa determinada, transferindo-se pelo endosso (p. 309). REQUIĀO, 1988 
Tabela 3 - Remuneração do aval e o limite de financiamento nas operações com a Cédula de Produto Rural (CPR) segundo a fase de desenvolvimento do empreendimento

\begin{tabular}{lcc}
\hline Fases de desenvolvimento da cultura & Taxa do aval & $\begin{array}{c}{ }^{1} \\
\text { Volume financiável da produção } \\
\text { própria estimada }\end{array}$ \\
\hline -no planejamento/implantação & $0,65 \%$ ao mès & até $50 \%$ \\
-após a emergència das plantas & $0,55 \%$ ao mès & até $60 \%$ \\
-na pré-colheita & $0,45 \%$ ao mês & até $70 \%$ \\
\hline
\end{tabular}

Fonte: Banco do Brasil S/A - GT/BB-CPR

${ }^{1}$ Valores nominais.

O volume financiável é calculado com base na produtividade obtida nas últimas safras, ou seja, de acordo com o histórico de produção daquele produtor. De acordo com técnico do Banco do Brasil, dificilmente seria aprovado o aval para um primeiro plantio.

O limite de financiamento estabelecido para cada fase de desenvolvimento da cultura é também cumulativo. Ou seja, novas CPRs podem ser emitidas até atingir o limite previsto em cada fase. 0 valor do aval é calculado sobre o valor total negociado, considerados os meses de vigência.

\section{São requisitos da CPR:}

1. denominação "Cédula de Produto Rural";

2. data e condição de entrega;

3. nome do promissário comprador e cláusula à ordem;

4. descrição do produto objeto da compra e venda;

5. local de entrega;

6. descrição dos bens vinculados em hipoteca, penhor ou alienação fiduciária;

7. data e lugar da emissão; e,

8. assinatura do promitente vendedor emitente. 
A CPR não é necessariamente negociada em bolsa, podendo ser negociada também em "mercado de balcão", o que dificulta o controle do volume efetivo de produtos negociados. No caso da CPR, deve-se salientar que a mesma poderá ser emitida e negociada pelas partes compradora e vendedora que decidirão todas as condições da negociação, entre as quais as garantias a serem exigidas, sem a intermediação de qualquer instituição, apenas respeitando a legislação especifica. A contribuição com relação aos contratos já existentes como, por exemplo, os do setor citricola ou da Associação Nacional dos Exportadores de Cereais (ANEC), se dá na padronização do contrato, que tem registro na Central de Custódia e de Liquidação Financeira de Titulos Privados (CETIP) o que garante que o título tem fé pública.

As primeiras operaçōes com a CPR ocorreram no periodo entre setembro e dezembro de 1994. Foram negociados aproximadamente trinta milhões de reais através de 68 operações, todas elas monitoradas pelo Banco do Brasil. À medida em que a CPR foi sendo mais conhecida, cresceu rapidamente o número de transações, tendo atingido em 21 de outubro de 1996, 1.041 CPRs envolvendo 11 produtos no valor de $R \$ 112.071 .504,02$, principalmente soja em grão - 791 CPRs no valor de $\mathrm{R} \$ 78.676 .923,45$; e, café arábica - 158 CPRs no valor de $\mathrm{R} \$ 8.086 .615,57$; todas avalizadas pelo Banco do Brasil ( Tabela 13, p. 97). No entanto, qualquer outo banco pode operar com a CPR.

\section{Certificado de Mercadoria com Emissão Garantida - CM-G}

O CM-G é um titulo mercantil de contrato de compra e venda, disponivel nas modalidades entrega física futura garantida - CMFG, e entrega fisica disponivel garantida - CMDG. Representa a garantia de entrega e da qualidade do produto oferecido e deve ser negociado nas bolsas de cereais (PANHOCA, 1996).

As operaçōes com o CM-G foram iniciadas a partir de julho de 1993 e evoluiram lentamente até meados de 1994. Deste momento em diante o crescimento passou a ser constante, atingindo em fins de dezembro de 1994 seiscentos e quinze contratos negociados, distribuidos por mais de trinta diferentes produtos, no valor de US\$140 milhöes (Tabela 11, p.96). A partir de janeiro de 1995 os da- 
dos mostraram-se muito mais animadores. Segundo informações da Central de Registros S/A, o volume negociado durante todo 0 ano de 1995, até 31 de dezembro, atingiu US\$ 4,8 bilhões (Tabela 12 , p.97). Desse total, US $\$ 3,7$ bilhões foram de negócios com produtos especificamente agricolas representando $77,63 \%$ do volume total negociado nos vários segmentos da cadeia agroalimentar, de acordo com a classificação de RIBEIRO et alii (1995) (Tabela 5, p.40).

Esse volume de recursos é significativo se comparado ao crédito rural aplicado através do SNCR. Entre 1990 e 1995, o volume de recursos aplicados via este sistema, em valores constantes de 1995, ficou em torno de oito bilhões de reais, tendo superado dez bilhões apenas em 1994, como mencionado anteriormente (Tabela 1, p.7).

A partir de 1996, as operações com o CM-G estão praticamente paralisadas, em parte devido ao processo de esvaziamento da Central de Registros S/A- clearing do sistema que detém o direito de uso e é a única autorizada a operar com o Certificado - após desentendimentos com sua maior acionista, a Bolsa de Cereais de São Paulo. Além disso, outros fatores também contribuiram para a não consolidação desse instrumento. Entre eles a não definição por parte do Governo Federal de uma polifica agricola clara; falta de apoio do mercado industrial e transformador ; e, falta de apoio efetivo das entidades de classes rurais para a organização do mercado. Estas questões serão retomadas no decorrer do estudo.

As propostas acima relacionadas têm motivado o debate em torno da solução aos problemas enfrentados pelo setor agricola que, apesar de muito já ter avançado, ainda está longe de produzir resultados efetivos. Portanto, é com este objetivo que este trabalho se volta a avaliar o $\mathrm{CM}-\mathrm{G}$ com rela ção aos custos, beneficios e viabilidade de implementação. 


\subsection{Objetivos}

O presente estudo tem como objetivo principal descrever e analisar o Certificado de Mercadoria com Emissão Garantida (CM-G), considerando sua possibilidade de uso como instrumento alternativo e/ou complementar de crédito. Como objetivos especificos pretende-se:

1. Descrever a estrutura que dá suporte ao CM-G, de acordo com o papel que as instituições, bolsa de mercadorias e cereais, clearing house, sistema de seguros, e armazenagem, desempenham na viabilização do CM-G.

2. Analisar comparativamente as caracteristicas das normas contratuais do $\mathrm{CM}-\mathrm{G}$ com relação à Cédula de Produto Rural (CPR).

3. Comparar os custos financeiros para o produtor nas safras $1994 / 95,1995 / 96$ e 1996/97 de acordo com a opção feita para a obtenção dos recursos de financiamento para o custeio da produção de soja, através do CM-G, da CPR ou do contrato tradicional de crédito, baseados nas nomas do Sistema Nacional de Crédito Rural (SNCR).

\subsection{Estrutura da pesquisa}

Este estudo subdivide-se em cinco capitulos, além desta introdução que procurou situar a pesquisa dentro do problema do esgotamento do SNCR e, conseqüentemente, da emergência de novas propostas para o financiamento da agricultura. A introdução contém ainda os objetivos.

A metodologia utilizada para a obtenção das informações e simulações efetuadas no estudo é apresentada no segundo capitulo.

O terceiro capitulo descreve o Certificado de Mercadoria com Emissão Garantida, as princi- 
pais caracteristicas e mecanismos operacionais, os objetivos, as vantagens na utilização deste titulo.

O capitulo quarto realiza uma descrição da estrutura (sistema de negociação) que dá suporte ao CM-G, de acordo com os agentes envolvidos e os papéis que desempenham para sua viabilização.

No quinto capitulo realizase análise comparativa das caracteristicas do CM-G em relação à Cédula de Produto Rural (CPR). Também faz-se a avaliação comparativa dos custos financeiros para o produtor ao ufilizar o CM-G para a obtenção de recursos de financiamento em contraposição à CPR e ao financiamento tadicional através do SNCR.

O último capitulo é dedicado às conclusões do estudo. 


\section{METODOLOGIA}

O objeto de estudo desta dissertação, o Certificado de Mercadorias com Emissão Garantida (CM-G), constitui-se em inovação nas áreas de financiamento e comercialização da produção agricola brasileira. Em conjunto com outros papéis, entre eles a Cédula de Produto Rural (CPR), passam a compor o mercado de títulos agricolas no Brasil, ainda muito pouco desenvolvido. Dada a recente criação destes instrumentos, para complementar as informações bibliográicas sobre o assunto, foi ubilizada a análise de informações coletadas através de entrevistas.

Segundo MARCONI \& LAKATOS (1985, p. 70) "a entrevista é o encontro entre duas pessoas a fim de que uma delas obtenha informações a respeito de determinado assunto, mediante uma conversação de natureza profissional. É um procedimento utilizado na investigação social, para a coleta de dados ou para ajudar no diagnóstico ou no tratamento de um problema social".

Neste estudo, a técnica utilizada foi a da entrevista focalizada onde, a partir de um roteiro de tópicos relativos ao problema que se vai estudar, o entrevistador tem a liberdade de fazer as perguntas que quiser, sondando razões e motivos, dando esclarecimentos, não obedecendo, a rigor, a uma estrutura formal, e o entrevistado tem liberdade para desenvolver cada situação em qualquer direção que considere adequada. É uma forma de poder explorar mais amplamente uma questão. Adotando este método, procurou-se contudo, manter a entrevista concentrada nos temas especíicos abordados.

Para MARCONI \& LAKATOS (1985) como técnica de coleta de dados, a entevista oferece várias vantagens e limitações. Como vantagens são citadas: há maior flexibilidade, podendo 0 entrevistador repetir ou esclarecer perguntas; oferece maior oportunidade para avaliar atitudes, condutas, podendo o entrevistado ser observado naquilo que diz e como diz (registro de reações e gestos); dá 
oportunidade para obtenção de dados que não se encontram em fontes documentais e que sejam relevantes e significativos; e, há possibilidade de conseguir informações mais precisas, podendo-se comprovar, de imediato, as discordâncias. As limitações são: dificuldade de expressão e comunicação de ambas as partes; incompreensão, por parte do informante, do significado das perguntas e da pesquisa, que pode levar a uma falsa interpretação; possibilidade do entrevistado ser influenciado, consciente ou inconscientemente pelo questionador, disposição do entrevistado dar as informações necessárias; retenção de alguns dados importantes; pequeno grau de controle sobre uma situação de coleta de dados; e, ocupa muito tempo e é dificil de ser realizada. No entanto, as autoras consideram que estas limitações podem ser superadas ou minimizadas se o pesquisador for uma pessoa com experiência ou tiver muito bom senso.

As entrevistas foram realizadas com pessoas selecionadas segundo a experiência e conhecimento do assunto em questão. Normalmente foi feita uma primeira entrevista exploratória a partir das questões não resolvidas ou mal compreendidas em consulta aos materiais impressos. Em continuida de, novos contatos foram sendo feitos de forma a esclarecer novas dúvidas que foram surgindo. As entrevistas permitiram conhecer melhor os detalhes operacionais, a evolução e os problemas enfrentados na implantação do CM-G e da CPR, visto que a maior parte dessa história recente não foi registrada, tendo sido importantes, também, para compor a descrição dos agentes que participam da estrutura que dá suporte ao CM-G. As entrevistas constituiram-se, portanto, em valioso instrumento para coleta de dados e informações.

Para compor a análise do CM-G, foram feitas simulações, cujo método utilizado será descrito ao longo deste capitulo.

\subsection{Apresentação do material e método utilizados para a descrição dos componentes analisados para a implementação do CM-G}

A seguir serão apresentados como foram realizadas e qual o material utilizado para as descrições do CM-G e da estrutura que lhe dá suporte - bolsa de mercadorias, clearing house, sistema de seguros e de armazenagem - , bem como da CPR. 


\subsubsection{Descrição do $\mathrm{CM}-\mathrm{G}$}

A descrição do $\mathrm{CM}-\mathrm{G}$ foi feita com base em informações obtidas a partir de várias fontes. A maior parte dos materiais impressos utilizados foram produzidos pelos idealizadores deste certificado, os senhores Ademiro Vian, Assessor de Crédito Rural, Operações Bancárias e Contabilidade da Federação Brasileira das Associações de Bancos (FEBRABAN); Heraldo Luiz Panhoca, corretor da Representações Kaưmann Ltda.; Joaquim Antonio de Almeida Prado, notório conhecedor das Bolsas de Mercadorias e do mercado fisico de produtos agricolas; e Paulo Domingues, reconhecido por sua larga experiência de atuação no mercado fisico através das cooperativas de produção; pelos especialistas da Central de Registros S/A, principalmente os senhores Roberto Mauri Cardoso, Administrador de Empresas e Walter Soboll, Engenheiro Agrônomo e ex-Diretor Superintendente da Central de Registros S/A; por vários técnicos das universidades e instituições que se dedicam ao estudo da agricultura como o Prof. Dr. Mauro de Rezende Lopes, Prof. Dr. Pedro Valentim Marques, entre outros; e, para questōes especificas, relativas às caracteristicas dos titulos comerciais, foi consultada literatura especializada sobre direito comercial.

O material produzido pelos autores citados descreve a proposta do CM-G. A Central de Registros S/A produziu: apostilas preparadas por seus técnicos para serem utilizadas em palestras de divulgação do CM-G, proferidas em Bancos, Sindicatos Rurais, Cooperativas, Institutos de Pesquisa, Universidades, entre outros; textos técnicos voltados para a discussão de temas especificos relacionados ao certificado como, por exemplo, Fundo de Commodities, e, as estatisticas referentes às operações efetuadas no periodo de 1993 a 1995. A contibuição da área acadêmica registra-se através de artigos em publicações especializadas.

Para compor a descrição do CM-G foram feitas entrevistas dirigidas aos senhores Ademiro Vian, Heraldo Panhoca, Roberto Mauri Cardoso, Walter Soboll e Leonardo Conversani Filho em várias ocasiōes, pessoalmente ou por telefone. 


\subsubsection{Descrição da estrutura que dá suporte ao $\mathrm{CM}-\mathrm{G}$}

A estrutura que dá suporte ao CM-G, no caso da Bolsa de Mercadorias e Cereais, da clearing house e do sistema de seguros, foi descrita utilizando-se a bibliografia existente, que foi citada ao longo do texto e consta da bibliografia deste estudo, bem como através de entrevistas dirigidas aos senhores citados acima. Com relação ao sistema de seguros foi consultada também, atavés de entevistas a Delgado \& Prada Consultoria e Administração de Seguros, uma das únicas empresas a operarem o Seguro Garantia de Obrigações Contratuais para operações com produtos agricolas no periodo de desenvolvimento desta dissertação. A análise das instituições aqui consideradas foi conduzida de forma a mostrar a importância e a função de cada um desses agentes e como se relacionam de forma a permitir a negociação do CM-G.

A questão da armazenagem foi analisada sob o enfoque das limitações e potencialidades que oferecem para viabilizar a expansão do uso do CM-G. Para tanto, foi necessário um levantamento sobre a estrutura de armazenagem disponivel, numa tentativa de caracterizá-la em termos de localização, capacidade instalada e tipos de unidades armazenadoras. Foram considerados dados e informa ções existentes na bibliografia especializada. Esta análise e levantamento se limitou à região CentroSul e às formas de armazenagem de grãos, visto que este estudo adotou o produto soja como modelo para observação.

\subsubsection{Descrição da CPR}

As informações sobre a CPR foram obtidas, em sua maior parte, junto aos técnicos do Banco do Brasil em São Paulo e junto àqueles que fazem parte do Grupo de Trabalho BB-CPR ${ }^{10}$, em Brasilia. Estes últimos forneceram também cópia do material utilizado para divulgação da CPR, que contém a descrição deste novo instrumento de comercialização, além das estatísticas referentes às operaçōes

10 Este grupo tem o papel de coordenar as operaçöes com a CPR bem com, elaborar estudos e estatisticas, avaliar as operaçöes, criar contralos com no. vos produlos, difundr as regras operacionais, orientar as agências, entre outros. 
efetuadas nos anos 1994, 1995 e 1996. Foram utilizados também trabalhos publicados pelo Prof. Dr. Mauro de Rezende Lopes, Prof. Dr. Pedro Valentim Marques, Walter Soboll e a dissertação de mestrado de Paulo Nuevo (ESALQ/USP, 1996), entre outros. A análise comparativa das características do CM-G com relação a CPR foi realizada a partir das informações obtidas em pesquisa de campo e da bibliografia consultada.

\subsection{Simulações}

Para comparar qual seria o custo financeiro para o produtor de acordo com a opção feita para a obtenção dos recursos de financiamento para o custeio da produção - CMFG, CPR ou contrato tradicional através do SNCR, simulamos contratos equivalentes tomando como base os dados reais contidos nas cédulas rurais pignoraticias, relativos a três diferentes operações de custeio de soja não irrigada, localizadas na região de Assis, São Paulo, para as safras 1994/95, $1995 / 96$ e 1996/97.

A escolha do produto soja ocorreu em função da elevada participação tanto no número de contratos efetuados com o CM-G (Tabelas 11, p.96 e 12, p.97) e com a CPR (Tabela 13, p.97), quanto no valor negociado através desses títulos nos anos de 1994, 1995 e 1996, e também por constituir-se em uma commodity ${ }^{11}$. Determinou também a escolha desse produto a importância que alcança na produção nacional de grãos, concentrada no Centro-Sul, e na pauta de exportações brasileira, bem como ao fato de dar origem a uma cadeia agroalimentar que interliga vários setores como o de produção, comercialização, industrialização e exportação, permitindo visualizar um fluxo de operações com o CM-G nos diferentes niveis desta cadeia.

Por contratos equivalentes entende-se que sejam mantidas as características da operação, inclusive o volume de recursos necessários para o financiamento, mudando apenas a fonte desses recursos. A utilização de recursos próprios foi mantida.

"Significa "mercadoria", em inglês. Nas relaçōes comerciais internacionais, o termo designa um tipo particular de mercadoria em estado bruto ou produto primário de importância comercial como ė o caso do café, do chá, da lā, do algodão, da jula, do estanho, do cobre, etc. Por serem as commodities produtos de grande importancia no comércio internacional, seus preços acabam sendo ditados pelas cotaçōes dos principais mercados (SANDRONl, 1985). 
O contrato tradicional de crédito de custeio, com base nas regras do SNCR, foi escolhido como ponto de partida para a elaboração da comparação devido aos seguintes fatores:

- a disponibilidade de informações reais;

- ao fato do CM-G e da CPR constituirem-se em alternativas a essa fonte de crédito; e,

- a impossibilidade de se obter operações reais cuja fonte de recursos para o custeio fosse 0 contrato tradicional de crédito, O CM-G e a CPR, e que apresentassem as mesmas caracteristicas básicas.

Os dados básicos que compõem o modelo para a descrição das operações consideradas para efeito de simulação dos contratos CMFG e CPR, são os seguintes: produto, região de produção; safra (periodo agricola); periodo do contrato (início e vencimento/liquidação); área plantada (ha); produção esperada ( $\mathrm{kg}$ ); produtividade (kg/ha); volume de recursos (total, financiado e próprios); utilização do crédito; utilização dos recursos próprios; encargos financeiros; saldo liquidado (total, principal, juros e correção); e, receita esperada total.

Para cada operação foram respeitadas as datas de liberação de recursos bem como 0 inicio e o vencimento do contrato (liquidação). Portanto, essas datas foram consideradas como a data de negociação do CM-G e da CPR. A operação de crédito tradicional prevê liberações conforme a necessidade de aplicação de insumos no processo de produção. As negociações via CPR e CM-G são compativeis com essa sistemática, sendo a venda futura parcelada uma oportunidade de se obter uma negociação mais favorável.

Como o CMFG e a CPR antecipam recursos, em primeiro lugar foi necessário obter-se 0 preço provável de negociação desses titulos. $O$ balizamento para esse preço foi obtido a partir das cotações no mercado futuro, onde a formação dos preços acontece de forma competitiva, refletindo a expectativa presente sobre o preço futuro por parte de uma população (segundo Montezano ${ }^{12}$, citado por NUEVO,1996).

12 MONTEZANO, R. M. Introducăo aos mercados futuros de indices de acões. São Paulo, BM\&F/BMEC, 104P., 1987. 
No caso da soja, segundo o que foi apreendido das entrevistas, é comum utilizar-se as cotações da Bolsa de Mercadorias de Chicago (CBOT) (apêndice 1, p.133), como referência de preço. As cotações da Bolsa de Mercadorias e Futuros (BM\&F) poderiam também servir de parâmetro, no entanto não foram utilizadas pois o contrato futuro cambial de soja começou a ser negociado apenas em outubro de 1995 (SCHOUCHANA, s.d. "b"), e o volume negociado ainda não é significativo/Como o pico de safra da soja no Brasil se dá entre março e maio, tomou-se * como referência a cotação futura destes meses, de forma a verificar em que mês seria mais interessante para o produtor o vencimento do contrato.

Na decomposição do preço futuro da CBOT para o mercado interno considerou-se o porto de Paranaguá, local de escoamento para a produção de Assis, São Paulo. Como resultado, foi obtido o preço futuro FOB/Paranaguá (PFOBPAR) (paridade para exportação). Este cálculo consiste em descontar do preço futuro CBOT o Imposto de Circulação de Mercadorias e Serviços (ICMS), fretes, despesas de porto, PIS, taxas e comissões e corretagem de câmbio (a decomposição detalhada para cada uma das operações pode ser verificado nos apêndices 3, p.128; 4, p.129; e 5, p.130). 0 resultado obtido em dólares é transformado para reais utilizando-se a cotação do dia da operação que consta do apêndice 2 (p.127).

No entanto o preço FOB/Paranaguá (PFOBPAR) também é um preço futuro. Para obterse o preço indicativo de negociação da CPR ou CMFG é necessário que sejam efetuados descontos que consistem basicamente: no custo de oportunidade do capital (CK); no custo do aval (Ca) ou fiança (Cf) ou seguro (Cs); e, nos custos de registro em câmara de compensação e de operação em bolsa (Ctx).

Além desses custos, haveria um spread, cobrado pelo comprador do título que adianta os recursos, pelo banco ou fundos de investimento, que consiste numa taxa adicional de risco, variável conforme a liquidez e as garantias do tomador, o volume do empréstimo e o prazo de resgate, e que eleva o custo financeiro final da operação. Nos casos em que são usadas fiança, esse spread estaria refletido na taxa cobrada. Nos casos de aval, também, exceto no Banco do Brasil onde a taxa de aval para a CPR é pré-determinada (como já visto na Tabela 3, p.17). Nas 
operações envolvendo fundos de investimento para carregamento dos títulos, também é possivel a cobrança de um adicional de risco. No entanto, não foi possivel quantificá-lo. Sabe-se, contudo, que com o tempo a competição entre bancos tornará esse spread menor, beneficiando, principalmente o emitente do título.

Com base nas informações obtidas através das entrevistas com os técnicos do Banco do Brasil do Grupo de Trabalho BB/CPR, bem como com os técnicos da Central de Registros S/A, sobre a operacionalização das negociações, respectivamente, com CPRs e CMFGs, foi deduzido que os descontos incidem sobre valores iniciais diferentes.

Ou seja, o valor de negociação $(\mathrm{Vn})$ do título é dado pelo preço futuro FOB/Paranağgú (PFOBPAR) descontado o custo de oportunidade do capital (Ck), porque do ponto de vista do tomador do titulo importa saber qual o valor presente do preço futuro FOB/Paranaguá (PFOBPAR), considerado o custo de oportunidade do capital envolvido. Os outros custos são definidos com base no valor de negociação $(\mathrm{Vn})$ e incidem sobre este, resultando no valor líquido (VliqCPR e VliqCMFG). Assim, do ponto de vista do emitente (produtor) é este último o valor que realmente importa.

\subsubsection{Decomposição do preço FOB/Paranaguá (PFOBPAR) para o valor de negociação da CPR e do CMFG $(\mathrm{Vn})$}

A decomposição do preço futuro FOB/Paranaguá (PFOBPAR) para o valor de negociação da CPR e do CMFG (Vn) foi realizado com base na aplicação do conceito de montante (ou valor futuro) e valor atual (ou valor presente) para pagamento único, sob o regime de capitalização composta. De acordo com VIEIRA SOBRINHO (1982), montante é a soma do capital inicial aplicado ou devido mais os juros correspondentes ao prazo da aplicação ou da divida. Já o valor atual é o valor do capital que, aplicado a dada taxa e a dado prazo, representa o montante conhecido. A fórmula do montante é dada pela equação 1 e dela deduz-se a do valor atual (equação 2): 
$S=P(1+i)^{n}$

$P=\frac{S}{(1+i)^{n}}$

Onde:

$S=$ montante

$P=$ valor atual

$i=$ taxa de juros

$n=$ número de períodos

Este conceito foi utilizado considerando-se que o tomador de um título como o CMFG ou a CPR adianta recursos ao produtor (emissor do título) deixando de utilizá-lo de outras formas. Para tanto, o comprador do título procura otimizar, cobrando do produtor juros equivalentes a taxa da melhor alternativa de aplicação desses recursos, garantindo que seu capital inicial resulte, em tese, no mesmo montante que resultaria se aplicado da forma alternativa.

Neste caso, os juros representam o custo de oportunidade do capital, para o qual foi utilizado a taxa da poupança no mês de liberação dos recursos. Como os período considerados são dados em dias, para a determinação da taxa diária a partir da taxa mensal foi utilizada a conceituação de equivalência de taxas a qual estabelece que duas taxas, referentes a periodos distintos de capitalização, são equivalentes quando produzem o mesmo montante no final de determinado tempo, pela aplicação de um capital inicial de mesmo valor (VIEIRA SOBRINHO, 1982). A equivalência das taxas foi deduzida da equação 3 :

$$
\left(1+i_{m}\right)=\left(1+i_{d}\right)^{30}
$$


Onde:

$i_{m}=$ taxa mensal

$i_{d}=$ taxa diária

A partir dos conceitos citados foi deduzida a fórmula abaixo que foi utilizada para obterse o valor de negociação $(\mathrm{Vn})$ da CPR ou do CMFG.

$V n=\frac{P F O B P A R}{(1+C k)^{N / 30}}$

Onde:

$V n=$ valor de negociação da CPR ou do CM-G.

$P F O B P A R=$ preço futuro FOB Paranaguá na data de liberação dos recursos, base março e maio, em cada uma das operações consideradas

$C k=$ taxa de remuneração da poupança do mês de liberação dos recursos

$N=$ número de dias até 0 vencimento do contrato

2.2.2. Decomposição do valor de negociação da $\mathrm{CPR}$ (VnCPR) para o valor líquido da $\mathrm{CPR}$ (VliqCPR)

O valor liquido da CPR (MliqCPR) foi definido como o valor que o produtor emitente recebe, efetivamente, por saca de soja vendida antecipadamente, descontado todos os custos operacionais envolvidos na negociação. Este valor deve ser, no mínimo, maior que seu custo de produção de forma a garantir uma margem para o produtor. 
Foi obtido a partir do valor de negociação da CPR (VnCPR) descontado os custos com aval ( $\mathrm{Ca}$ ) dado pelo Banco do Brasil ao emitente, e com as taxas para negociação através de leilão em bolsa de mercadorias (Ctx). Este seria o valor aproximado que o produtor ou emitente receberia quando da emissão da CPR em operações equivalentes as simuladas neste estudo.

O custo do aval é mensal e a taxa varia de acordo com a fase de desenvolvimento da cultura no momento da emissão do título (conforme descrito no capitulo 1; ver Tabela 3, p.17). Esta taxa mensal, segundo os técnicos do Banco do Brasil do Grupo de Trabalho BB/CPR, não é proporcional ao número de dias, ou seja, considera o mês cheio. Desta forma, numa operação com emissão da CPR em 10 de outubro de 1997 e vencimento para 15 de abril de 1998, serão considerados sete meses para efeito de cobrança da taxa mensal do aval. O cálculo da taxa no período baseia-se no conceito de juros simples.

A negociação da CPR através de leilão em bolsa de mercadorias representa um custo para o emitente ${ }^{13}$ de $0,60 \%$ (Ctx) por cédula emitida sobre o valor de negociação da CPR. Representa a soma das taxas de corretagem $(0,2 \%)$, da bolsa $(0,1 \%)$ e de leilão $(0,3 \%)$.

A equação 5 foi utilizada para a obtenção do valor liquido da CPR.

$$
V l i q C P R=V n C P R \bullet\{1-[(C a \bullet n)+C t x]\}
$$

Onde:

VliqCPR = valor liquido de negociação da CPR

$C a=$ taxa de aval

$C t x=$ taxa de negociação em bolsa

$n=$ número de meses em cada operação

13 Segundo os técnicos do Banco do Brasil, este seria um custo do comprador da CPR. No entanto, para este estudo considerou-se a premissa de NUEVO (1996) de que uma vez que o preço futuro reflete o preço de mercado, lodos os custos para a oblenção dos recursos recaem sobre o produtor. 


\subsubsection{Decomposição do valor de negociação (VnCMFG) para o valor líquido da CMFG (VliqCMFG)}

O valor líquido da CMFG (MiqCMFG) foi definido, também como no caso da CPR, como o valor que o produtor emitente recebe, efetivamente, por saca de soja vendida antecipadamente, descontado todos os custos operacionais envolvidos na negociação. Este valor deve ser, no mínimo, maior que seu custo de produção de forma a garantir uma margem para o produtor.

O VliqCMFG foi obtido a partir do valor de negociação, igual para o CMFG e a CPR, descontado: os custos com a fiança (Cf) ou com o Seguro Garantia de Obrigações Contratuais (Cs) dados, respectivamente, pela instituição financeira ou seguradora ao emitente; e as taxas para negociação através de leilão em bolsa de mercadorias (Ctx). Este seria o valor aproximado que 0 produtor ou emitente receberia quando da emissão da CMFG em operações equivalentes às simuladas neste estudo.

O custo da fiança é anual e varia conforme o cadastro e as garantias oferecidas pelo emitente. Esta taxa anual é proporcional ao número de dias até o vencimento do contrato. 0 cálculo da taxa no periodo baseia-se no conceito de juros compostos. Como alternativa a fiança bancária, pode ser utilizado o Seguro Garantia de Obrigações Contratuais (SGOC) que consiste numa taxa fixa, para periodos inferiores a um ano.

O CMFG deve ser registrado na clearing e negociado através de leilão em bolsa de mercadorias. Isso implica num custo de negociação que é dado pela Taxa de Registro de Negócios (TRN) - custo de registro do CM-G na Central de Registros S.A equivalente a $0,50 \%$ sobre o valor da operação; e pela Taxa de Negociação (TN) - equivalente a 0,5\% sobre a TRN, que compõe o fundo de liquidez. Somam $0,525 \%$ e são cobradas sobre o valor da operação para cada parte: vendedor e comprador, representando um custo total de $1,05 \%$. A TRN remunera a bolsa em $10 \%$, a clearing em $20 \%$, sendo que os $70 \%$ restantes são divididos, conforme acordo livremente estabelecido, entre o Membro Registrador e o corretor $^{14}$.

14 Para efeito das simulações, e considerado o fato de que a partir de 1996 o CM-G praticamente năo tem sido mais operacionalizado, para a 
As equações 6 e 7 foram utilizadas para a obtenção do valor líquido da CMFG.

VliqCMFG $=\operatorname{VnCMFG} \bullet\left\{2-\left[(1+C f)^{N / 360}+C t x\right]\right\}$

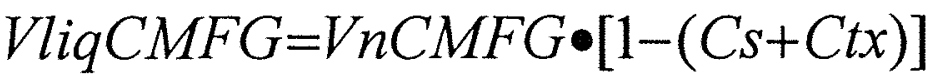

Onde:

VliqCMFG = valor líquido de negociação da CMFG

$C f=$ taxa de fiança

$C s=$ taxa de seguro

$C t x=$ taxa de negociação em bolsa

$N=$ número de dias até o vencimento do contrato

\subsubsection{Custo financeiro total}

A partir dos resultados obtidos anteriormente, PFOBPAR e o VliqCPR e VliqCMFG, e considerando-se a definição de VIEIRA SOBRINHO (1982) de que a taxa de desconto composto (por dentro ou racional), dada pela equação 8, é a própria taxa de juros compostos, foi possivel deduzir as equações 9 e 10 que permitiram obter as taxas de descontos efetivas envolvidas na negociação, respectivamente, da CPR e do CMFG.

$$
\frac{S}{P}=(1+d)^{n}
$$

operação iniciada em 1996, foram levados em consideraçăo os custos que incidiram na emissão do CM-G no perlodo 1993 a 1995, sendo portanto, mantidas as mesmas taxas. 
Onde:

$S=$ valor futuro, ou seja, o valor assumido pelo título na data de seu vencimento

$P=$ valor atual

$d=$ a taxa de desconto

$n=$ prazo

$\frac{P F O B P A R}{\text { VliqCPR }}=\left(1+d_{C P R}\right)^{N}$

$\frac{P F O B P A R}{\text { VliqCMFG }}=\left(1+d_{C M F G}\right)^{N}$

Onde:

PFOBPAR = preço futuro $\mathrm{FOB} / \mathrm{Paranaguá}$

Vliq $C P R=$ valor líquido da $\mathrm{CPR}$

VliqCMFG = valor liquido da CMFG

$d_{C P R}=$ a taxa de desconto envolvidas na negociação da CPR

$d_{C M F G}=$ a taxa de desconto envolvidas na negociação do CMFG

$N=$ periodo considerado

\subsubsection{Equivalente produto}

Tanto a CPR como o CMFG podem ser olhados sob o ângulo da obtenção de recursos com base em equivalente produto. Desta forma, foi calculado o número de sacas equivalentes ao volume de recursos que seriam postos a disposição do produtor através da emissão e venda desses titulos. O preço considerado para a saca de soja foi o da data de liberação dos recursos. 
Assim, no caso da CPR e do CMFG, o número de sacas equivalentes foi calculado a partir do valor líquido recebido pelo produtor por saca de soja no momento da negociação (VliqCPR e VliqCMFG) e do volume de recursos na data de cada liberação. A somatória do número de sacas, no caso de mais de uma liberação por safra, resulta no equivalente em sacas necessárias para cobrir o capital financiado em cada operação.

Já no caso do crédito obtido através do SNCR, foi utilizado o saldo liquidado do contrato, incluindo juros e correção, considerando que a venda do produto se deu na data de liquidação do contrato pelo preço equivalente ao preço futuro (PFOBPAR).

Os cálculos foram efetuados a partir das seguintes equações:

$$
\begin{aligned}
& E_{S N C R}=\frac{V}{P F O B P A R} \\
& E_{C P R}=\frac{V}{V l i q C P R} \\
& E_{C M F G}=\frac{V}{V l i q C M F G}
\end{aligned}
$$

Onde:

$E_{S N C R}=$ equivalente em sacas de acordo com a SNCR

$E_{C P R}=$ equivalente em sacas de acordo com a CPR

$E_{C M F G}=$ equivalente em sacas de acordo com o CMFG

$V=$ volume de recursos em cada uma das parcelas/contrato (CMFG e CPR) ou o saldo liquidado do contrato (SNCR)

PFOBPAR = preço futuro FOB/Paranaguá

Vliq $C P R=$ Valor liquido da $C P R$

VliqCMFG = Valor liquido da CMFG 


\section{CERTIFICADO DE MERCADORIA COM EMISSÃO GARANTIDA (CM-G)}

Nesta seção do trabalho, apresentamos um novo instrumento de comercialização e captação de recursos, o Certificado de Mercadoria com Emissão Garantida, que pode ser utilizado por produtores e compradores de produtos agricolas ${ }^{15}$, bem como a sua evolução.

A idéia original do CM-G data de 1988 e é de autoria do especialista em finanças Ademiro Vian, Assessor de Crédito Rural, Operações Bancárias e Contabilidade da Federação Brasileira das Associações de Bancos (FEBRABAN). A partir deste ano, contando com a colaboração dos coautores do CM-G, os senhores Heraldo Luiz Panhoca - corretor da Representações Kaufmann Ltda., Joaquim Antonio Almeida Prado - notório conhecedor das Bolsas de Mercadorias e do mercado físico de produtos agricolas e Paulo Domingues - reconhecido por sua larga experiência de atuação no mercado fisico através das cooperativas de produção, este instrumento foi sendo aperfeiçoado até chegar a sua forma final em 1992, quando foi registrado e, através de contrato e mediante autorização dos autores, passou a ser utilizado pelo mercado. As operações com esse certificado foram iniciadas em julho de 1993.

Ainda em 1992, os autores, através de contrato, cederam o direito de uso do CM-G, por periodo pré-determinado, exclusivamente para a Central de Registos $S / A^{16}$, empresa independente e com fins lucrativos que, como clearing do sistema, tinha como funçōes regular, registrar e garantir as operações do CM-G nas bolsas de cereais. Tornaram-se acionistas da Central de Registros S/A a Bolsa de Cereais de São Paulo (com aproximadamente $70 \%$ das ações), a Bolsa de Mercadorias do Paraná, a Minas Bolsa, a Bolsa de Mercadorias de Maringá, a Bolsa de Mercadorias de Uberlândia, a Bolsa de

15 Ver apêndices 9 a 13, que contêm cópia do CMDG e do CMFG com respectivos Boletos de Negociaçāo e cópia do Acordo de Clientes e Instrumento de Mandato.

16 A Central de Registros S/A localiza-se na Av. Senador Queiroz, 611 - 3 andar - São Paulo - SP. 
Mercadorias de Brasilia, a Bolsa de Hortifutigranjeiros de Recife e a Agrobolsa S/A.

Das bolsas relacionadas, as que mais operaram com o CM-G foram as Bolsas de São Paulo, Paraná e Minas Gerais. As fianças bancárias, necessárias para a negociação do $\mathrm{CM}-\mathrm{G}$, foram presta das pelos bancos: Banco do Estado do Espirito Santo SIA (BANESTES), Banco Fininvest S/A, Banco Pontual S/A, Banco Shahin Cury S/A e Banco do Estado do Paraná S/A (BANESTADO), sendo este último o mais ativo. Na sua maioria, estes bancos se tornaram Membros Registradores da Central Registros S/A.

O Membro Registrador é a instituição financeira conveniada com a cleaning, responsável pelo registro do $C M-G$, pela garantia da mercadoria negociada, cabendo a este registrar o armazenador, se for o caso, e cadastrá-lo na Central de Registros S/A.

A partir do seu lançamento, o CM-G foi sendo absorvido pelo mercado, apesar da dificuldade causada pela novidade que representava, além da resistência que enfrentou para a ampliação do quadro de acionistas da Central de Registros S/A, o que acabou por influenciar negativamente a adesão dos bancos como Membros Registradores, e portanto, na participação da emissão do certificado.

No entanto, esse fato não impediu que no ano de 1995 o volume de títulos negociados atingisse US $\$ 4,8$ bihões, distribuidos por 46 produtos. Os mais negociados em termos de valor foram a soja em grão, o milho e o boi gordo representando juntos $68 \%$ do total. No entanto, ocorreram também operações com insumos, produtos pré-beneficiados e industrializados (Tabela 4) que somados foram responsáveis por aproximadamente $22 \%$ do valor total negociado naquele ano. 
Tabela 4 - Volume total de operações com CM-G, por produto, 1995.

\begin{tabular}{|c|c|c|c|c|c|}
\hline Mercadoria & $\begin{array}{l}\text { Número de } \\
\text { Certificados }\end{array}$ & Volume & Un. & $\begin{array}{l}\text { Valor } \\
\text { (US\$) }\end{array}$ & $\begin{array}{c}\text { Valor } \\
(\%)\end{array}$ \\
\hline Soja Grão & 952 & 111.086 .867 & sc & $1.320 .622 .718,84$ & 27,46 \\
\hline Milho & 542 & 170.673 .785 & sc & $1.228 .123 .373,28$ & 25,53 \\
\hline Boi gordo & 325 & 24.603 .129 & @ & $725.003 .158,53$ & 15,07 \\
\hline Algodão em Pluma & 365 & 7.768 .493 & @ & $343.522 .870,03$ & 7,14 \\
\hline Madeira - Pinus & 57 & 5.551 .432 & m3 & $246.491 .307,98$ & 5,12 \\
\hline Fertilizante Químico & 151 & 576.106 & T & $190.195 .412,59$ & 3,95 \\
\hline Óleo de Soja & 12 & 168.750 & $\mathrm{~T}$ & $120.793 .032,60$ & 2,51 \\
\hline Óleo de Mamona & 26 & 85.598 & $\mathrm{~T}$ & $114.227 .593,89$ & 2,3 \\
\hline Café Robusta Conillon & 126 & 703.699 & sc & $113.551 .643,70$ & 2,36 \\
\hline Óleo de Soja Degomado & 15 & 80.400 & $\mathrm{~T}$ & $53.843 .399,42$ & 1,12 \\
\hline Laranja em Caixas & 10 & 17.590 .800 & $\mathrm{cx}$ & $50.064 .218,52$ & 1,04 \\
\hline Soja Semente & 47 & 1.119 .200 & sc & $49.259 .754,57$ & 1,02 \\
\hline Açúcar Cristal & 13 & 149.747 & $\mathrm{~T}$ & $39.338 .285,05$ & 0,82 \\
\hline Pimenta Preta & 74 & 248.469 & $T$ & $22.849 .800,18$ & 0,48 \\
\hline Soja Farelo & 17 & 90.534 & T & $20.407 .186,26$ & 0,42 \\
\hline Leite em Pó & 3 & 6.000 & $T$ & $20.039 .982,74$ & 0,42 \\
\hline Madeira Cortada & 24 & 188.100 & m3 & 19.903.485,07 & 0,41 \\
\hline Laranja Suco & 7 & 12.693 & $T$ & $19.740 .969,78$ & 0,41 \\
\hline Castanha de Caju & 3 & 25.500 & $\mathrm{~T}$ & $16.667 .633,84$ & 0,35 \\
\hline Café Arábica - Cons. Intemo & 45 & 104.150 & sc & $15.677 .658,22$ & 0,33 \\
\hline Álcool Hidratado (AEHC) & 23 & 35.118 & $\mathrm{~m} 3$ & $14.759 .009,78$ & 0,31 \\
\hline Calcário & 18 & 1.479 .977 & T & $13.368 .797,64$ & 0,28 \\
\hline Borracha & 14 & 3.939 & $\mathrm{~T}$ & $10.125 .968,48$ & 0,21 \\
\hline Açúcar Demerara & 8 & 26.476 & T & $6.693 .151,22$ & 0,14 \\
\hline Trigo Grão & 2 & 23.520 & $\mathrm{~T}$ & $4.497 .486,07$ & 0,09 \\
\hline Alcool Anidro (AEAC) & 6 & 17.892 & $\mathrm{~m} 3$ & $4.436 .366,87$ & 0,09 \\
\hline Frango Congelado & 5 & 3.109 & $\mathrm{~T}$ & $4.058 .071,39$ & 0,08 \\
\hline Algodão em Caroço & 10 & 522.230 & @ & $3.655 .189,48$ & 0,08 \\
\hline Arroz & 5 & 28.984 & sc & $3.625 .753,64$ & 0,08 \\
\hline Farinha de Mandioca & 30 & 235.000 & sc & $2.819 .251,10$ & 0,06 \\
\hline Feijão em Grão & 13 & 71.255 & sc & $1.996 .394,16$ & 0,04 \\
\hline Biscoito wafer empacotado & 3 & 504.000 & $\mathrm{Kg}$ & $1.898 .746,13$ & 0,04 \\
\hline Café em coco & 9 & 27.170 & sc & $1.793 .806,51$ & 0,04 \\
\hline Algodão Fio & 3 & 240.000 & $\mathrm{Kg}$ & $1.310 .106,83$ & 0,03 \\
\hline Arroz irrigado & 2 & 5.050 & sc & $1.213 .847,00$ & 0,03 \\
\hline Álcool Anidro Industrial & 3 & 2.157 & $\mathrm{~m} 3$ & $669.778,81$ & 0,01 \\
\hline Trigo Semente & 1 & 50.000 & sc & $659.248,00$ & 0,01 \\
\hline Sacaria de Rami & 2 & 460.000 & sc & $586.223,06$ & 0,01 \\
\hline Óleo de Amendoim & 1 & 465 & $T$ & $532.428,00$ & 0,01 \\
\hline Açúcar Refinado & 2 & 1.284 & $T$ & $453.159,00$ & 0,01 \\
\hline Vaca para Abate & 1 & 12.000 & $@$ & $164.471,95$ & 0,00 \\
\hline Fécula de Mandioca & 1 & 3.340 & sc & $66.159,07$ & 0,00 \\
\hline Madeira - Imbuia & 1 & 100 & $\mathrm{~m} 3$ & $62.630,48$ & 0,00 \\
\hline Fubá & 1 & 150.000 & $\mathrm{Kg}$ & $49.237,91$ & 0,00 \\
\hline Cana-de-Açúcar & 3 & 14.000 & $T$ & $41.504,08$ & 0,00 \\
\hline Laranja em Sacos & 3 & 8.100 & sc & $9.458,61$ & 0,00 \\
\hline Total & 2.984 & $\ldots$ & & $4.809 .869 .730,36$ & 100,00 \\
\hline
\end{tabular}

Fonte: Central de Registros S/A 
Em 1995 foram emitidos 2.984 certificados, sendo 2.905 CMFGs (para entrega futura) e apenas 79 CMDGs (para entrega imediata da mercadoria) representando, respectivamente, $99,53 \%$ e $0,47 \%$ do valor total negociado.

A comercialização de produtos dos vários segmentos da cadeia de agribusiness é uma das características do CM-G que demostra a versatilidade deste titulo que pode ser usado pela indústria, tanto a montante, na compra de insumos, matérias-primas e materiais de embalagem, como a jusante, na venda à vista ou para entrega futura de seus produtos industrializados ou semi-elaborados. $\mathrm{Na} \mathrm{Ta}$ bela 5 as operações efetuadas em 1995 estão classificadas por segmento da cadeia agroalimentar de acordo com RIBEIRO et alii (1995).

Tabela 5 - Volume total de operações com CM-G, por segmento de cadeia agroalimentar, 1995.

\begin{tabular}{llc}
\hline Mercadorias & Número de & Volume \\
& Certificados & (US\$)
\end{tabular}

Insumos

219

$254.069 .435,86$

5,28

fertilizante quimico, soja semente, calcário, trigo semente, sacaria de rami;

Produção dentro da porteira

$2.145 \quad 3.733 .820 .642,40 \quad 77,63$

soja grão, milho, boi gordo, madeira - pinus, café Robusta Conillon, laranja em caixas, pimenta preta, borracha, trigo grão, algodão em caroço, arroz, feijão em grão, café em coco, arroz irrigado, vaca para abate, cana-de-açúcar,

Produtos pré-beneficiados

$413 \quad 375.868 .162,09 \quad 7,81$

algodão em pluma, castanha de caju, café arábica - cons. interno;

Produtos industrializados

$207 \quad 446.111 .490,01 \quad 9,27$

óleo de soja, óleo de mamona, óleo de soja degomado, açúcar cristal, soja farelo, leite em pó, madeira cortada, laranja suco, álcool hidratado (AEHC), açúcar demerara, álcool anidro (AEAC), frango congelado, farinha de mandioca, biscoito wafer empacotado, algodão fio, álcool anidro industrial, óleo de amendoim, açúcar refinado, fécula de mandioca, madeira imbuia, fubá, laranja em sacos.

\begin{tabular}{lrrr}
\hline Total & 2.984 & $4.809 .869 .730,36$ & 100,00 \\
\hline
\end{tabular}

Fonte: Resultado da pesquisa (elaborada com base nos dados da tabela 4 e em RIBEIRO el alii, 1995). 
Tanto na venda à vista ou disponivel como na venda futura, a ưtilização do $\mathrm{CM}-\mathrm{G}$ permite 0 encadeamento das operações do produtor até a indústria através de formas variadas, como pode ser observado no item 3.2 .

O CM-G foi muito utilizado ${ }^{17}$ pelos Fundos de Commodities em operações triangulares, funcionando como a ponta compradora do certificado emitido pelo mercado fisico ou pela indústria. No entanto, para entrar na operação, o fundo exigia que o emitente ou o tomador se comprometesse com a recompra antes do vencimento do contrato. No item 3.2. são dados alguns exemplos de operações com o CM-G que tornarão mais claros os pontos colocados acima.

Os Fundos de Investimento em Commodities, regulamentados em julho de $1992{ }^{18}$, consistiram-se num importante estímulo ao processo de desenvolvimento do $\mathrm{CM}-\mathrm{G}$. $\mathrm{O}$ seu lançamento, levou o mercado a acentuar o debate sobre novos instrumentos de financiamento e comercialização agricolas que pudessem, inclusive, compor a carteira destes fundos, que tinha entre os seus objetivos a aplicação em papéis vinculados a produtos agropecuários como è o caso do Cerfificado de Mercadorias com Emissão Garantida . O seu sucesso de captação, logo nos primeiros meses de operação, veio reforçar a proposta de um novo título agricola e abrir espaço para a associação entre a produção rural e o capital financeiro.

Após um período de evolução crescente em termos de volume de recursos aplicados, que atingiu o máximo entre dezembro de 1994 e agosto de 1995, quando o patimônio líquido oscilou em torno de US $\$ 25$ bilhões, os Fundos de Commodities foram substituidos pelos Fundos de Investimentos Financeiros (FIF) em setèmbro de 1995, por ato do Conselho Monetário Nacional, com a intenção de desincentivar as aplicações com liquidez diária e incentivar as de longo prazo adaptando o sistema financeiro ao novo cenário de taxas de inflação bem inferiores às observadas nos últimos anos (NUEVO, 1996). No entanto, nada impede que esses novos fundos apliquem em papéis como o CM-G, em operações triangulares ou não, pois as carteiras podem ser forma-

Não há eslatísticas. Esta informação foi obtida nas entrevistas.

16 Circular BACEN n 2.205 de $2407 / 1992$ 
das com os mais variados tipos de papéis, e construidas para atender perfis variados de aplicadores, mais ou menos afeitos ao risco.

\subsection{Principais caracteristicas e mecanismos operacionais do $\mathrm{CM}-\mathrm{G}$}

O CM-G é um título mercantil de contrato de compra e venda, disponivel nas modalidades entrega fisica futura garantida - CMFG, e entrega fisica disponivel garantida - CMDG. Ele representa a garantia de entrega e a qualidade do produto oferecido e é exclusivamente negociado nas bolsas de mercadorias.

A grande inovação deste instrumento foi conferir ao produtor rural a condição de emissor do titulo de comercialização de seus produtos, que até o surgimento do $\mathrm{CM}-\mathrm{G}$ era atibuição exclusiva da indústria, através da nota promissória rural/duplicata rural, e dos bancos, via cédula de crédito rural e cédula de crédito industrial.

Outra caracteristica muito importante a ser destacada é a utilização do CM-G como instrumento de captação de recursos. Através da emissão de um CMFG o produtor pode custear a atividade que está sendo desenvolvida, obtendo em parcelas, no momento e volume adequados, os recursos necessários para conduzir a produção, comprometendo-se a entregar o produto vendido após a coTheita.

Neste contexto, vale salientar que os recursos captados via $C M-G$ estarão automaticamente indexados à unidade do produto, com base nas cotações das bolsas nacionais e internacionais na data em que for efetuada a negociação. Este é um ponto que vem ao encontro da demanda dos produtores na área de equivalência produto para efeito de obtenção de recursos, na medida em que permite a fixação de preços e antecipa para o produtor qual porcentagem da safra estaria comprometida com o financiamento da produção. 
No entanto, para que esse título possa ser aceito pelo mercado é necessário haver garantias de que o contrato seja cumprido. Para tanto, fazem parte do processo de negociação do CM-G os seguintes agentes:

1. o produtor e/ou detentor da mercadoria (vendedor/emitente);

2. o armazenador (fiel depositário);

3. a instituição financeira ou Membro Registrador (financiadora, custodiadora e fiadora);

4. a seguradora;

5. a clearing do sistema e seus membros registradores;

6. a bolsa e seus corretores oficiais; $e$,

7. o comprador.

A clearing, cujas funções são regular, registrar e garantir as operações nas bolsas de cereais, é o principal agente garantidor do sistema. O CM-G só passa a existir oficialmente, podendo então ser admitido para venda e revenda nos pregões das bolsas, e suas garantias a ter validade, quando devidamente registrado na clearing. Para tanto só serão aceitos os armazenadores, cadastrados pelos Membros Registradores, e entidades classificadoras, credenciadas pelas bolsas, ambos registrados junto a clearing.

A instituição financeira é outro dos agentes garantidores do sistema. Chamada de Membro Registrador é conveniada com a clearinge responsável pelo registro do CM-G e pela garantia da mercadoria negociada, cabendo a este registrar o armazenador e cadastrá-lo na Central de Registros SIA, quando for o caso, visto que 0 armazenamento pode ser feito também pelo emitente produtor por meios próprios (por exemplo, na própria fazenda com equipamentos de armazenagem adequados). $A$ emissão do CM-G é obrigatoriamente feita junto à agência bancária onde o vendedor mantém conta, a partir do aporte de garantias e abertura do limite de crédito para a obtenção da carta de fiança garantidora da operação. Como prestador da fiança e portanto, fiador do produtor ou detentor da mercadoria, cabe a instituição financeira a execução do emitente, caso não ocorra a liquidação do contrato como inicialmente estabelecido. O produtor pode optar, também, pelo Seguro Garantia de Obrigações Contratuais, que substituirá a fiança, depositando a apólice na agência bancária do Membro Registrador. 
A seguradora tem o papel de cobrir para o sistema como um todo os riscos de produção, no caso do CMFG, os riscos materiais das mercadorias, no caso do CMDG e os riscos de crédito. No entanto, estes seguros não são obrigatórios para a emissão do CM-G. No caso do não cumprimento do contrato pelo emitente, a clearing garantirá ao comprador a entrega da mercadoria que será adquirida no mercado e debitada ao Membro Registrador. Este acionará os seguros do produtor e na ausência destes executará suas garantias. Desta forma, é indicado que o produtor cubra seus riscos através de seguros.

Vale ainda salientar que eventuais diferenças quanto à qualidade do produto podem ser negociadas pelas partes, desde que feitas as devidas correçōes também nos preços. Essas alterações são registradas nos boletos de negociação, garantindo a realização do contrato.

A partir de 1996 o CM-G passou a admitir a cláusula a termo. Esta possibilita que vendedores e compradores na data de fechamento do negócio, estabeleçam no primeiro momento um preço referencial para a mercadoria transacionada fazendo constar no corpo do boleto uma cláusula a termo, onde com a escolha de indices de formação de preço futuro, pactuam um reajuste de preço, com divisão proporcional da diferença entre eles.

No caso da soja, podem ser escolhidos como referência a cotação na CBOT ou o indice da BM\&F ou FIPE ${ }^{19}$. Estabelecida uma paridade na data da contratação, fica negociado como será tratado uma variação de preços. Se esta variação for negativa, menor que o preço na data da contratação, nada será devido como complementação de preços entre as partes. Se a variação com relação ao valor de negociação for positiva, o comprador complementará o valor da mercadoria a favor do vendedor numa determinada proporção que também fica estabelecida no momento da negociação. Assim, pode ser estabelecido que $50 \%$ do valor da diferença será destinada ao vendedor. Esse percentual é de livre negociação entre as partes.

10 Indicador FIPE - Preço Nacional da Soja (PNS) definido como a média geométrica ponderada dos preços da soja no mercado disponivel, nas principais áreas de produçăo, calculados pela FIPE e sempre expresso em Reais (R\$) por unidade de $60 \mathrm{~kg}$ líquidos (SCHOUCHANA, s.d. "b"). 
A clearing do sistema, caso as partes não se ajustem na interpretação das condições estabelecidas, arbitrará o conteúdo da presente cláusula, e na ausência do prévio depósito do valor apurado a favor do vendedor, autorizará que o mesmo efetue a compensação do valor arbitrado com a diminuição da quantidade correspondente na entrega da mercadoria.

Esta nova cláusula adicionada ao contrato garante ao vendedor/produtor a participação no diferencial do preço final, podendo aumentar sua renda. Como conseqüência, este mecanismo pode ajudar a inibir o inadimplemento em situações em que o preço recebido antecipadamente for muito menor do que o valor da mercadoria na data da entrega (PANHOCA, 1996).

\subsection{Exemplos do fluxo rotativo do $\mathrm{CM}-\mathrm{G}$ na captação de recursos}

Para tornar mais clara a forma de utilização deste titulo pelos produtores e/ou detentores da mercadoria e compradores (agroindústrias, exportadores, etc.) é interessante apresentar alguns exemplos do fluxo rotativo do CM-G, dos mais simples aos mais elaborados em termos de engenharia financeira, envolvendo, nestes últimos, também o mercado futuro e de opções, como forma de administrar riscos associados a estas operações.

\subsubsection{Exemplo 1}

O produtor 1 vai ao banco 1 e por sugestão e oferecimento do banco 1 emite e coloca à venda um CMFG nas bolsas. Vendido o CMFG, o valor do titulo volta ao produtor 1 (descontado do percentual cobrado a titulo de fiança pelo banco 1 + as taxas de negociação em bolsa e registro na clearing), que utilizará esses recursos para o custeio da produção. 


\subsubsection{Exemplo 2}

O comprador 1 adquire nas bolsas matéria-prima (por exemplo, soja) pelo CMFG devido a garantia bancária de entrega fisica. Nestas condições, pode o comprador 1 oferecer à venda os seus produtos industrializados (por exemplo, farelo e óleo) através do CMFG, já que tem como base a real garantia da entrega fisica da matéria-prima adquirida, podendo desta forma planejar o seu processo produtivo. O produto industrializado do comprador 1 (farelo e óleo) pode ser matéria-prima do comprador 2 (indústria de ração), que em continuidade pode ser insumo do comprador 3 (produtor de frango $e$ suíno).

Este fluxo produtivo, de indústria para indústria, chega ao comércio e principalmente à exportação, onde a real garantia de entrega fisica é o elemento primordial nas relações comerciais. Calcado no aumento da credibilidade do vendedor, tem-se uma significativa redução do custo de captação dos recursos financeiros. Assim, um CM-G emitido de matéria-prima poderia ser comprado pela indústria e revendido para o Fundo de Commodities, até setembro de 1995, ou após essa data, para os Fundos de Investimentos Financeiros, com cláusula particular de recompra ${ }^{20}$. Desta forma, ocorre uma triangulação onde o funding do fundo é que carrega o papel, ou seja, o CM-G emitido pelo produtor e comprado pela indústria, é na verdade carregado pelo fundo através de um acerto de taxas entre este e 0 comprador do título.

Os próximos três exemplos foram desenvolvidos por PANHOCA (1996) e transcritos literalmente, com o intuito de registrar sua experiência sobre o tema.

20 A cláusula particular de recompra, apesar de ilegal, é utilizada particularmente entre os fundos e o comprador do título. Para os fundos, evita que venham a receber o produto fisico (o contrato normalmente finda antes do vencimento do título) e para o comprador, permile que o capital que seria empatado na compra do título permaneça disponivel até o seu vencimento, através de úm acerto de taxas entre o comprador e o fundo 


\subsubsection{Exemplo 3 - Venda $x$ Compra}

O emitente-vendedor (produtor de milho) em outubro de determinado ano vai ao Banco (Membro Registrador do Sistema) onde mantém sua conta bancária e tem limite de crédito por aporte de garantias.

Solicita a emissão de um CMFG prometendo entregar: 1000 sacas $(60.000 \mathrm{Kg})$ de milho amarelo brasileiro a granel safra ___.tipo especial, com máximo de $14 \%$ de umidade, máximo de $1 \%$ de impurezas, avariados até o máximo de $18 \%$ (estes com até $6 \%$ de germinados ou ardidos) peneira 3 , livre de sementes tratadas, com tolerância de $0,10 \%$, no periodo compreendido entre 01 a 15 de maio do ano seguinte, indicando ainda a cidade onde vai entregar o produto.

Para essa emissão ele ajusta com o Banco o custo da fiança ou apólice de seguro.

O Banco, após satisfeitas suas garantias, emite o CMFG e o custodia. Eletronicamente registra-o junto à clearing colocando-o a venda por intermédio de uma Corretora Oficial (à escolha do Banco ou do produtor).

O produtor determina o preço de venda, que ao ser apregoado pode receber dos possiveis compradores contra-ofertas de preço, local de entrega, data de entrega, etc.

Ajustadas as ofertas e contra-ofertas o negócio é fechado e o comprador, independente da data de entrega da mercadoria, paga a compra à vista $(D+1)$, pelo seu valor bruto (mercadoria+TRN).

Este pagamento é feito pelo comprador diretamente ao seu Banco Membro registrador, que por sua vez efetua o pagamento ao Banco Membro Registrador do vendedor (podendo usar a CETIP) e o vendedor em $D+2$ recebe de seu Banco Membro Registrador, o produto líquido da venda (que é igual ao valor da mercadoria menos a TRN menos a fiança ou apólice de seguro). 
Dependendo do produto, a Tabela de preços da TRN da clearing estipula uma taxa incidente sobre a operação. Assim sendo, o vendedor arcará com uma taxa de $0,3025 \%$ variando até 0,5025 sobre o valor do negócio. Igual procedimento é cobrado do comprador. Com esta taxa que é a usual do mercado físico agricola, estão remunerados todos os agentes que participaram da operação.

- Central de Registros SIA;

- Bolsa gestora do vendedor;

- Bolsa gestora do comprador;

- Corretora oficial do vendedor;

- Corretora oficial do comprador;

- Membro Registrador do vendedor; e,

- Membro Registrador do comprador.

Além desta TRN o vendedor somente pagará o custo da fiança ou apólice de seguro contra tada.

O emitente-vendedor para vir ao mercado através do sistema $C M-G$ não dispende numerário uma vez que nada the é cobrado antecipadamente, ou para fazer o seu registro no sistema.

Somente pagará as taxas cobradas e a fiança ou apólice de seguro pró-rata-tempore se o seu CM-G for efetivamente vendido. Na sua conta bancária será creditado o líquido da operação (preço da venda menos as taxas e fiança ou apólice de seguro).

Ao comprador só incidirá a TRN (Taxa de Registro de Negócio) sobre o valor da compra que deverá ser paga em $\mathrm{D}+1$ juntamente com o principal da mercadoria.

Nada impede que o vendedor e comprador se ajustem quanto ao pagamento dessas despesas contratuais (o vendedor poderá suportar as duas taxas, ou o comprador poderá suportar as duas taxas e a fiança ou apólice de seguro) este ajuste deverá constar do boleto de negociação, que poderá ainda receber quantas cláusulas adicionais forem ajustadas pelas partes. 


\subsubsection{Exemplo 4 - Vendedor $x$ Fundo de Investimentos Financeiros $x$ Comprador, ou Vendedor $\mathrm{x}$ Comprador $\mathrm{x}$ Nova Emissão de Venda (industrializado) $\mathrm{x}$ Comprador}

O emitente vendedor emite junto ao Banco o seu CMFG, prometendo entregar a mercadoria a futuro (procedimento igual ao primeiro exemplo).

A indústria de transformação, quer comprar tal CMFG para compor seu processo de fabrica ção no mês da entrega da mercadoria, entretanto não quer gravar naquele momento o seu capital de giro. A indústria compradora poderá adotar dois procedimentos distintos:

- Ajustar o preço com o vendedor e combinar com um Fundo de Investimentos Financeiros o indexador e a taxa de juros do periodo. O Fundo compra e paga o vendedor à vista, e a indústia, recompra do Fundo na data do vencimento do CM-G. A indústria fica com a mercadoria sem onerar seu caixa antecipadamente, 0 vendedor recebe o produto da venda no exato momento de sua necessidade, o Fundo cumpre sua finalidade, ou seja, atende a agricultura e produz rendimentos ao seu cotista.

- Ajusta o preço com o vendedor, efetua a compra com numerário de seu caixa, cauciona a fiança ou apólice de seguro recebida na compra da matéria-prima, emite CMFG referente a transformação da matéria-prima comprada, vem a mercado e vende 0 CMFG, refaz seu caixa, e pode reiniciar o ciclo de compras.

\subsubsection{Exemplo 5 - Escambo x Dinheiro à Vista}

O revendedor, distribuidor ou cooperativa, (qualquer produto) fará o trabalho de aglutinação dos emitentes-vendedores (produtores) junto à rede bancária credenciada na Central de Registros SIA. 
Com esse procedimento, cada produtor vai receber do banco uma carta de fiança ou apólice de seguros, nos limites das garantias aportadas, e com esta carta emitir CMFG de determinado produto de sua produção.

Assim, o produtor terá em sua mão a moeda equivalente para a aquisição de insumos, fertilizantes e sementes.

O revendedor, distribuidor ou cooperativa, efetuará a venda dos insumos, fertilizantes e sementes, e procederá a quitação desta venda com a compra do CMFG do produtor (é o tradicional escambo).

De posse do CMFG o revendedor, distribuidor ou cooperativa poderá:

1. Ficar com o CMFG em sua carteira para vender no momento que achar melhor preço, ou quando seu caixa assim exigir.

2. Pagar com o CMFG adquirido do produtor, a indústria vendedora dos insumos, fertilizantes e sementes.

3. Caucionar todos os CMFG recebidos, e com a soma das fanças ou apólices de seguro, emibir, agora em seu nome, como vendedora, um CMFG de prazo de entrega igual aos recebidos, e:

3.1. Deslocar a praça de entrega da mercadoria para o ponto de melhor formação de preço (porto ou região de indústrias).

3.2. Com esse procedimento, poderá ser alcançado melhor preço no produto final, além da agregação das despesas com serviços prestados.

3.3. Com a venda deste CMFG, será efetuado o pagamento às indústrias de insumos, fertilizantes e sementes, etc.

3.4. O produtor tem o dinheiro na hora certa, como resultado da venda de parte da sua produção (desatrelado da TR., já que é escambo), e o vendedor de insumos, fertilizantes e sementes (o revendedor, 0 distribuidor e a cooperativa que são os recebedores do escambo), com o CMFG, podem fazer dinheiro no ato pelo sistema de Bolsas, e as indústrias, vêem seu capital de giro voltar mais rápido, evitando inúmeras captações. 
Os próximos exemplos envolvem a utilização dos mercados futuros e de opções ${ }^{21}$ como recurso para administrar os riscos associados às operações com títulos agricolas lastreados em commodity, como o CM-G e a CPR, tanto para o emitente quanto para o credor ou tomador.

\subsubsection{Exemplo 6 - Estratégias para o credor com a utilização de mercados futuros}

O credor, ao comprar um título agricola, está alocando recursos para dispor do produto negociado no vencimento. Ou seja, está fazendo uma aplicação indexada por commodity, que tem embutida uma certa taxa de juros e, no caso de produtos de exportação, uma certa taxa de câmbio. Ao assumir essa posição, os riscos do credor são os de ter os seus recursos mal aplicados devido: a) à queda de preço do produto; b) ao aumento da taxa de juros; e, c) à queda da taxa de câmbio, em produtos de exportação (FRICK, 1995).

Para se proteger desses riscos o credor pode utilizar o mercado futuro. No caso do risco de queda de preços, como sua posição é comprada no mercado fisico (possuidor de mercadoria através do título), deve assumir posição vendida no mercado futuro ${ }^{22}$. Para ilustrar essa situação, utilizar-se-á o exemplo numérico abaixo, baseado em FRICK (1995), adaptado para o CM-G.

Considere-se que um investidor comprou um titulo agrícola por $R \$ 76.858,00$, em 16/11/94 (emissão), onde o emitente se obrigou a entregar 200 cabeças de gado bovino, de 18 arrobas cada uma, em 17/04/95 (vencimento), em curral e cidade pré-determinados.

Supõe-se que a taxa de câmbio na data da compra do título era de $R \$ 0,83 / \mathrm{N} \$ 1,00$ e que 0 credor esperava vender cada animal por US $\$ 500,00$ na data da entrega do produto. Desta forma, considerando-se uma taxa de juros de $3 \%$ ao mês, o crédito alcançou $15,92 \%$ no periodo (operação de

21 Maiores esclarecimentos sobre o mercado fuluro e de opçōes podem ser oblidos em: SCHOUCHANA, F. Mercados Fuluros e de Opçōes Agropecuários: teoria e prática. São Paulo, BM\&F, s.d. 36p., FORBES, L.F. Mercados futuros: uma introdução. São Paulo, BM\&F, 1994.

22 Não serăo comentadas as esiratégias para defesa no aumento da laxa de juros e alta da laxa de câmbio pois segundo FRICK (1995), se a caplação do recurso a ser aplicado pelo credor for pré-fixada, só o hedge no mercado da commodity delermina o spread entre taxas de captação e aplicação. 
100 dias úteis, sobre 245 do ano) ou 20,73\% ao ano, mais variação cambial, desconsiderando os demais custos da transação.

Assim, o risco de queda de preço poderia ser coberto vendendo 11 contratos futuros de boi gordo na BM\&F (equivalentes a 3.630 arrobas, ou aproximadamente 200 animais de 18 arrobas cada) a US $\$ 27,90$ por arroba para o vencimento maio de 1995 . Uma vez que o preço implícito na compra do título era de US $\$ 27,78$ por arroba (US $\$ 500,00 \div 18$ arrobas), teria-se uma cobertura adequada do risco. Se em maio a cotação caisse para US $\$ 26,80$, o ganho de US $\$ 1,10$ por arroba no mercado futuro (US $\$ 27,90$ - US $\$ 26,80$ ) compensaria o menor preço obtido com a venda dos animais no mercado fisico. Se o preço subisse, o mesmo valor de venda seria alcançado (US\$27,90 por arroba) pois não se poderia aproveitar as melhores condições do mercado à vista, devido às perdas ocorridas no mercado futuro.

\subsubsection{Exemplo 7 - Estratégias para o credor com a utilização do mercado de opções}

Outra alternativa do credor para proteger-se do risco de queda de preço do ativo é o mercado de opções. Comprando uma opção de venda ao preço de exercício esperado para o vencimento e lembrando que o credor é um lançador coberto, ou seja, está comprado no mercado físico (devido a compra do título), caso o preço do ativo cair, ele pode exercer a opção de venda, ou simplesmente, ganhar a diferença decorrente do aumento do prêmio, vendendo-a. Dessa forma, fixa-se um preço mínimo de venda para o produto, o que equivale a determinar um piso para o rendimento do título.

\subsubsection{Exemplo 8 - Estratégias para emitente com a utilização de mercados futuros}

Para o produtor rural, a captação de recursos através da emissão de títulos agrícolas, significa um empréstimo em equivalência produto. $O$ seu risco é o de ficar com um crédito caro, o que ocorre, por exemplo, quando o preço do produto negociado sobe acima daquele previsto para o futuro, que 
serviu de base para a operação. Para administrar esse risco ele deve assumir a posição comprada no mercado futuro do produto em questão. O exemplo numérico (FRICK, 1995) apresentado abaixo, adaptado para o CM-G, ilustra essa situação.

Um cafeicultor necessitando fazer melhorias no seu cafezal decidiu captar recursos através da emissão de um titulo agrícola. Dessa forma, em 16/02/95 emituu um titulo comprometendo-se a entregar 1.000 sacas de café tipo 6, bebida duro, no porto de Santos, em 15/08/95 (vencimento) recebendo à vista $R \$ 134.000,00$ ou US $\$ 158.579,88$, supondo uma taxa de câmbio na data da venda de $R \$ 0,845 / U S \$ 1,00$. Considerando uma taxa de juros de $3 \%$ ao mês, e que o preço esperado para setembro era de US $\$ 175,00$ por saca, a captação de recursos teria ocorrido a $10,35 \%$ no período (121 dias úteis, sobre 247 do ano) ou $22,28 \%$ ao ano, mais variação cambial, desconsiderando os demais custos da transação (comissões, armazenagem, fretes, etc.) e os custos financeiros dos ajustes diários.

Como a possibilidade de redução do custo do crédito só se verifica se ocorrer um movimento ascendente de preços, o cafeicultor sob essa expectativa deveria comprar dez contratos a US $\$ 175,00$ por saca. Se o mercado subisse para US $\$ 177,00$ por saca até o dia 15/08/95 (vencimento do titulo com entrega da mercadoria) o produtor deveria reverter a posição no mercado futuro vendendo dez contratos, que lhe garantiria uma receita adicional de US $\$ 2,00$ por saca a receber da bolsa. Com isso, teria reduzido o custo da captação de $22,28 \%$ ao ano para $19,44 \%$ ao ano, ambos sobre a variação cambial.

No entanto, se o mercado passar a apresentar queda de preços, o custo do crédito sobe na mesma proporção que cairia caso o movimento fosse de alta, isto é, pouco menos de $1,18 \%$ ao ano a cada oscilação de US\$1,00 por saca. Desta forma, é necessário encerrar a posição rapidamente, para evitar perdas maiores, visto que o produtor estaria sendo chamado a fazer ajustes diários. 


\subsubsection{Exemplo 9 - Estratégias para o emitente com a utilização do mercado de opções}

Da mesma forma que o credor, o emitente pode escolher o mercado de opções para protegerse do risco de alta nos preços. Ou seja, as operações com opções oferecem ao emitente a oportunidade de participar de uma possivel elevação nos preços. Assim, ele pode comprar uma opção de compra ao preço de exercicio esperado para o vencimento do título. Se o preço do ativo subir, ele vende a opção e ganha a diferença de preço (o preço da opção oscila mais do que o do ativo subjacente) ou exerce seu direito de compra, vendendo, a seguir, o produto à vista. Se o preço do ativo cair, ele não exerce a opção e perde o valor do prêmio, o que aumentaria o seu custo.

Nos quatro últimos exemplos, foram mostradas algumas possibilidade de utilização dos mercados futuros e de opções que permitem reduzir riscos associados a compra ou venda de titulos agrícolas lastreados em mercadoria.

Ao contrário do mercado futuro, no mercado de opções, uma vez pago o prêmio, não existe ajuste diário, o que se constitui numa vantagem, principalmente na atividade agricola que, em geral, só aufere receita num determinado periodo do ano. Comprando opções de compra, é possivel estabelecer um preço máximo de compra, mas não o preço mínimo. Comprando opções de venda fica assegurado um preço mínimo de venda, mas não um preço máximo. Fica estabelecido um seguro de preços cujo custo é o prêmio. Se o preço de exercicio no momento da liquidação não for atraente, a opção não é exercida, perde-se o prêmio mas provavelmente ganha-se no mercado fisico, se a opção for sobre o disponivel, ou no mercado futuro, se a opção for sobre futuro.

No entanto, como a utilização dos mercados futuro e de opções está sendo visto aqui como complementar ao de títulos agricolas, lastreados em produto, é preciso estar atento para as estratégias elaboradas. No caso do produtor, a decisão de vender antecipadamente o seu produto atavés da emissão de um título agricola se deve principalmente a necessidade de recursos para financiar a produção, bem como para fixar um preço de venda. Desta forma, quando ele decide comprar op̧̧ões de compra para poder participar de uma eventual alta de preços, a melhor solução para sair dessa posi- 
ção é vender a op̧̧ão e ganhar na diferença de preços.

As estratégias para o credor devem levar em consideração que o objetivo na compra do título é garantir a matéria prima para determinada data futura e fixar o preço de compra. Desta forma, quando ele compra uma opção de venda para se proteger da queda nos preços, caso isso venha a ocorrer, ele tanto pode vender a opção, ganhando na diferença de preços do prêmio, como exercer a opção, visto que com queda de preços provavelmente não haveria problemas com a oferta do produto no mercado.

As estratégias aqui apresentadas interessam a emitentes e compradores de titulos agricolas que desejem proteger-se do risco de oscilação de preços. No entanto, até o momento estão disponiveis na BM\&F apenas contratos futuros dos produtos café, boi gordo, soja, algodão, milho e cana-deaçúcar. No caso das opções, apenas para boi gordo e café. Este fato restringe ainda mais as possibilidades de estratégias. Outro fator relevante é que a cultura desses mercados é pouco difundida. Assim, o indicado, principalmente, para emitentes produtores, é fazer operações de hedge simples, seja no mercado de op̧̧̃es ou no mercado futuro, liquidando sua posição o mais rápido possivel quando a situação tornar-se adversa.

\subsection{Principais objetivos do CM-G}

O CM-G foi idealizado visando alguns objetivos. Dentre os mais importantes, destacase a transparência que confere às negociações à vista e a termo do mercado fisico, principalmente porque só é aceito para negociação em bolsa. Na medida em que qualidade, quantidade e preço passam a ser informações conhecidas por todos os participantes do mercado, a formação dos preços torna-se de mais fácil compreensão, aumentando o poder de barganha, principalmente, do produtor.

Desta forma, objetiva-se estimular os produtores rurais e cooperativas a comercializarem sua produção fisica diretamente com o mercado consumidor, exportador e industrial, pelo sistema de bol- 
sa, que tem como caracteristica ser livre, regularizado e transparente. Como conseqüência, através da utilização das bolsas de fisico, procura-se incentivar o fortalecimento da iniciativa privada, criando condições favoráveis à auto-regulação do mercado. Além disso, a concentração de oferta em mercados organizados aumenta a liquidez operacional dos titulos, favorecendo, também, sua tansparência.

Outro dos objetivos é ampliar as possibilidades de origem de recursos para a produção, através do CMFG, que permite aos produtores rurais venderem sua safra antes de iniciar o plantio, obtendo recursos para custear as despesas durante o periodo de cultivo (equivalente ao custeio). Essa possibilidade torna o produtor mais independente do sistema de crédito oficial.

O CM-G tem também o objetivo de permitir à indústria a programação de seu processo produtivo, utilizando-se do CMFG, através de operações coordenadas de compra de matéria-prima, a ser recebida fisicamente no futuro, e venda futura de sua produção industrializada, o que lhe permitirá uma eficiente utilização do capital de giro. Há, desta forma, a possibilidade de operar com menores estoques, dado que a entrega do produto é garantida nos termos do contrato, o que the permite ter uma planta menor e, portanto, reduzir os investimentos em capital fixo.

Para os setores agrícola e financeiro este titulo representa uma inovação importante, visto que até a sua criação não existia nada parecido no Brasil. O CM-Gé o primeiro título mercantil oferecido no mercado com caracteristicas próprias que dão confiabilidade às transações, tanto para o vendedor como para o comprador. Os vários agentes envolvidos, interligados pela clearing, ficam comprometidos com a efetiva liquidação da operação, o que reduz os riscos tão comuns às operações no mercado fisico, tornando a comercialização dos produtos agroindustriais mais ágil, segura e competitiva para todo 0 agribusiness.

\subsection{Principais vantagens do $\mathrm{CM}-\mathrm{G}$}

São várias as vantagens da ưtilização do CM-G. A mais importante delas é conferir transparência à comercialização dos produtos o que se deve à necessária operacionalização através de bol- 
sas de fisico. Neste mercado, as partes compradora e vendedora se encontram de forma organizada, propiciando condições de igualdade para todos os participantes. A transparência das negociações é alcançada na medida em que os preços são cotados em pregões públicos e, através da divulgação eletrônica das ofertas para todas as bolsas conveniadas com a clearing, abrangem um maior número de compradores e vendedores.

Desta forma, propicia aos produtores a tomada de decisões para a venda com base em dados tecnificados e confiáveis, o que permite aos mesmos negociarem seus produtos a preços realmente de mercado, tornando-os independentes dos Empréstimos do Governo Federal (EGF) e Aquisições do Governo Federal (AGF), cada vez mais restritos.

Outra importante vantagem do CM-G é possibilitar ao produtor obter recursos no mercado com base nas cotações do produto nas bolsas e não atrelados à correção por indexador financeiro. Ou seja, o produtor partindo do preço cotado nas bolsas - que normalmente reflete informações de safras, estoques, entre outras - estabelece o seu preço. Desse preço, como ele recebe à vista para entrega futura, é descontado uma taxa de juros. Esta taxa é, portanto, conhecida antecipadamente e não sofre oscilações.

Com a utilização do CM-G, fica eliminada a necessidade do complicado contrato de compra de safra futura, que a indústria de transformação de produtos agropecuários firma com o produtor. Por um lado torna o produtor um parceiro menos vulnerável nas negociações, visto que os preços passam a ser mais transparentes. Por outro, permite à indústria não correr riscos em uma área que não é sua especialidade, o financiamento (STADUTO e MARQUES, 1995).

Outra das vantagens é introduzir novo relacionamento comercial entre o setor rural e o governo, a indústria e o comércio, bem como com o sistema financeiro e securtário, tornando a comercialização mais segura e confiável. Este fato, que decorre da atuação de todos os participantes do sistema negocial do $\mathrm{CM}-\mathrm{G}$, dando credibilidade ao certificado, estimula e contribui para o desenvolvimento do mercado secundário de títulos rurais. Ou seja, os títulos representativos de mercadorias passam a ser atraentes para compor a carteira de fundos diversos, de investimentos e de commodities, para in- 
vestidores no país e no exterior, para as bolsas e os mercados futuros. Em decorrência, a liquidez desse mercado torna-se maior, abrindo espaço para o aumento de recursos aplicados no setor, resultando num menor custo para o tomador.

Além disso, o CM-G melhora a eficiência e o desenvolvimento do mercado fisico e dos mecanismos de formação de preços para os diversos produtos. Desta forma, indiretamente, favorece a consolidação dos mercados futuros agricolas que passam a ser buscados pelos produtores para proteção contra variações de preços (STADUTO e MARQUES, 1995).

Destaca-se também a possibilidade de redução dos gastos do governo com financiamento de custeio e comercialização, armazenagem, transporte, manutenção de estoques e seguro das mercadorias, visto que estes custos estão inclusos no valor de negociação do certificado. Além disso, permite ao governo estimular, de forma planejada, o plantio de determinadas culturas, e em determinadas regiões, adquirindo a saffa antes de ser plantada, via aquisição do $\mathrm{CM}-\mathrm{G}$. É um instrumento que além de dar a condição de formar ou desovar estoques reguladores, principalmente nos produtos considerados prioritários, também prioriza a regionalização via aquisição e venda dos certificados nas bolsas. Desta forma, o governo estará contibuindo para a maior estabilidade dos mercados, dado a transparência com que estará atuando.

\subsection{Situação atual do Sistema de Negociação do CM-G.}

O volume de negócios com o Certificado de Mercadoria com Emissão Garantida, CM-G, atingiu US $\$ 4,8$ bilhões no ano de 1995. No entanto, estão paralisados desde o inicio de 1996, em parte devido ao processo de esvaziamento da Central de Registros S/A - clearing do sistema que detém o direito de uso e é a única autorizada a operar com o Certificado - após desentendimentos com sua maior acionista, a Bolsa de Cereais de São Paulo. Além disso, outros fatores também contribuiram para a não consolidação do $\mathrm{CM}-\mathrm{G}$, em particular, e do mercado de títulos agrícolas em geral. 
Segundo Ademiro Vian ${ }^{23}$, um dos autores do CM-G, são cinco os fatores básicos para o não crescimento e consolidação desse mercado de titulos agricolas ${ }^{24}$.

1. A não definição por parte do Governo Federal de uma politica agricola clara, principalmente no que tange à politica de comercialização e financiamento, bem como a falta de apoio ao desenvolvimento de novas técnicas de comercialização, propostas pelo setor privado. 0 governo, apesar de ter caminhado em direção a uma polítca agricola mais seletiva em termos de crédito rural, através de programas especiais como o Programa de Fortalecimento da Agricultura Familiar (PRONAF), o Programa de Geração de Emprego e Renda (PROGER) e o Programa Especial de Crédito para a Reforma Agrária (PROCERA), e menos intervencionista com a introdução dos Contratos de Opção, o risco de intervenção ainda representa um risco institucional para o mercado

2. Falta de interesse e apoio efetivo do mercado industrial constituido de monopólios e oligopólios que se beneficiam da desorganização do mercado e, portanto, não apoiam efetivamente projetos e idéias que contribuam para a organização do mesmo. Num mercado organizado, é possivel um planejamento de custos estreitamente ligado à realidade, propiciado pela formação de preços atra vés da difusão e transparência das informações. $O$ setor das agroindústrias tem uma atitude de aproximação e apoio a projetos como o do CM-G mas, contraditoriamente, não colocam o seu peso para contribuir com a consolidação desse mercado.

3. O mesmo é observado por parte das entidades de classes rurais que não demonstram real empenho para consolidar a organização do mercado. Não há uma abitude de apoio claro, por exemplo, com atuação junto aos produtores, apesar de publicamente defenderem métodos de comercialização mais modernos e seguros como o CM-G.

4. Considerar o sistema financeiro, especialmente bancos, como acionista indispensável da clearing. É um equivoco exigir-se essa posição dos bancos pois o sistema já opera com as clearings finan-

23 VIAN, Ademiro (Federaçăo Brasileira das Associaçjes de Bancos, FEBRABAN, Assessor de Crédto Rural, Operaçōes Bancárias e Contabilidade) Comunicaçāo pessoal, 1996.

24 Esse mercado de titulos agrioolas inclui, entre outros, a CPR, operada pelo Banco do Brasil. 
ceiras. A participação dessas instituições deve ser como operadores e membros registradores e financiadores.

5. Falta de apoio governamental para o desenvolvimento das Bolsas de Cereais do pais e para o aprimoramento dos corretores. Seria necessário despertar o interesse desses agentes através de programas de reciclagem.

No esforço para não deixar morrer o instrumento de comercialização e alavancagem de recursos via $C M-G$, um grupo de técnicos da Central de Registros S/A - apoiados pela Associação Brasileira de Agribusines (ABAG) e a Associação das Indústrias da Alimentação (ABIA) - movimentou-se para criar uma nova clearing no mercado fisico, a Companhia Nacional de Registros, CNR, que tem como acionistas um grande número de agroindústias e entidades de classes rurais, como: Arisco Produtos Alimenticios Ltda., Ceval Alimentos S/A, Fertiza Cia Nacional de Fertilizantes, Associação Brasileira das Indústrias de Café (ABIC), Nesté Industrial e Comercial Ltda., Quaker Brasil Ltda., Sociedade Rural Brasileira (SRB), Banco Industrial do Brasil, Bolsa de Mercadorias de Brasilia, entre outros.

Em abril de 1996 a CNR iniciou operações com contratos CNR, que tem, na essência, as mesmas características do $\mathrm{CM}-\mathrm{G}$, que não pode ser utilizado sem que ocorra a rescisão do contrato de direito de uso do CM-G estabelecido com a Central. No entanto, o volume negociado ainda é muito pequeno.

Ademiro Vian, acrescenta que não acredita no desenvolvimento desse mercado a curto prazo, o que não significa a descrença nos beneficios que esses instrumentos podem trazer e na consolidação desse processo nos próximos anos. 


\section{ESTRUTURA QUE DÁ SUPORTE AO CM-G}

A viabilidade do mercado de titulos para a comercialização de produtos agropecuários depende do bom funcionamento do mercado fisico de produtos. Segundo SOBOLL (s.n.t), a organização desse mercado depende de alguns pressupostos básicos, entre os quais destacam-se os seguintes: a) condições adequadas de armazenamento de produtos agricolas; b) padronização e qualidade dos produtos, mediante sistema de classificação e arbitragem aceito pelo mercado; c) uniformidade nos contratos e equanimidade nas condições contratuais entre vendedores e compradores; d) negociação pública desses contratos, estimulando a presença de investidores e especuladores no mercado; e) preços transparentes e difundidos para todo o mercado; e, f) confiabilidade e garantia no cumprimento dos contratos, através de sistema de compensação, administração de garantias e liquidação, universalmente aceito.

No entanto, a concretização desses pressupostos só ocorre com a atuação das bolsas de fisico, das câmaras de compensação, e dos sistemas de classificação, armazenagem e seguro. A interação destes agentes constitue a estrutura básica que dá suporte ao processo de comercialização agropecuária através de titulos, dentre eles, o CM-G.

A proposta deste capitulo é descrever esta estrutura, considerando os principais agentes envolvidos na operacionalização do CM-G salientando a importância e função de cada um deles nesse processo. 


\subsection{Bolsa de Mercadorias ${ }^{25}$}

Os fundamentos das funções das bolsas de mercadorias tem séculos de existência. $\mathrm{Na}$ Grécia e Roma antigas já existia uma certa formalização dos mercados que se constituia em lugar e tempo determinados para negociar (mercado localizado), sistemas comuns de troca e de moeda, além da prática do contrato para entrega futura. Apesar da queda dessas civilizações, os principios básicos de um mercado central sobreviveram à Idade Média, mesmo com a destruição do fluxo de comercialização ampla, substituido pelas feiras medievais de âmbito regional.

Com o desenvolvimento da cidade moderna, a melhoria dos transportes e das comunicações, essas feiras perderam importância dando lugar às praças comerciais especializadas, que começaram a se desenvolver em várias partes do mundo. Tais mercados na Europa eram designados de bourse, boerse, beurse, onde se falava espanhol, de bolsa. No inicio, esses mercados funcionavam em praças públicas, ao ar livre. Posteriormente, passaram a ser organizados em casas de chá ou hospedarias, até que passaram a ter instalações próprias e permanentes.

As bolsas de mercadorias seguiram algumas das práticas das feiras medievais, como a adoção de regras de auto-regulação e de métodos de arbitragem e de aplicação de normas, sendo que a principal contribuição da feira medieval ao comércio moderno foi a formalização de práticas de negociação, que foram codificadas e passaram a ser conhecidas na Inglaterra medieval como Lei Mercantil (Law Merchant). Esse código estabelecia os padrões de conduta que constituiram a base das práticas comuns no uso de contratos, notas de venda e de embarque, recibos de armazenagem, cartas de crédito, transferência de escrituras e outras letras de câmbio. Foi no século XVIII que, através de regulamentação própria, as bolsas tiveram sua consolidação.

O desenvolvimento das bolsas e dos centros de troca atingiram, também, o Japão e os Estados Unidos, além da Europa. Em 1730 já funcionava em Osaka a maior bolsa de mercadorias do Ja-

2s Este item foi escrito com base nos seguintes trabalhos: CHICAGO BOARD OF TRADE (1985), SANDRONI (1985), CENTRAL DE REGISTROS S/A (1995), ALMEIDA PRADO, (s/d). HIERONYMUS (1971), RIBEIRO el ali (1995). 
pão, a bolsa de arroz. A partir de 1752, Nova lorque também passou a contar com uma bolsa onde era negociada a produção local. A Chicago Board of Trade (CBOT) foi organizada em 1848 operando inicialmente com o mercado disponivel, tendo o mercado a termo entrado em operação em 1865 (HIERONYMUS, 1971).

\subsubsection{Bolsas de mercadorias no Brasil}

No Brasil, a primeira Bolsa de Mercadorias foi a do Rio de Janeiro, inaugurada em 1912, e na qual se faziam negócios de café, àçúcar e algodão. Desativada no ano seguinte, foi substituida, em 1920, pela Bolsa de Café, que servia também para transações de açúcar e algodão. Em 1913, o Governo do estado de São Paulo criou a Bolsa de Café de Santos, e, em 1917, abriu-se a Bolsa de Mercadorias de São Paulo (BMSP) (SANDRONI, 1985, p.35).

A BMSP, inaugurada em 03 de abril de 1918, foi a bolsa brasileira que deteve a maior experiência com mercados a termo de mercadorias, tendo admitido negociaçōes nesse mercado, de algodão em caroço e em pluma, arroz em casca e beneficiado, açúcar, feijão, mamona e milho a partir de agosto de 1919. O mercado a termo de algodão foi o que permaneceu até a década de 70, como decorrência de uma crescente especialização nas atividades dessa bolsa.

A fase mais recente da BMSP iniciou-se a partir de abril de 1978 quando foram reativadas as negociações de futuros, iniciadas com operações de café e soja, e posteriormente complementadas com operações de milho, boi gordo, farelo de soja e ouro (1.000g e $250 \mathrm{~g}$ ). Nessa ocasião, foram iniciadas as atividades do Sistema Nacional de Negócios a Termo S.A. que, mediante convênio com a BMSP, exerceu o papel de câmara de compensação e liquidação dos negócios (TSUNECHIRO, 1986).

Em julho de 1985 surgiu a Bolsa Mercantil \& de Futuros (BM\&F) e seus pregões começam a funcionar em janeiro de 1986. No entanto, quando da sua formação, a BM\&F adquiriu o Sistema $\mathrm{Na}$ 
cional de Negócios a Termo S.A. Por esse motivo, a BMSP reativou a Caixa Nacional de Liquidação de Negócios a Termo e Disponivel S.A. como seu novo clearing continuando seus negócios a futuro. Dos negócios agrícolas, os mais importantes foram o boi e o café, ficando em segundo plano a soja, 0 algodão e o milho.

Em maio de 1991 a BM\&F incorporou a BMSP, incluindo a Caixa Nacional de Liquidação de Negócios a Termo e Disponivel S.A. Dessa união surgiu a Bolsa de Mercadorias e Futuros, que manteve a mesma sigla BM\&F, cujo objetivo é desenvolver mercados futuros de ativos financeiros, agropecuários, e outros.

Tanto a compra do Sistema Nacional de Negócios a Termo S.A., quanto a incorporação da BMSP, incluindo a Caixa Nacional de Liquidação de Negócios a Termo e Disponivel S.A., levaram ao fechamento dos dois sistemas de clearing fisico/financeiro instalados naquela bolsa, gerando exclusividade operacional dos mercados de futuros junto a BM\&F (SOBOLL, s.n.t).

A Bolsa de Cereais de São Paulo, foi criada por volta de 1917 pelos comerciantes de cereais de São Paulo, com a denominação inicial de "Centro do Comércio do Pari". Segundo TSUNECHIRO (1986) os antecedentes que resultaram na criação da BMSP foram semelhantes aos que originaram a atual Bolsa de Cereais de São Paulo e mesmo das primeiras bolsas americanas em meados do século XIX. O crescimento e a diversificação da produção agrícola e industrial no início deste século fizeram crescer o volume de negócios com mercadorias de origem agrícola na praça de São Paulo, levando os produtores, compradores, exportadores e consumidores a perceberem a necessidade de criação de um mecanismo capaz de organizar o mercado em rápido crescimento e incorporar a ga rantia dos direitos e obrigações dos envolvidos, o que se daria através das negociações em bolsa, sejam de contratos futuros ou disponivel. 


\subsubsection{Definição, objetivos e funções das bolsas}

Os primeiros mercados de commodities, além de fornecerem locais para as negociações, serviam para atrair interesses comerciais variados, corretores, proprietários de navios, financistas e especuladores com capital de risco, além dos fornecedores de produtos primários e usuários das mercadorias.

As bolsas de mercadorias podem ser definidas como "mercado centralizado para transações com mercadorias, sobretudo os produtos primários de maior importância no comércio internacional e no comércio interno, como café, açúcar, algodão, cereais, etc. (as chamadas commodities). Realizando negócios tanto com estoques existentes quanto com estoques futuros, as bolsas de mercadorias exercem papel estabilizador no mercado, minimizando as variações de preço provocadas pelas flutuações da procura e reduzindo os riscos dos comerciantes" (SANDRONI, 1985, p.35). Segundo ALMEIDA PRADO (s.d.) é "o lugar onde se concentram propostas de oferta e procura, com o fim de viabilizar a realização das transações comerciais, estabelecendo por conseqüência o preço" e, segundo Yo ${ }^{26}$ citado por STADUTO (1995), é uma instituição, cujo objetivo não é a obtenção de lucro, porém, de fornecer as facilidades, por meio das quais os seus participantes poderão conduzir as negociações.

Os objetivos e funções das bolsas são:

1. estabelecer conduta comercial para seus participantes;

2. prover um local de negociação organizado, compativel com o desenvolvimento dos trabalhos e com o crescimento dos mercados, possibilitando a concentração de propostas de oferta e procura em um só local e em horário certo, constituindo-se no principal serviço prestado pela bolsa, pois a dispersão de propostas gera ignorância da posição real de mercado e o desencontro dos interessados.

3. prover regras e padrões uniformes para a condução dos negócios ${ }^{27}$;

26 YO, G. I. Operacoes a termo de mercadorias: commodties. 3 ed. São Paul, Gedmex, 1984. 2080.

27 Há de se ler a normatização para regétos, obrigando as partes contratantes e intervenientes. A estruturaçăo da botsa depende de um estatuto de sua composição e de regulamentação para os diversos mercados e atos de comércio praticados en seu recinto e por seus componentes. 
4. estabelecer uniformidade de tamanho dos contratos, de época e local de entrega, e termo de pagamento;

5. coletar e disseminar preços e informações de mercado aos membros e ao público;

6. proporcionar mecanismos de ajuste e de disputa entre seus participantes. Através de leilão aberto, público e de viva voz, permitir a fixação dos preços de commodities operados em pregão, de acordo com a vontade exclusiva do mercado, em regime de livre concorrência e segundo as leis de oferta e procura; $\mathrm{e}$,

7. proporcionar mecanismos para garantir o cumprimento do contrato e o pagamento das obrigações financeiras negociadas entre os membros.

\subsubsection{Vantagens da operação em bolsas e desvantagens do "mercado de balcão"}

As bolsas oferecem uma série de vantagens ${ }^{28}$ aos seus usuários e aos mercados que dela se utilizam, pois balizam o mercado dos produtos, pela formação e divulgação dos preços correntes e futuros, facilitando a tomada de decisões de todos os segmentos que compõem o agribusiness, bem como, permitem minimizar os riscos de variações de preços (de queda, no caso dos vendedores e, de alta, no caso dos compradores) transferindo-os dos produtores e intermediários do agribusiness para os investidores e especuladores, que podem aportar significativo volume de recursos para o mercado.

Além disso, constituem-se em lugar ideal para negociação dos estoques governamentais de emergência ou outros ${ }^{29}$, pois, por excelência são um centro de concentração de interessados, o que assegura a transparência na apuração do preço desses estoques; possibilitam às próprias entidades governamentais a substituição de estoques reguladores físicos pelos chamados "estoques papel" (compras no disponivel ou a futuro através de titulos representativos de mercadorias) restringindo os gastos públicos com armazenagem, transporte, manutenção de estoques e seguro, que seriam trans-

26 BOLSA DE MERCADORIAS DE SÄO PAULO A Comercializacaão na nova lei agricolă, São Paulo, s.d. $6 \mathrm{p}$

29 Os leilöes efetuados pela Companhia Nacional de Abastecimento (CONAB), ocorrem sempre nas bolsas de mercadorias. 
feridos para a iniciativa privada ${ }^{30}$; são entidades prestadoras de serviços, não diretamente envolvidas na comercialização ou no interesse das partes; e as pendências são entregues ao Juizo Arbitral da Bolsa, que tem condições de resolve-las de forma rápida e econômica.

Um mercado paralelo de comercialização de produtos agropecuários são as negociações do tipo "mercado de balcão", que apesar de amplamente utilizadas, principalmente em mercados não organizados como o de produtos agricolas no Brasil, apresentam uma série de desvantagens.

Em primeiro lugar, como a negociação è privada e reservada, permite 0 uso de informação privilegiada o que leva o comprador e o vendedor a negociarem sem concorrência. Nesta situação, o poder de barganha do mais forte rompe o equilibrio da relação comercial entre as partes, o que é acentuado pela ausência de regras e normas preestabelecidas. Além disso, o preço estabelecido baseia-se em informações nem sempre isentas, facilitando negócios que resultam em prejuizo de uma das partes, normalmente o vendedor.

Outas desvantagens do mercado de balcão residem no fato do sistema de armazenamento utilizado não possuir a garantia da estrutura institucional da bolsa, implicando, normalmente, em taxas de senviço mais caras, e de que, em caso de pendências, estas são entregues à justiça comum implicando em resultados demorados e custos elevados.

\subsubsection{O CM-G e a utilização das bolsas}

O desenvolvimento do mercado agropecuário brasileiro foi marcado pela intervenção governamental no estabelecimento da políica de crédito rural, como visto anteriormente, e da politica de ga rantia de preços mínimos (PGPM). Esta estabelecia, e ainda estabelece, os preços minimos garantidos pelo governo, sendo responsável pela sustentação dos preços agrícolas no mercado através dos

30 As medidas de politica anunciadas no Plano de Safra 1996/97 demonstratam que governo tem apontado na direçăo da privatizaçăo do financiamento agrícola, principalmente da comercializaçăo. Tais medidas săo: a restriçăo a utilização da Aquisiçăo do Governo Federal (AGF), a programas especiais; extinção do Empréstimo do Governo Federal com Opção de Venda (EGF.COV); e, o lançamento dos Contratos de Op- 
mecanismos de aquisição e financiamento dos estoques privados, ou seja, a Aquisição do Governo Federal (AGF) e o Empréstimo do Governo Federal (EGF). No entanto, a partir de 1986, mas principalmente entre 1987 e 1992, foram verificados cortes nos recursos públicos destinados a sustentação da PGPM tornando-a praticamente inoperante (LOPES, 1994a).

Como resultado desta politica intervencionista, o mercado de produtos agropecuários não se desenvolveu, tanto por conseqüência das medidas de politica ${ }^{31}$ como também, de certa forma, por tornar-se acomodado a essa situação. Assim, o desenvolvimento do mercado de futuro e de físico não se consolidou, apesar das várias tentativas, bem como suas respectivas bolsas.

Especificamente no caso das bolsas de fisico, que foram criadas em todo pais alimentadas principalmente pelos leilões de estoques do governo, com o enfraquecimento da PGPM, perderam sustentação. Algumas, como a Bolsa de Cereais de São Paulo, mais estruturadas partiram em busca de novas opções de comercialização como o warrant - ouro do Banco do Brasil, leilões de cereais pertencentes a iniciativa privada, leilões de café, o CM-G, etc. (SOBOLL, s.n.t).

Desta forma, o projeto do CM-G contou com o apoio da Bolsa de Cereais de São Paulo, que, como instituição, de acordo com as funções básicas já descritas anteriormente, atenderiam aos objetjvos do certificado que, segundo SOBOLL (s.n.t), "foi desenvolvido visando dar ao mercado e aos produtores rurais um instrumento confiável e transparente para a comercialização de produtos agropecuários e agroindustriais". No entanto, o que se conclui, é que o papel institucional da bolsa, por si só, não foi suficiente para ampliar as negociações com o certificado ${ }^{32}$.

Segundo o que foi possivel apurar através desta pesquisa, faltou a bolsa e seus corretores

\footnotetext{
ção.

31 "Afxaçăo de compulsoriedade ("exigbilidade do crédito rural) da aplicaçäo de recursos financeiros dos bancos en crédito rural, a definiçăo de subsídos via crédto, o estabelecimento de taxas de juros de acordo com os interesses casuisticos da politica agricola, o estabelecimento do volume de aquisiçöes de estoques, suas remoçöes e sua utilizaçäo para interferir no mercado de acordo com os determinantes governamentais, a política de seguro de crédto e orcamento rural, a politica de armazenamento, os confiscos de produtos de exportaçäo, a fixaçäo de tarifas, a importaçăo por parte do governo - essas, e inúmeras outras medidas decorrentes da politica governamental, engessaram a criatividade caracleristica dos mercados agropecuários, gerando obstáculos ao sadio desenvolvimento da comercialização de commodities agropecúárias, inclusive do respectivo mercado de fuluros" (SOBOLi, s.n.t.).

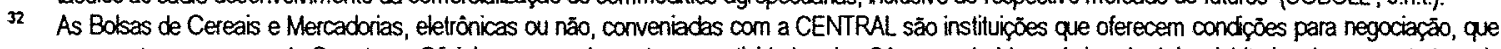
representam um corpo de Corretores Ofciais, que regulamentam as atividades das Câmaras de Mercadorias do Juizo Arbitral e de uma estrutura de Classificação e Arbitragem de produlos" (CENTRAL DE REGISTROS S/A, 1995).
} 
um melhor conhecimento das possibilidades de negociação com o CM-G e a habilidade, tanto para trazer compradores e vendedores interessados em utilizar o certificado para comercialização dos seus produtos, como para desenvolver operações. Apenas alguns corretores foram capazes de montar estratégias, envolvendo principalmente os Fundos de Commodities ${ }^{33}$, e operar com o CM-G. Além disso, pode-se considerar também como um entrave ao desenvolvimento do certificado, a falta de interesse do mercado em comercializar no disponivel ou a futuro através da bolsa, refletido no baixo volume operacionalizado dos vários produtos agricolas, quando comparado ao volume produzido. Estes, entre outros fatores limitaram a ascensão do CM-G.

\subsection{Câmara de Compensação}

As câmaras de compensação ou cleanings são associações muito conhecidas e utilizadas pelo sistema bancário e de bolsas, seja de valores ou de commodities. No entanto, apesar da função de compensação que é comum a elas, facilitando a transferência de recursos entre as partes contratantes e seus agentes, diferem com relação ao papel e à atibuição que desempenham.

As mais conhecidas são as câmaras de compensação bancárias, que fazem a compensação interbancánia de cheques. Elas organizam a transferência de fundos entre sacados e sacadores, mas não são parte legal na transação, não atuam como garantidoras da liquidação, nem operam como instituto auto-regulador do mercado báncário.

As câmaras de compensação relacionadas às bolsas, têm como caracteristica serem câmaras de registro, liquidação e compensação que operam a função financeira, concluindo as negociações de uma bolsa de negócios ou mercado de titulos.

Segundo Franklin Edwards ${ }^{34}$ citado por FORBES (1994), para o mercado futuro, a clearingé

33 Exemplos de operações envolvendo o CM-G e Fundos de Commodities foram apresentados no capitulo três.

34 Franklin R. Edwards. "The Clearing Association in Futures Market" in: The Joumal of Futures Market. New York, NY, 1983. v.3, n4, p.369. 
a "entidade chave que transforma o que não passaria de simples contratos a termo em contratos a futuro de alta liquidez. Através de suas normas e regulamentos e de suas atividades de supervisão de crédito, a câmara de compensação, igualmente, desempenha papel de enorme importância para a manutenção da integridade financeira da indústria de futuros como um todo. E, em conjunto com as bolsas organizadas, constitui a base institucional dos mercados de futuros".

Ainda segundo o mesmo autor, as câmaras de compensação realizam duas funções primordiais pois, tentam assegurar a integridade financeira das transações a futuro, seja garantindo diretamente alguns contratos, seja estabelecendo um elaborado mecanismo auto-regulável, para manter a saúde das finanças de todos os seus associados, os agentes ou membros da compensação; e, como as câmaras de compensação tornam-se parte de todos os contratos a futuro, oferecem um meio muito simples e conveniente para seu ajuste e sua liquidação: a compensação por diferença ${ }^{35}$.

A liquidação por diferença ou compensação é possivel porque todos os contratos de uma mesma espécie são intercambiáveis para o mesmo mês de entrega, ou seja, especificam a quantida de exata de bens de qualidade pré-determinada. Isso permite ao vendedor isentar-se de entregar sua mercadoria, simplesmente liquidando por compensação a obrigação, ou seja, basta assumir a posição igual e oposta à da atual obrigação. Desta forma, um contrato para entrega anula-se com igual contrato para recebimento. Esse mecanismo de liquidação só é possivel dado a existência e interveniência da clearing.

A maioria dos contratos futuros são liquidados financeiramente, por compensação. No entanto, existe a possibilidade de liquidação por entrega fisica da mercadoria. Nestes casos a câmara de compensação facilita o processo, ao distribuir e alocar as entregas entre os compradores que se qualificarem, proporcionando mecanismos de baixo custo a essas entregas.

De forma simplificada, pode-se dizer que a clearing do mercado de futuros atua como a vendedora de todos os compradores e compradora de todos os vendedores, assegurando a todos o 
acerto e a liquidação de suas respectivas posições, segundo os termos de valores exatos dos negócios contratados. Num caso de inadimplência de algum dos membros da bolsa, a câmara de compensação assume a responsabilidade e honra o compromisso em nome do devedor. Geralmente, a clearing não assume compromissos de um cliente frente ao membro da bolsa (o cliente de uma corretora, por exemplo) limitando-se a cobrir eventuais problemas entre os próprios membros.

As câmaras de compensação podem ser um departamento especifico da bolsa, chamadas clearing departamental, ou uma empresa autônoma prestadora dos serviços de registro, liquidação e compensação. Este departamento ou empresa responde pelo completo cumprimento do contrato. É uma instituição independente da bolsa, com sócios majoritários de alta expressão patrimonial e financeira, como bancos e conglomerados.

\subsubsection{Central de Registros SIA}

A Central de Registros S/A (CENTRAL), é a clearing independente do sistema das bolsas de fisico que negociam com o CM-G, sendo, portanto, um dos agentes do processo de negociação do CM-G.

De acordo com seu Estatuto, "tem por objetivo registrar, compensar e garantir a liquidação de contratos de venda e compra de mercadorias realizados em mercados no disponivel, a termo e outros. Estes contratos são realizados na Bolsa de Cereais de São Paulo, ou em outras instituições similares com as quais a CENTRAL venha celebrar convênios sendo que as propostas de registros devem, obrigatoriamente, ser encaminhadas à CENTRAL pelos acionistas que integrem o quadro de membros registradores da CENTRAL".

A CENTRAL instituiu um Regulamento (CENTRAL DE REGISTROS S/A, "a") que visa “ordenar, disciplinar e manter um sistema operacional sobre negócios realizados em bolsa, com mer-

35 Franklin R. Edwards. "The Clearing Association in Futures Narket" in: The Joumal of Fulures Market. New York, NY, 1983. v.3, n4, p.370. 
cadorias, no mercado fisico ou no disponivel, através de normas e condições que disciplinam o registro, a compensação, a garantia e a liquidação dos contratos de venda e compra de mercadorias realizados no mercado disponivel, a termo e outros" (CENTRAL DE REGISTROS SIA, "b").

A Central de Registros S/A, no cumprimento dos seus objetivos, torna-se o principal agente garantidor do sistema e, conseqüentemente, o principal responsável pela redução do risco de inadimplência de ambas as partes, nas negociações do mercado fisico através do CM-G, revelando sua função e importância na operacionalização deste certificado.

Segundo SOBOLL (s.n.t) a consolidação das diferentes funções e a harmonia operacional dos diferentes agentes do mercado de commodities agropecuárias são conseguidos com o estabelecimento de um sistema de clearing independente, integrado por instituições financeiras, bolsas de fisico e futuro, instituições de seguro, empresas do agribusiness, corretores e especuladores/investidores do mercado. Através desse clearing estabelecem-se as condições fundamentais de confiabilidade e garantia no cumprimento dos contratos, com base em sistema de registro, compensação, administra ção de garantias e liquidação dos negócios realizados.

Além disso, com a participação dos vários setores como acionistas da clearing e, consequentemente, no seu Conselho de Administração, fica garantido o espaço para a defesa dos interesses de cada um deles, conferindo credibilidade a câmara frente ao mercado como um todo.

A proposta da Central de Registros era exatamente esta, pois ao agregar como acionistas os vários setores envolvidos no mercado de commodities agropecuárias, tornando-os, conseqüentemente, representantes em sua diretoria, teria credibilidade crescente no mercado o que facilitaria a ampliação do seu quadro de acionistas e/ou de titulares. 


\subsection{Seguro Garantia de Obrigaçōes Contratuais (Seguro GOC) ${ }^{36}$}

Todo contrato de CM-G exige uma Carta de Fiança Bancária ou Apólice de Seguro Garantia para dar suporte à operação. Segundo PANHOCA (1996), "a carta de fiança poderá ser do próprio banco Membro Registrador, ou ainda, de outro banco onde 0 emitente-vendedor tenha conta bancária, e será "internada ${ }^{\text {n37 }}$ no sistema da Central de Registros S/A por um de seus Membros Registradores. Esta fiança ou apólice de seguro garante a qualidade, a data de entrega e 0 armazenamento da mercadoria nos exatos termos do oferecido e compromissado no corpo do $C M-G^{n}$.

O Seguro Garantia de Obrigações Contratuais (Seguro GOC) tem como objetivo garantir o cumprimento dos contratos de execução, fornecimento de bens e prestação de serviços, bem como as licitações. Destina-se às empresas que, na condição de contratadas, estão obrigadas a garantir a seus clientes, que os contratos firmados, no que se refere a preços, prazos e demais especificações pactuadas, serão rigorosamente cumpridos.

Foi criado na década de sessenta e era destinado à construção civil como forma de garantir o término de contratos daquela modalidade. Em 1989 a Circular n² 26 da Superintendência de Seguros Privados (SUSEP) transformou-o em um instrumento semelhante à fiança bancária permitindo seu uso em operações como o CM-G. Como principal diferença, não é mais o banco quem corre o risco e sim a seguradora e o Instituto de Resseguros do Brasil (IRB) que se obrigam com o tomador para o cumprimento do contrato principal. Como o risco consiste na inadimplência do tomador, a seguradora deverá por principio acompanhar o cronograma fisicofinanceiro do empreendimento através de seus técnicos.

São as partes contratantes: i) tomador (empresa contratada, construtora, fornecedora ou prestadora de serviços que está sendo garantida); ii) segurado/beneficiário (empresa contratante

36 As informaçōes necessárias ao desenvolvimento deste item foram, em sua maior parte, prestadas alravés de entrevistas com os senhores Heraldo Panhoca, Roberto Mauri Cardoso e pelos representantes da Delgado \& Prada Consultoria e Administraçäo de Seguros, bem como, através de material impresso utilizado por essa última para informaçáo sobre o Seguro GOC aos seus cientes. 
do empreendimento, para qual está sendo prestada a garantia); e, iii) seguradora (empresa garantidora que através da emissão de apólice, assumirá a obrigação de principal pagadora em caso de inadimplência do contratado por parte do tomador.

O Seguro GOC pode ser utilizado por pessoa fisica desde que com um pré-aval do banco Membro Registrador da Central. Este pré-aval não tem custo e baseia-se na ficha cadastral do cliente. O banco não consta formalmente como avalista limitando-se a recomendar o cliente à seguradora que aceita fazer o seguro.

Entre as modalidades de Seguro GOC disponiveis no mercado, duas são adequadas a operacionalização do CM-G. A do Fornecedor de Bens e Mercadorias, especifica para o CMDG, quando a mercadoria está disponivel, e a do Adiantamento de Pagamento, dirigida para o CMFG, quando ocorre adiantamento de recursos para entrega futura da mercadoria. Suas aplicações são:

1. Fornecedor de Bens e Mercadorias - decorrente dos prejuizos do inadimplemento do contratado com relação às obrigações assumidas em contrato; $\mathrm{e}$,

2. Adiantamento de Pagamento - decorrente do inadimplemento do tomador (contratado) em relação aos adiantamentos concedidos pelo segurado (contratante) que não tenham sido liquidados na forma estabelecida em contrato.

No caso, o contratado é o produtor. É ele quem faz e paga o seguro que vai cobrir sua eventual inadimplência face ao contratante (uma trader por exemplo). No caso de frustração de safra e perda da colheita, o Seguro GOC garante a entrega do produto ao comprador do CM-G, permitindo que o contrato seja liquidado. No entanto, o produtor, a menos que tenha feito também um seguro de safra, não vai estar coberto. Neste caso, terá suas garantias executadas. Portanto, a função do Seguro GOC é garantir ao tomador do CM-G que o contrato será cumprido de acordo com o estabelecido, dando maior confiabilidade ao sistema de negociação de mercadorias através de certificados.

37 Introduzida. 
As taxas do seguro para mercadoria agricola também irão depender da análise do cadastro do tomador e variam de $2,5 \%$ a $3,5 \%$ linear ${ }^{38}$ para CMFG. No caso de operações com mercadoria disponivel, CMDG, podem ser negociadas reduções dessas taxas, de acordo com o prazo, e até ser estudada a possibilidade de utilização de taxas proporcionais ao período estipulado de cobertura (pró-rata).

Este seguro é calculado sobre o valor inicial do contrato e o prêmio, no caso das operações de soja e boi-gordo, è de até $130 \%$ do valor do contrato. Na prática, a clearingé a beneficiária do seguro e na sua função de administrar a garantia e liquidação dos negócios vai comprar o produto no mercado e debitar a seguradora através do banco. A cobertura destas apólices não se aplica a garantias financeiras, ou seja, ao pagamento de somas em dinheiro provenientes de créditos comerciais em todas as suas formas, tais como: operações decorrentes de empréstimos bancários, vendas e prestações por sistemas de crediário ou qualquer transação similar. Em resumo, o objetivo deste seguro não é financeiro, não é para compensar ganhos ou prejuizos financeiros e sim repor um prejuizo material.

Os limites de garantia são fixados com base no cadastro do tomador, levando-se em conta a análise técnica, econômica e financeira da empresa e de seus acionistas. As empresas são classificadas de acordo com os critérios DUN/SERASA ${ }^{39}$. No caso de empresas de pequeno e médio porte é limitado a $100 \%$ da receita operacional liquida. Já no caso de empresas de grande porte, a $20 \%$ do patrimônio líquido.

A contra garantia ${ }^{40}$ é instrumento obrigatório para a realização do SGOC, ainda que seja necessária a constituição de garantia adicional. Estas serão sempre exigidas, a critério da segu-

39 A taxa cobrada pelo seguro, no caso de contratos agricolas, não é pró-rata para periodos menores que um ano. Isto é, é a mesma independentemente do periodo estipulado de cobertura se este for menor do que um ano. Para periodos maioresque um ano considera-se o método de cálculo de juros simples. Segundo a Delgado \& Prada, com o aumento da utilização deste seguro para operaçōes agricolas, é grande a possibilidade das taxas tornarem-se proporcionais.

30 Dun \& Bradstreet (DUN) e Centralização de Serviços dos Bancos SIA (SERASA) são empresas que a partir de um banco de informaçōes, tem condiçōes de orientar decisōes de crédito e avaliação de cadastros entre outros serviços.

* Este documento deve ser assinado pela empresa, representada por diretores com poderes de representação e, na qualidade de fiadores e principais pagadores, os dois maiores acionislas da empresa, com os respectivos cônjuges, se pessoa física, e através de representantes legais, se pessoa juridica, devendo esta estar lambém cadastrada. 
radora, quando recomendável ou quando o acúmulo de responsabilidade exceder o limite de garantia do tomador. Serão elas:

1. hipoteca de imóvel - válida somente para imóvel desembaraçado e livre de ônus, avaliado em órgão qualificado e devidamente registrado em Cartório de Registro de Imóveis;

2. penhor - válido para equipamentos estacionários e julgados de boa negociação, desde que livres de ônus, adequadamente identificados e registrados em cartório competente;

3. aval de empresa não ligada ao tomador, devendo contar com o devido cadastramento ${ }^{41} ; \mathrm{e}$

4. nota promissória, garantia fidejussória, certificado de depósito bancário e outras garantias aprovadas pelas partes.

A vantagem na utilização do Seguro Garantia de Operações Contratuais em relação à carta de fiança está principalmente no custo que representa para o emitente. Enquanto as cartas de fiança representam um custo de $4 \%$ a $6 \%$ do valor negociado, o SGOC representa entre $2,5 \%$ e $3,5 \%$ sobre $130 \%$ desse valor. Em geral, são vantajosos para operações mais longas, visto que são cobrados pelo período de um ano, como será apresentado nos resultados das simulações, na seqüência deste trabalho.

Com relação ao seguro da produção, as empresas de seguro privado continuam não demonstrando interesse em atuar no mercado de seguro agricola, devido ao alto risco presente neste tipo de atividade. Consideram que ao contrário de outros setores, os sinistros relacionados à produção agricola têm características de catástrofe, pois atingem muitas propriedades ao mesmo tempo. Desta forma, avaliam que o seguro da agricultura deveria ser feito pelo governo que teria, inclusive, meios tecnológicos de diminuir riscos de perdas, em determinadas culturas, inclusive através de zoneamento agricola (TSUNECHIRO et alii, 1996).

Assim, como alternativa para o seguro de produção, há o Programa de Garantia da Atividade Agropecuária (PROAGRO), que a partir da safra 1996/97, ficou vinculado ao zoneamento agricola elaborado pela Empresa Brasileira de Pesquisa Agropecuária (EMBRAPA) com restição das cobertu- 
ras para perdas causadas por granizo, tomba d'água, vendaval e seca, tornando mais acessivel o seguro para os produtores. No caso de arroz de sequeiro e feijão, a aliquota foi reduzida de $11,7 \%$ para $6,7 \%$, enquanto para soja e milho reduziu-se de $7 \%$ para $3,9 \%$. No caso de culturas irrigadas, a aliquota que era de $4,7 \%$ foi reduzida para $1,7 \%$ (BANCO CENTRAL DO BRASIL, 1996) ${ }^{42}$. Esses percentuais incidem sobre a soma do valor nominal de cada operação.

\subsection{Armazenagem}

A evolução de um mercado secundário de titulos de crédito de comercialização somente é possivel se, anteriormente, já ocorreu um desenvolvimento do mercado primário, para que este forneça o lastro e a garantia aos depósitos em mercadorias. O mercado secundário pode investir em títulos que estejam baseados em produtos depositados e garantidos, e movimentar recursos para financiar os produtos agrícolas através do mercado financeiro.

O mercado primário é onde estão os emitentes dos titulos, que são: a) os produtores depositantes das mercadorias; b) os serviços de comercialização que realizam a classificação e a armazenagem dos produtos; e, c) as armazenadoras que emitem os documentos de depósito das mercadorias.

Para cumprir os requisitos básicos de funcionamento, é importante que os equipamentos de comercialização sejam montados e operacionalizáveis conforme as normas e padrões de classificação e armazenagem dos produtos, além da necessidade de capacidade instalada para armazenagem.

A expansão do uso do CM-G, portanto, está na dependência da organização desse mercado primário, cujas limitações e potencialidades que oferece para viabilizar aquela expansão serão avaliadas nessa seção. $O$ objetivo aqui ë realizar um levantamento das formas de armazenagem de grãos e

"Neste caso poderá ser concedido um Limite de Garantia Combinado do avalista e do tomador

12 Resolução $n^{\circ} 2.294$, de 28.06.96 do Banco Ceniral do Brasil que dispöe sobre o zoneamento agricola, safra de verão 1996/97, redução de aliquota de adicional do PROAGRO e ajustes complementares para o Programa. 
caracterizar os equipamentos de comercialização em termos gerais, para as Regiões Centro-Oeste, Sudeste e Sul do pais.

O problema da armazenagem no Brasil ainda não foi solucionado de forma a dirimir as deficiências da capacidade estática localizadas em algumas áreas, principalmente graneleiros para as áreas de fronteira. Por outro lado, ainda é possivel aumentar os niveis de utilização dos armazéns disponiveis em muitas outras áreas do pais. Essa aparente contradição ${ }^{43}$ na organização da infraestrutura de armazéns dificulta uma análise com dados secundários agregados em nivel de região e mesmo unidade da federação, principalmente por eles serem escassos e pouco detalhados.

Por exemplo, o cadastro de unidades armazenadoras que fazia parte da atribuição da exCompanhia Brasileira de Armazenagem (CIBRAZEM) ${ }^{44}$ deveria ser obrigatório. Além disso, as unidades cadastradas, ao passarem a integrar o Sistema Nacional de Armazenamento (SINAZEM), estariam incluidas nos planos e programas governamentais destinados ao desenvolvimento do setor de armazenagem. Isso deveria dar credibilidade ao sistema e aos dados cadastrais. Mas, na prática, isso não ocorre. A dificuldade na própria conceituação e identificação dos diferentes tipos de unidades armazenadoras e os descredenciamentos que ocorrem de um periodo para outro, dificultam o acompanhamento sistemático dessas unidades. Uma outra dificuldade, inerente à rede de armazenagem atual, é a falta de regulamentação adequada que oriente depositante e depositário, e assegure a integridade dos produtos estocados.

Para a ex-Companhia de Financiamento da Produção (CFP) o problema das chamadas perdas de estoques em armazenagem sempre se caracterizou como de natureza crônica. Devido a uma legislação omissa e dispersa, a caracterização dos "desvios de estoques" se tornava dificil, pois os dispositivos inseridos nas tarifas dos armazenadores facilitavam a alegação de "quebra técnica" e os liberavam de indenizações. Os processos referentes às perdas em armazenagem (não indenizadas), tem trazido problemas na gestão do sistema.

13 Essa situação pode ser explicada como consequeuencia do deslocamento da agricultura, em função da sua evolução.

4. Desde 1991 a CIBRAZEM vem operando através de uma fusza com a Companhia Brasileira de Alimentos (COBAL) e a Companhia de Financiamento da Produçäo (CFP), sob o nơne de Companhia Nacional de Abastecimento (CONAB). 
O problema de perdas de estoques em armazenagem ilustra a dificuldade em se estabelecer critérios operacionais para um sistema de armazenagem, mesmo que se pretenda encaminhálo para um processo de privatização. 0 problema das "quebras técnicas", por perda na qualidade dos estoques, afeta a implantação de um regime de responsabilidade técnica nos armazéns e silos que permitam uma fiscalização eficaz. Esta ação poderia ser realizada pelas juntas comerciais que seria uma ação conjunta dos órgãos do governo ligados a um setor de controle dos amazéns e da Bolsa de Mercadorias.

Segundo LOPES (1994d), os serviços de armazenagem não têm qualidade em escala nacional devido, entre outras razões, aos contratos de depósito não equilibrados na preservação dos direitos de depositantes e depositários. Como não há tabelas de desconto de umidade e impureza confíá veis, o produtor ao depositar uma mercadoria não sabe quando e a que custo ele vai retirar sua mercadoria. A falta de fiscalização dos armazéns gerais por parte das juntas comerciais faz com que se generalize práticas lesivas ao interesse dos depositantes, como os descontos excessivos, a apropriação de parte da produção estocada para cobrir eventuais perdas e a cobrança de serviços onerosos na secagem e limpeza de grãos.

Utilizando os dados dos cinco principais produtos básicos (arroz, feijão, milho, trigo e soja), que representam cerca de $99 \%$ da produção de grãos comestiveis do pais, REIS (1994) calculou 0 desperdicio existente no ciclo produção/comercialização, para a safra 1994/95, em 12.134 mil tonela das, o que representou $15,3 \%$ da produção total. Grande parte dessa perda ocorre no sistema de armazenagem, fato que contraria não somente os requisitos para uma Politica de Segurança Alimentar, como um programa de reformas na comercialização de produtos agricolas e no crédito rural, trazendo insegurança e elevação dos custos para o emitente dos títulos como CM-G e CPR.

\subsubsection{A Situação da Capacidade de Armazenagem}

Do total da capacidade estática de armazenagem do Brasil (83.282 mil toneladas), 93,2\% está concentrada nas regiōes Centro-Oeste, Sudeste e Sul, com participações de 30,2\% (27.001 mil toneladas), 18,2\% (16.274 mil toneladas) e 44,8\% (40.006 mil toneladas) respectivamente (Tabela 6). Somente este fato já dá a essas regiōes uma grande importância dentro do Sistema Nacional de Armazenagem (SINAZEM), posto que elas contribuem com 87,4\% (77.252 mil toneladas) da produção de grãos no Brasil, segundo os dados da safra 93/94 do Levantamento Sistemático da Produção Agricola (LEVANTAMENTO, 1994) (Tabela 7). 
Tabela 6 - Capacidade estática dos armazéns cadastrados no SINAZEM conforme uso e posse, por unidade da federação das grandes regiões selecionadas, Brasil, outubro de 1994.

\begin{tabular}{|c|c|c|c|c|c|c|c|c|c|c|c|c|}
\hline \multirow[t]{3}{*}{ UF } & \multicolumn{2}{|c|}{ Oficiais } & \multicolumn{2}{|c|}{ Privadas } & \multicolumn{2}{|c|}{ Cooperativas } & \multicolumn{4}{|c|}{ Total por modalidade } & \multicolumn{2}{|c|}{ Total geral } \\
\hline & \multirow{2}{*}{$\begin{array}{l}\text { Convenc. } \\
\text { Capacid. }\end{array}$} & \multirow{2}{*}{$\begin{array}{c}\text { Granel } \\
\text { Capacid. }\end{array}$} & \multirow{2}{*}{$\begin{array}{l}\text { Convenc. } \\
\text { Capacid. }\end{array}$} & \multirow{2}{*}{$\begin{array}{c}\text { Granel } \\
\text { Capacid. }\end{array}$} & \multirow{2}{*}{$\begin{array}{l}\text { Convenc. } \\
\text { Capacid. }\end{array}$} & \multirow{2}{*}{$\begin{array}{c}\text { Granel } \\
\text { Capacid. }\end{array}$} & \multicolumn{2}{|c|}{ Convenc. } & \multicolumn{2}{|c|}{ Granel } & \multirow[b]{2}{*}{$\mathrm{N}^{0}$} & \multirow[b]{2}{*}{ Capacid. } \\
\hline & & & & & & & $\mathrm{N}^{0}$ & Capacid. & $\mathrm{N}^{0}$ & Capacid. & & \\
\hline C.Oeste & 1.134 .444 & 1.307 .458 & 7.532 .847 & 13.501 .348 & 918.013 & 2.607 .178 & 2.035 & 9.585 .304 & 978 & 17.415 .98 & 3.013 & 27.001 .288 \\
\hline DF & 47.601 & 25.600 & 70.745 & 22.350 & 5.998 & 33.720 & 29 & 124.344 & 9 & 81.670 & 38 & 206.014 \\
\hline GO & 532.115 & 593.038 & 3.678 .208 & 5.858 .001 & 311.674 & 1.059 .058 & 890 & 4.521 .997 & 319 & 7.510 .097 & 1.209 & 12.032 .094 \\
\hline MT & 330.315 & 369.300 & 2.894 .256 & 4.830 .185 & 364.431 & 576.440 & 766 & 3.589 .002 & 358 & 5.775 .925 & 1.124 & 9.364 .927 \\
\hline MS & 224.413 & 319.520 & 889.638 & 2.790 .812 & 235.910 & 937.960 & 350 & 1.349 .961 & 292 & 4.048 .292 & 642 & 5.398 .253 \\
\hline Sudeste & 2.180 .412 & 1.073 .759 & 6.018 .142 & 3.619 .089 & 1.903 .800 & 1.479 .254 & 1.487 & 10.102 .354 & 510 & 6.172 .102 & 1.997 & 16.274 .456 \\
\hline MG & 458.077 & 419.420 & 1.368 .613 & 1.534 .615 & 451.830 & 462.662 & 646 & 2.278 .520 & 198 & 2.416 .697 & 844 & 4.695 .217 \\
\hline ES & 78.000 & - & 195.765 & 12.800 & 56.374 & 7.200 & 88 & 330.139 & 4 & 20.000 & 92 & 350.139 \\
\hline RJ & 84.697 & - & 152.571 & 108.623 & 32 & - & 63 & 237.300 & 11 & 108.623 & 74 & 345.923 \\
\hline$S P$ & 1.559 .638 & 654.339 & 4.301 .193 & 1.963 .051 & 1.395 .564 & 1.009 .392 & 690 & 7.256 .395 & 297 & 3.626 .782 & 987 & 10.883 .177 \\
\hline Sul & 558.323 & 1.867 .626 & 7.677 .184 & 13.111 .464 & 3.877 .133 & 12.914 .691 & 3.882 & 12.112 .640 & 3.522 & 27.893 .78 & 7.404 & 40.006 .421 \\
\hline PR & 429.967 & 662.026 & 2.634 .811 & 4.883 .493 & 2.190 .584 & 6.414 .675 & 1.131 & 5.255 .362 & 1.021 & 11.960 .19 & 2.152 & 17.215 .556 \\
\hline SC & 23.240 & 126.500 & 710.016 & 1.071 .606 & 439.572 & 575.357 & 640 & 1.172 .828 & 364 & & 1.004 & 2.946 .291 \\
\hline RS & 105.116 & 1.079 .100 & 4.332 .357 & 7.156 .365 & 1.246 .977 & 5.924 .659 & 2.111 & 5.684 .450 & 2.137 & 14.160 .12 & 4.248 & 19.844 .574 \\
\hline Subtotal & 3.873 .179 & 4.248 .843 & 21.228 .173 & 30.231 .901 & 6.698 .946 & 17.001 .123 & 7.404 & $31,800.298$ & 5.010 & 51.481 .86 & 12.414 & 83.282 .165 \\
\hline Brasil & 4.940 .726 & 4.398.293 & 23.567 .029 & 31.301 .561 & 7.529 .135 & 17.544 .963 & 8.752 & 36.036 .890 & 5.159 & 53.244 .81 & 13.911 & 89.281 .707 \\
\hline
\end{tabular}

Fonte: COSTA \& TOSTA, 1995 p. 23 
Tabela 7 - Produção agricola de grãos e de fibras, por unidade da federação das grandes regiões selecionadas, Brasil, safra 1993/94 (em 1.000 t).

\begin{tabular}{|c|c|c|c|c|c|c|c|c|c|}
\hline \multirow[t]{2}{*}{ UF } & \multicolumn{6}{|c|}{ Produto } & \multicolumn{2}{|c|}{ Sub- total } & \multirow{2}{*}{$\begin{array}{c}\text { Total } \\
\text { Grãos+Fibra }\end{array}$} \\
\hline & Arroz & Feijão & Milho & Soja & Trigo & Outros ${ }^{1}$ & Grãos & Fibras $^{2}$ & \\
\hline C.Oeste & 1.535 & 205 & 5.511 & 9.939 & 84 & 142 & 17.418 & 270 & 17.688 \\
\hline DF & 3 & 9 & 87 & 2 & - & 1 & 103 & - & 103 \\
\hline GO & 467 & 142 & 3.098 & 2.306 & 14 & 86 & 6.112 & 101 & 6.213 \\
\hline MT & 839 & 26 & 1.172 & 5.241 & - & 51 & 7.330 & 97 & 7.427 \\
\hline MS & 226 & 28 & 1.154 & 2.390 & 70 & 4 & 3.873 & 72 & 3.945 \\
\hline Sudeste & 1.070 & 693 & 7.302 & 2.392 & 54 & 7.355 & 13.784 & 324 & 14.108 \\
\hline MG & 645 & 380 & 3.811 & 1.220 & 20 & 1.198 & 7.274 & 79 & 7.353 \\
\hline ES & 85 & 57 & 226 & - & - & 439 & 808 & - & 808 \\
\hline RJ & 64 & 7 & 54 & - & - & 16 & 141 & - & 141 \\
\hline$S P$ & 276 & 249 & 3.211 & 1.172 & 34 & 618 & 5.561 & 245 & 5.806 \\
\hline Sul & 5.140 & 1.012 & 15.903 & 11.286 & 2.235 & 712 & 36.289 & 419 & 36.708 \\
\hline PR & 242 & 499 & 7.849 & 5.410 & 1.168 & 303 & 15.471 & 419 & 15.890 \\
\hline SC & 667 & 345 & 3.303 & 433 & 95 & 23 & 4.868 & - & 4.868 \\
\hline RS & 4.231 & 168 & 4.751 & 5.443 & 972 & 386 & 15.950 & - & 15.950 \\
\hline Sub-total & 7.745 & 1.910 & 28.716 & 23.617 & 2.373 & 8.209 & 67.491 & 1.013 & 68.504 \\
\hline Brasil & 10.630 & 3.348 & 32.136 & 24.690 & 2.374 & 4.074 & 77.252 & 1.537 & 78.788 \\
\hline
\end{tabular}

A região Sul, além de concentrar a maior capacidade estática de armazenagem, como vimos acima, é também a região onde ocorre a maior participação das cooperativas na armazenagem a granel, principalmente nos Estados do Paraná e do Rio Grande do Sul, respectivamente, com 6.415 mil e 5.925 mil toneladas de capacidade (Tabela 6). 
As entidades privadas, por sua vez, predominam nos armazéns a granel das regiōes CentroOeste e Sul com, respectivamente, 13.501 mil e 13.111 mil toneladas de capacidade estática. Apenas estas duas regiōes, para a modalidade de armazenagem a granel de entidade privada, representam $29,8 \%$ do total da capacidade estática do pais.

Confrontando-se os dados de capacidade estática e dinâmica com a produção de grãos, 0 balanço obtido fornece uma idéia do déficit potencial de capacidade armazenadora nas regiões selecionadas. A capacidade dinâmica é definida como sendo 1,5 vezes a capacidade estática dos arma zéns. Ela é uma medida que deve levar em conta os periodos de safra e entressafra e de escoamento/comercialização dos produtos que permite aquele índice de rotação.

Para a produção de grãos I (arroz e feijão) que exige armazenagem convencional (em sacaria), o balanço já poderia ser positivo para todas as regiōes, somente considerando-se a capacidade estática (Tabela 8). Esse excedente de armazenagem convencional para produtos ensacados já vem ocorrendo há algum tempo no SINAZEM. A situação é menos favorável quando avalia-se a capacidade de armazenagem à granel para milho, soja e trigo (grãos II), cujo balanço mostrou-se negativo para a região Sudeste, com déficit de $\mathbf{4 9 0}$ mil toneladas (Tabela 9). Fazendo-se o cálculo separadamente para cada estado da região Sudeste, resultou em déficit de 1.426 mil toneladas de armazém graneleiro no estado de Minas Gerais, e 196 mil toneladas no estado do Espirito Santo.

Tabela 8 - Capacidade estática e dinâmica para armazenagem convencional, por grandes regiōes do Brasil (em 1.000 t)

\begin{tabular}{lcccc}
\hline \multirow{2}{*}{ Região } & \multicolumn{2}{c}{ Capacidade Convencional } & Produção de Grãos I & Balanço (A - B) \\
\cline { 2 - 4 } & Estática & Dinámica $^{2}(\mathrm{~A})$ & (B) & \\
\hline C.Oeste & 9.585 & 14.377 & 1.740 & 12.637 \\
Sudeste & 10.102 & 15.153 & 1.763 & 13.390 \\
Sul & 12.113 & 18.169 & 6.152 & 12.017 \\
Brasil & 36.037 & 54.055 & 13.978 & 40.077 \\
\hline
\end{tabular}

Fonte: Cálculos baseados nas Tabelas 1 e 2 .

${ }^{1}$ Grãos I = arroz e feijão.

${ }^{2}$ A capacidade dinâmica é definida com sendo 1,5 vezes a capacidade estática dos armazéns. 
Tabela 9 - Capacidade estática e dinâmica para armazenagem à granel, por grandes regiões do Brasil (em $1.000 t)$

\begin{tabular}{lcccc}
\hline \multirow{2}{*}{ Região } & \multicolumn{2}{c}{ Capacidade à Granel } & Produção de Grãos $\|^{1}$ & Balanço (A-B) $^{n}$ \\
\cline { 2 - 5 } & Estática & Dinàmica $^{2}(\mathrm{~A})$ & (B) & \\
\hline C.Oeste & 17.416 & 26.124 & 15.534 & 10.590 \\
Sudeste & 6.172 & 9.258 & 9.748 & $(490)$ \\
Sul & 27.894 & 41.841 & 29.424 & 12.417 \\
Brasil & 53.245 & 79.867 & 59.200 & 20.667 \\
\hline
\end{tabular}

Fonte: Cálculos baseados nas Tabelas 1 e 2 .

${ }^{1}$ Grãos $\|$ = milho, soja e trigo.

${ }^{2} \mathrm{~A}$ capacidade dinâmica è definida com sendo 1,5 vezes a capacidade estática dos armazéns.

Essas avaliações gerais apenas dão uma idéia de alguma deficiência de armazenagem em nivel agregado, mas é importante lembrar que elas ocorrem em nivel local, mesmo numa região ou estado que não apresentou falta de capacidade de armazenagem geral.

Por outro lado, existe a necessidade de reformas na rede de armazenagem que devem levar em conta, segundo LOPES (1994d, p.47), os seguintes aspectos:

a) "prosseguimento das reformas de privatização no setor de armazenamento público, hoje paralisa das. 0 governo iniciou a privatização de grande parte da extinta Cibrazem. 0 plano inicial era privatizar cerca de 450 armazéns, de um total de 550, aproximadamente (há informações de que foram privatizados cerca de 180 );

b) melhoria da tecnologia de armazenamento. As principais atribuições da CONAB, em combinação com o Centreinar (que inexplicavelmente se encontra desativado), está nas áreas de desenvolvimento tecnológico, criação de normas, manuais de procedimentos e rotinas de inspeção, formação de mão-de-obra técnica qualificada (e não de operação fisica e econômica de unidades amazenadoras); 
c) investimento em pesquisas prioritárias nas áreas de comercialização e armazenagem;

d) estudo de eficiência dos serviços de classificação, pois sabe-se que embora o serviço arrecade taxas suficientes para oferecer um serviço de qualidade, os recursos vão para os estados, que por sua vez não os repassam ao serviço;

e) estudo do sistema de informações de mercado. Este é um serviço-chave para a comercialização, e no Brasil os produtores não têm acesso à informação independente. A informação que o produtor obtėm é já viciada pelos intermediários;

f) estudos dos padrões dos serviços de pulverização, limpeza, secagem e embalagem oferecidos aos usuários, inclusive de oportunidades de mercado interno e externo, com recomendações de aprimoramento e melhoria de qualidade dos mesmos;

g) reforma da Lei $n^{0} 1.102$ - lei de armazéns gerais. A lei no 1.102 necessita de atualização, principalmente no tocante ao papel das juntas comerciais na atuação direta e na responsabilidade pela fiscalização. Isso não pode ser feito só pelo governo federal e pelos estados;

h) estabelecimento de documentos de depósitos uniformes e negociáveis. A Lei $n^{\circ} 102$ criou o recibo de depósito (RD), o conhecimento de depósito (CD) e o warrant $(\mathrm{W})$. Os armazéns gerais podem emitir os três. As cooperativas, que não podem emitir W nem CD e são responsáveis por grande parte da comercialização de grãos, emitem o certificado de depósito e o recibo de depósito;

i) busca de solução para o problema das "quebras técnicas" e realização de pesquisas para determinar parâmetros admissiveis. Esse problema já é conhecido tecnicamente, e é possivel mediar as quebras técnicas tornando-as admissiveis; $e$,

j) implantação de regime de responsabilidade técnica (RT) nos armazéns gerais e silos. Esse regime permitiria a assistência técnica de profissionais às armazenadoras e a fiscalização do exercício 
profissional de RT junto às armazenadoras. A conservação de grãos e produtos agricolas requer conhecimentos cientificos e tecnológicos, indispensáveis à atividade armazenadora."

Essas reformas podem ser conduzidas de maneira a chegar a um processo de autoregulamentação do setor de armazenamento, com a implementação de selos de qualidade como garantia da oferta de bons serviços no setor e a parceria de programas oficiais com o setor privado.

O desenvolvimento e consolidação dos mercados de títulos depende do bom funcionamento do setor de armazenagem, que apresenta no Brasil problemas diversos como os apresentados acima. No entanto, a necessidade de credenciamento dos amazéns pelo banco Membro Registrador e posterior cadastramento dos mesmos na clearing, como exige a operacionalização do $\mathrm{CM}-\mathrm{G}$, representaria para esse setor uma oportunidade de adequação à uma nova realidade comercial. A medida que os armazéns fossem sendo cadastrados haveria maior transparência sobre a qualidade da prestação de serviços e criação de um mercado competitivo de armazenagem (SOBOLL, 1994). Desta forma, se por um lado as deficiências no setor de armazenagem dificultam o desenvolvimento do mercado de titulos, por outo, a criação e o lançamento pela iniciativa privada de titulos agricolas podem levar às reformas necessárias nesse setor, melhorando sua qualidade em todo 0 pais, o que beneficiaria todo 0 agribusiness. 


\section{ANÁLISE COMPARATIVA DO CM-G EM RELAÇÃO À CPR E AO SNCR}

A proposta deste item é comparar as características do CM-G com relação a CPR e conhecer qual seria o custo financeiro para o produtor de acordo com a opção feita para a obtenção dos recursos de financiamento para o custeio da produção.

\subsection{Comparação das características do CM-G e da CPR}

O Certificado de Mercadoria com Emissão Garantida, CM-G, lançado pela Bolsa de Cereais de São Paulo em 26/07/93, e a Cédula de Produto Rural, CPR, proposta pelo Banco do Brasil e criada pela Lei $n^{\bullet} 8.929$, de 22/08/94 são dois exemplos de titulo agricola que passaremos a comentar comparativamente a seguir.

Tabela 10 - Estrutura comparativa básica do CM-Ge da CPR.

(continua)

\begin{tabular}{|c|c|c|}
\hline & $\mathrm{CM}-\mathrm{G}$ & CPR \\
\hline Definição & $\begin{array}{l}\text { É um titulo mercantil, não endos- } \\
\text { sável. Um contrato de compra e } \\
\text { venda, representando fielmente a } \\
\text { existência / promessa e a quali- } \\
\text { dade do produto oferecido, e de } \\
\text { livre negociação entre as partes. }\end{array}$ & $\begin{array}{l}\text { É um título civil, líquido e certo, } \\
\text { endossável (com cláusula "a or- } \\
\text { dem") e exigivel pela quantidade } \\
\text { e qualidade do produto nela pre- } \\
\text { visto. }\end{array}$ \\
\hline
\end{tabular}


Tabela 10 - Estrutura comparativa básica do CM-G e da CPR.

(continua)

\begin{tabular}{|c|c|c|}
\hline & CM-G & CPR \\
\hline Versões & $\begin{array}{l}\text { Está disponivel em duas versões: } \\
\text { 1. Certificado de Mercadoria En- } \\
\text { trega Física Disponivel Garantida } \\
\text { - CMDG (tem como função a } \\
\text { comercialização), } \\
\text { 2. Certificado de Mercadoria - } \\
\text { Entrega Fisica Futura Garantida - } \\
\text { CMFG (além de ser um instru- } \\
\text { mento de comercialização a futu- } \\
\text { ro, permite a obtenção de crédito } \\
\text { antes do plantio da safra). }\end{array}$ & $\begin{array}{l}\text { Esta disponivel apenas na versão } \\
\text { "futura", ou seja, destina-se à } \\
\text { formalização de promessa de } \\
\text { compra e venda de produtos ru- } \\
\text { rais para a entrega futura, permi- } \\
\text { tindo a obtenção do capital de } \\
\text { giro necessário ao desenvolvi- } \\
\text { mento da atividade rural. }\end{array}$ \\
\hline Contrato & $\begin{array}{l}\text { Embasado no código civil e co- } \\
\text { mercial. }\end{array}$ & $\begin{array}{l}\text { Inspirada nas cédulas de crédito } \\
\text { rural e industrial, estando sujeita } \\
\text { as normas do direito cambial. }\end{array}$ \\
\hline Emissão & $\begin{array}{l}\text { Pode ser emitido por qualquer } \\
\text { pessoa fisica ou juridica detento- } \\
\text { ra da titularidade da mercadoria. }\end{array}$ & $\begin{array}{l}\text { Sua emissão é restrita ao produ- } \\
\text { tor rural e suas cooperativas. }\end{array}$ \\
\hline
\end{tabular}


Tabela 10 - Estrutura comparativa básica do CM-G e da CPR.

(continua)

\begin{tabular}{|c|c|c|}
\hline & $C M-G$ & CPR \\
\hline Utilização & $\begin{array}{l}\text { Pode ser udilizado para a comer- } \\
\text { cialização de produtos de origem } \\
\text { animal, vegetal e mineral. Pode } \\
\text { também ser utilizado pela indús- } \\
\text { tria de transformação para pro- } \\
\text { dutos de origem animal, vegetal e } \\
\text { mineral. }\end{array}$ & $\begin{array}{l}\text { Destina-se exclusivamente à pro- } \\
\text { dutos rurais como quaisquer pro- } \\
\text { dutos produzidos no âmbito do } \\
\text { produtor ou sua cooperativa, seja } \\
\text { ele vegetal ou animal. }\end{array}$ \\
\hline Endosso & $\begin{array}{l}\text { Não é endossável, ficando custo- } \\
\text { diado na agência bancária emis- } \\
\text { sora, que emite a autorização da } \\
\text { sua venda diretamente à clearing. }\end{array}$ & $\begin{array}{l}\text { É endossável, a CPR original fica } \\
\text { custodiada na agência bancánia e } \\
\text { o certificado de custódia fica na } \\
\text { posse do comprador }\end{array}$ \\
\hline Mercado & $\begin{array}{l}\text { Pode ser renegociado, ou seja, } \\
\text { revendido, observado o prazo de } \\
\text { validade da classificação e arma- } \\
\text { zenagem. }\end{array}$ & $\begin{array}{l}\text { Por ser endossável, admite sel } \\
\text { renegociado. }\end{array}$ \\
\hline
\end{tabular}


Tabela 10 - Estrutura comparativa básica do CM-Ge da CPR.

(continua)

\begin{tabular}{lll}
\hline & CM-G & CPR \\
\hline Negociaçãol & Deve ser obrigatoriamente nego- & Não é necessariamente negocia- \\
Comercializa & ciado e renegociado em bolsa, o & do em bolsa, podendo ser nego- \\
ção & que permite um controle do volu- & ciado também em "mercado de \\
& me de produtos efetivamente ne- & balcão", o que dificulta o contole \\
& gociado comparativamente ao & do volume efetivo de produto ne- \\
& número de "giros", dando trans- & gociado. Desta forma, a transpa- \\
& parência à comercialização, cri- & rência nem sempre ocorre. \\
& ando, portanto, condições favorá- & \\
& veis à auto-regulação do merca- & \\
& do. & \\
& Não há informações sobre a pos- & De acordo com as informações \\
Vinculação & sibilidade do CM-G poder ser vin- & disponiveis, a CPR pode ser vin- \\
em garantia & culado em garantia para adian- & culada em garantia para o ACC, \\
& tamento de contrato de câm- & adiantamento de contrato de \\
& bio(ACC). & câmbio, possibilitando o aumento \\
& no volume de adiantamento, an- \\
& & tes limitado de acordo com o pa- \\
& trimônio liquido do exportador.
\end{tabular}


Tabela 10 - Estrutura comparativa básica do CM-G e da CPR.

(conclusão)

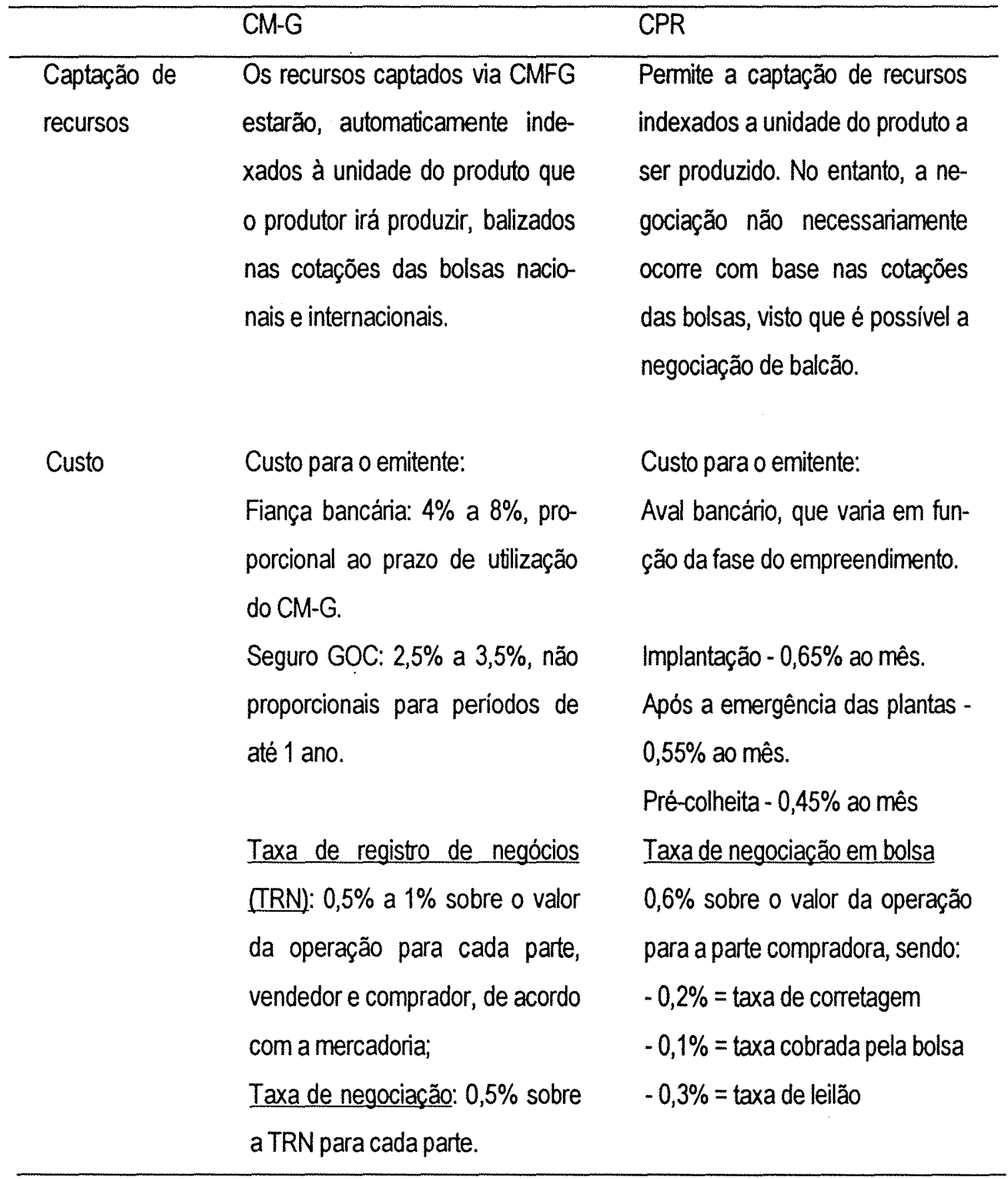

Fonte: Dados da pesquisa. 
Os dois titulos têm em comum a grande inovação de conferir ao produtor rural a condição de emissor do título de comercialização de seus produtos, hoje atribuição exclusiva da indústria, através da nota promissória rural/duplicata rural, e dos bancos, via cédula de crédito rural e cédula de crédito industrial.

O CMFG e a CPR, por serem titulos de compra e venda de mercadorias para entrega futura funcionam como instrumento de captação de recursos, ou seja, permitem o levantamento de capital de giro para o produtor custear a atividade que está sendo desenvolvida, com entrega do produto vendido após a sua colheita - o produtor capta, por partes, no momento e volume adequados, os recursos necessários para tocar a produção.

Os recursos captados através desses títulos estarão automaticamente indexados à unidade do produto, ponto que vem ao encontro das reivindicações do setor rural no sentido de compatibilizar a captação de recursos para crédito rural e a variação dos preços dos produtos.

No entanto, para que o mercado de titulos agropecuários se fortaleça e cresça no Brasil, é indispensável elevado nivel de confiança ente as partes, sendo fundamental, portanto, haver garantias de que o que foi contratado seja cumprido. Além disso, é necessário um mercado transparente.

A seguir, comentaremos alguns pontos onde os titulos em questão se diferenciam.

\section{Garantias}

Neste caso, a pretensão desses títulos é possuir garantias efetivas, simples e de reduzido custo de formalização, mas que não podem deixar de serem exigidas neste tipo de operação. As garantias a serem oferecidas pelo emitente são basicamente as mesmas, diferindo no custo e simplicidade de formalização. 
Nos dois casos, quando emitidos via instituição financeira (imprescindivel no caso do $\mathrm{CM}-\mathrm{Ge}$ alternativo no caso da CPR), a mesma exigirá garantias do emitente, considerando o risco/cliente envolvido, podendo inclusive, segundo seu critério, não emibir o titulo. Decidida a emissão, a instituição financeira cobrará fiança/aval do emitente. No caso do CM-G esse custo deve variar entre $4 \%$ a $8 \%$ ao ano, proporcional ao prazo de fiança, ou seja, ao prazo de utilização do certificado. Admite também o Seguro GOC que varia de $2,5 \%$ a 3,5\% ao ano. No caso da CPR o custo do aval dado pelo Banco do Brasil varia em função da fase do empreendimento: $0,65 \%, 0,55 \%$ e $0,45 \%$ ao mês.

No caso do $C M-G$, o banco é co-responsável do emitente o que se constitui numa garantia para o comprador de entrega fisica do produto. Além da instituição financeira, do vendedor e do comprador, ainda no caso do $\mathrm{CM}-\mathrm{G}$, fazem parte do processo de negociação, como co-obrigados, os seguintes agentes:

- o armazenador - fiel depositário;

- a clearing ${ }^{45}$ do sistema e seus membros registradores;

- a bolsa e seus corretores oficiais; $e$,

No caso da CPR quando emitida via instituição financeira, tem garantia de entrega fisica do produto, deve-se salientar que a mesma poderá ser emifida e negociada pelas partes compradora e vendedora que decidirão todas as condições da negociação, entre as quais as garantias a serem exigidas, sem a intermediação de quaisquer instituição, apenas respeitando a legislação especifica. A contribuição com relação aos contratos já existentes, como por exemplo os do setor citricola ou da Associação Nacional dos Exportadores de Cereais - ANEC, se dá na padronização do contrato, que tem registro na CETIP (Central de Custódia e de Liquidação Financeira de Títulos Privados) acompanhada da legislação especifica.

\footnotetext{
15 A "cleaning é um dos principais agentes garantidores do sistema. Ela é a administradora de garantias tanto do lado do comprador como do lado do vendedor. O CM-G só passa a existir oficialmente e suas garantias a ter validade, podendo então ser admitido para venda e revenda nos pregöes das botsas, quando devidamente registrado na "clearing". Para tanto só sāo aceitas entidades classificadoras credenciadas pelas bolsas e armazenadoras cadastrados pelo Membro registrador, ambas registradas junto a "clearing.
} 


\section{Garantia de entrega fisica do produto}

O mercado físico de produtos agropecuários, se confiável e organizado através de bolsa, constitui-se no elo de ligação entre o setor agrícola e os outros setores, tendo como ponto fundamental a garantia de entrega fisica do produto.

A comercialização via CM-G implica necessariamente na entrega fisica dos produtos negociados, o que é garantido pelos agentes co-obrigados, entre os quais a clearing e o membro registrador tem papel fundamental. No caso de não cumprimento por parte do emitente vendedor, a clearing garante ao comprador o produto adquirido, de acordo com as especificações preestabelecidas, comprando no mercado e debitando ao membro registrador ou seguradora. No caso da CPR quando emitida via instituição financeira, como o Banco do Brasil, há garantia de entrega física do produto negociado.

A titulo de exemplo da importância da garantia de entrega física do produto negociado, podemos citar o caso de interligação entre o produtor e a agroindústria. Consideremos o caso de um produtor de rações que decide comprar soja para entrega futura. Quando ele faz isso, está pensando, ente outras coisas, em garantir o abastecimento da matéria-prima no momento necessário, ganhar em termos de preço do produto, melhorar o nivel de utilização de seus silos, ou mesmo redimensionar sua capacidade de armazenamento, reduzindo seus custos. Portanto, o comprador deve ter a certeza de que receberá o produto comprado de acordo com o especificado, pois é com estes dados que ele vai trabalhar para planejar a sua produção. Desta forma, se no momento da entrega esse produtor de ra ções não receber a soja comprada, todo o seu planejamento será prejudicado, além das conseqüências sobre sua receita.

Além disso, este processo pode ter continuidade. Nestas condições, o comprador da matériaprima pode oferecer à venda o seu produto industrializado, já que tem por base a real garantia da entega fisica da matéria-prima adquirida, podendo desta forma planejar o seu processo produtivo. 0 produto industrializado (ração) pode ser matéria-prima de um outro comprador, por exemplo um pro- 
dutor de frango e suino. Calcado no aumento da credibilidade do vendedor, tem-se uma significativa redução do custo de captação dos recursos financeiros.

Neste ponto, o CM-G tem um alcance maior, podendo interligar os vários setores envolvidos direta ou indiretamente com a matéria-prima agricola, sempre através do mesmo instrumento de negociação. A diferença básica, até o momento, é que a emissão da CPR é restrita ao produtor rural e suas cooperativas e destina-se apenas à produtos rurais, produzidos no âmbito do produtor e suas cooperativas. Nada impede, no entanto, que a CPR possa ser reformulada para atender também a continuidade do processo, ou seja, passe a poder ser emitida também pelos detentores das mercadorias que vão ser produzidas ao longo da cadeia.

\section{Transparência}

Entre os especialistas em comercialização, é consenso que o mercado de títulos agricolas só se consolida a partir da constituição de um mercado de físico bem organizado o que requer, entre outros, divulgação transparente das operações/cotações e um sistema de classificação e armazenagem confiável. Desta forma, as operações em bolsa, e a centralização dos negócios através da clearing são de fundamental importância. No caso da CPR, só é possivel obter-se estatisticas sobre as cédulas avalizadas por bancos, que necessariamente devem ser registradas no CETIP, não sendo possivel obter-se informações sobre aquelas negociadas diretamente entre comprador e vendedor sem a intermediação da instituição financeira.

O CM-G neste ponto, por admitir exclusivamente operações via bolsa com registro em dearing, estará contribuindo para o desenvolvimento desse mercado. A CPR também é negociada em bolsa, mas abre também a possibilidade de negociação de balcão, que carece de transparência.

Discute-se neste ponto, que a cada operação de compra e venda, via bolsa e sem a possibilidade de endosso, haverá cobrança de comissões o que encareceria muito as transações, e que isso seria incompativel/insustentável no caso de produtos agricolas. No entanto, com o desenvolvimento do 
mercado e aumento da liquidez dos títulos ocorre consequentemente uma redução do risco, fazendo cair o custo da fiança/aval e do seguro como também os custos de corretagens e taxas.

\subsection{Resultado financeiro para o produtor na utilização do CM-G, da CPR e do SNCR}

Uma das maiores preocupações com relação ao negócio agricola é a de assegurar sua viabilidade econômica. Portanto, quando se discute crédito rural ou outras formas de financiamento, esta questão não pode ser esquecida. Ou seja, que a equação receita menos custo seja positiva. Este item foi desenvolvido sob esse enfoque e será abordado a partir do resultado das simulações de contratos equivalentes - custeio tradicional pelas regras do SNCR, CPR e CM-G, de custeio de soja não imigada.

\subsubsection{O Produto Soja}

Para este estudo escolheu-se trabalhar com o produto soja. Esta escolha se deve, em primeiro lugar, à elevada participação de contratos efetuados com CM-G (Tabelas 11 e 12) e CPR (Tabela 13) tanto no número quanto no valor negociado, nos anos de 1994, 1995 e 1996. Em segundo lugar, ao fato de constituir-se em uma commodity. Em terceiro lugar à importância que alcança na produção nacional de grãos. Concentrada no Centro-Sul, na safra $93 / 94$ a soja representou $34,99 \%$ do total de grãos produzidos. Determinou também a escolha desse produto o fato de dar origem a uma cadeia agroalimentar que interliga vários setores como o de produção, comercialização, exportação e indústrias.

Do total de negociações com o CM-G, nos períodos considerados nas Tabelas 11 e 12, a participação da soja em grão e seus derivados representou, respectivamente, $32,22 \%$ e $31,09 \%$ do valor total. No caso das operações com CPR, os negócios com soja em grão representaram 70,20\% (Tabela 13). 
A soja em grão negociada através do CM-G e da CPR seguem a seguinte especificação, padrão para a exportação:

- mercadoria : soja brasileira em grão (feijão soja), a granel;

- tipo único: exportação/ANEC (Cl - 16)

- padrão: Concex

- características: umidade - máximo de $14 \%$

impurezas - máximo de $1 \%$

avariados - máximo de $8 \%$ (estes, com até $5 \%$ de ardidos, $10 \%$ de grãos verdes e $30 \%$ de grãos quebrados)

Tabela 11 - Resumo das operações com CM-G efetuadas entre 26/07/93 e 31/12/94

\begin{tabular}{|c|c|c|c|c|c|c|}
\hline \multirow[t]{2}{*}{ Mercadoria } & \multirow{2}{*}{$\begin{array}{l}\text { Número de } \\
\text { Certificados }\end{array}$} & \multirow[t]{2}{*}{ Volume } & \multirow[t]{2}{*}{ Un. } & \multicolumn{2}{|l|}{ Valor } & \multirow{2}{*}{$\begin{array}{c}\text { Valor médio/Un. } \\
\text { (US\$) }\end{array}$} \\
\hline & & & & (US\$) & $(\%)$ & \\
\hline Outros & 170 & - & - & $20.977 .040,00$ & 14,96 & - \\
\hline Soja em grão & 107 & 3.005 .192 & $s c$ & $34.027 .553,00$ & 24,27 & 11,32 \\
\hline Borracha natural & 32 & 7.870 & $T$ & $17.891 .782,00$ & 12,76 & $2.273,42$ \\
\hline Madeira em pé - Pinus & 44 & 307.433 & $\mathrm{~m} 3$ & $15.487 .331,00$ & 11,05 & 50,38 \\
\hline Farelo de soja & 39 & 60.680 & $T$ & $11.143 .975,00$ & 7,95 & 183,65 \\
\hline Milho & 83 & 1.648 .061 & sc & $10.990 .150,00$ & 7,84 & 6,67 \\
\hline Algodão em pluma & 20 & 435.308 & $@$ & $9.992 .891,00$ & 7,13 & 22,96 \\
\hline Álcool hidratado & 25 & 33.321 & m3 & $9.495 .725,00$ & 6,77 & 284,98 \\
\hline Boi gordo & 79 & 212.527 & $@$ & $5.406 .825,00$ & 3,86 & 25,44 \\
\hline Café arábica-cons.int. & 16 & 41.552 & sc & $4.767 .830,00$ & 3,40 & 114,74 \\
\hline Total & 615 & $\longrightarrow$ & - & $140.181 .102,00$ & 100,00 & - \\
\hline
\end{tabular}

Fonte: CENTRAL DE REGISTROS S/A 
Tabela 12 - Resumo das operações com CM-G no ano de 1995.

\begin{tabular}{|c|c|c|c|c|c|c|}
\hline \multirow[t]{2}{*}{ Mercadonia } & \multirow{2}{*}{$\begin{array}{l}\text { Número de } \\
\text { Certificados }\end{array}$} & \multirow[t]{2}{*}{ Volume } & \multirow[t]{2}{*}{ Un. } & \multicolumn{2}{|l|}{ Valor } & \multirow{2}{*}{$\begin{array}{c}\text { Valor médio/Un } \\
\text { (US\$) }\end{array}$} \\
\hline & & & & (US\$) & $(\%)$ & \\
\hline Outros & 413 & 23.460 .359 & - & $3.534 .952,20$ & 7,35 & - \\
\hline Soja grão & 952 & 111.086 .867 & sc & $1.320 .622 .718,84$ & 27,46 & 11,89 \\
\hline Milho & $542^{\circ}$ & 170.673 .785 & $\mathrm{sc}$ & $1.228 .123 .373,28$ & 25,53 & 7,20 \\
\hline Boi gordo & 325 & 24.603 .129 & @ & $725.003 .158,53$ & 15,07 & 29,47 \\
\hline Algodão em pluma & 365 & 7.768 .493 & $@$ & $343.522 .870,03$ & 7,14 & 44,22 \\
\hline Madeira em pé - Pinus & 57 & 5.551 .432 & $\mathrm{~m} 3$ & $246.491 .307,98$ & 5,13 & 44,40 \\
\hline Fertilizante quimico & 151 & 576.106 & $T$ & $190.195 .412,59$ & 3,95 & 330,14 \\
\hline Óleo de soja & 12 & 168.750 & $\mathrm{~T}$ & $120.793 .032,60$ & 2,51 & 715,81 \\
\hline Óleo de mamona & 26 & 85.598 & $T$ & $114.227 .593,89$ & 2,38 & $1.334,47$ \\
\hline Café robusta Conillon & 126 & 703.699 & sc & $113.551 .643,70$ & 2,36 & 161,36 \\
\hline Óleo de soja degomado & 15 & 80.400 & $\mathrm{~T}$ & $53.843 .399,42$ & 1,12 & 669,69 \\
\hline Total & 2.984 & $\ldots$ & - & $4.809 .869 .730,36$ & 100,00 & - \\
\hline
\end{tabular}

Fonte: CENTRAL DE REGISTROS S/A

Tabela 13 - Resumo das operações com CPR efetuadas entre ago/94 e 21/10/96

\begin{tabular}{lrrrrrrr}
\hline \multicolumn{1}{r}{ Mercadoria } & $\begin{array}{c}\text { Número de } \\
\text { cédulas }\end{array}$ & Volume & Un. & \multicolumn{2}{c}{ Valor } & Valor médio/Un. \\
& 2 & 2.959000 & $\mathrm{I}$ & $1.000 .000,00$ & 0,89 & \multicolumn{1}{c}{$(\mathrm{R} \$)$} \\
\hline Álcool combustivel & 1 & 326.000 & $\mathrm{~kg}$ & $348.820,00$ & 0,31 & 1,07 \\
Algodão em pluma & 30 & 72.765 .000 & $\mathrm{~kg}$ & $12.000 .000,00$ & 10,71 & 0,16 \\
Arroz em casca & 6 & 1.442 .685 & $\mathrm{~kg}$ & $2.515 .215,00$ & 2,24 & 1,74 \\
Boi gordo & 1 & 15.000 & $\mathrm{~kg}$ & $15.000,00$ & 0,01 & 1,00 \\
Cacau & 158 & 4.171 .800 & $\mathrm{~kg}$ & $8.086 .615,57$ & 7,22 & 1,94 \\
Café arábica & 2 & 3.763 .508 & $\mathrm{~kg}$ & $5.000 .000,00$ & 4,46 & 1,33 \\
Cana-de-açúcar & 36 & 12.400 .000 & $\mathrm{I}$ & $2.650 .000,00$ & 2,36 & 0,21 \\
Leite In natura & 13 & 9.428 .520 & $\mathrm{~kg}$ & $778.580,00$ & 0,69 & 0,08 \\
Milho em grão & 791 & 517.588 .807 & $\mathrm{~kg}$ & $78.676 .923,45$ & 70,20 & 0,15 \\
Soja em grão & 1 & 1.333 .800 & $\mathrm{I}$ & $1.000 .350,00$ & 0,89 & 0,75 \\
Suco de laranja & 1.041 & & & - & $112.071 .504,02$ & 100,00 & -1 \\
Total & & & & & & & \\
\hline
\end{tabular}

Fonte: Banco do Brasil S/A, GT/BB - CPR. 
A soja é um produto com características de produção e comercialização relativamente homogêneas. Ou seja, é produzido majonitariamente por médios e grandes produtores que se utilizam de tecnologias modernas de produção, que permitem maior produtividade a menores custos, o que se deve em grande parte à concorrência que sofrem de outros paises.

No Brasil, a soja foi também um dos primeiros produtos que utilizaram mecanismos inovadores de financiamento, como o Contrato ANEC ou "soja verde", e hoje é o principal produto negociado através da CPR e do CM-G.

Ainterferência que o mercado interno de soja sofre da produção externa implicou num estreito relacionamento com os mecanismos de comercialização dos mercados futuros, principalmente da "Bolsa de Mercadorias de Chicago, a Chicago Board of Trade, onde são negociados os maiores volumes de soja do mundo, em negociações a futuro, sinalizando qual o preço que compradores e vendedores praticam para entrega em até 14 meses no futuro" (SCHOUCHANA, s.d. "b"). Assim que quem produz, negocia ou necessita de soja como matéria-prima no Brasil, deve estar sempre atento ao mercado internacional.

Na safra 1994/95, a produção brasileira de oleaginosas - soja, caroço de algodão e amendoim, alcançou $26.657,3$ milhões de toneladas dos quais $96,0 \%$ corresponderam a soja, enquanto que o algodão e o amendoim participaram, respectivamente com 3,5\% e 0,5\% do total. No caso da soja, os principais Estados produtores são Rio Grande do Sul (23,0\%), Paraná (22,0\%) e Mato Grosso $(21,0 \%)$ que responderam, nesta safra, por $66 \%$ da produção brasileira (LEVANTAMENTO SISTEMATICO DA PRODUÇÃO AGRICOLA, 1995).

Após a colheita, o sojicultor pode tanto depositar sua produção em armazéns (privados, cooperados, próprios ou industriais) como comercializá-la.

Três segmentos atuam no mercado da soja em grão no periodo que compreende 2 ou 3 meses antes do plantio e estende-se por 4 a 5 meses após a colheita: o setor de sementes, o setor de 
exportação e as indústrias. De acordo com ESTRAZULAS (1994), o setor de sementes participa com $4,9 \%$ da comercialização da soja em grão. 0 setor oferece preços ente 25 e $50 \%$ acima dos demais agentes de comercialização, dependendo da variedade e demanda preferencial, embora a expectativa da área a ser semeada influencie também os preços recebidos. Com a participação das cooperativas, indústrias e tradings, $20,4 \%$ da soja em grão é comercializada com o setor exportador, o qual destina sua aquisição sobretudo para Ásia e Europa.

Apesar do crescente consumo dos grãos de soja pelo setor industrial, as aquisições das indústrias de processamento não têm crescido no mesmo ritmo da produção nacional. Em 1992, as processadoras adquiriram $96,5 \%$ do volume produzido internamente, passando, em 1994, a adquirir $81,4 \%$ (Tabela 14). Amenor participação das aquisições industriais pode estar associada ao crescente número de tradings, as quais concorrem com as indústrias pelos mercados internacionais.

Tabela 14 - Aquisição e utilização da soja pelo setor moageiro, 1992-1994 (em toneladas)

\begin{tabular}{lrrr}
\hline Aquisiçäo e utilizaçäo da soja & \multicolumn{1}{c}{1992} & \multicolumn{1}{c}{1993} & \multicolumn{1}{c}{1994} \\
\hline Produção Nacional (P) & $14.937 .806,00$ & $19.214 .705,00$ & $22.694 .398,00$ \\
Aquisiçöes Industriais (A) & $14.421 .874,00$ & $17.021 .899,00$ & $18.474 .768,00$ \\
(AVP) \% & 96,55 & 88,59 & 81,41 \\
Revenda (R) & $1.264 .294,00$ & $1.936 .204,00$ & $1.947 .700,00$ \\
(R/A) \% & 8,77 & 11,37 & 10,54 \\
Transformação/ Moagem (T) & $13.317 .487,00$ & $15.156 .332,00$ & $16.435 .454,00$ \\
(T/P) \% & 89,15 & 78,88 & 72,42 \\
(T/A) \% & 92,34 & 89,04 & 88,96 \\
\hline
\end{tabular}

Fonte: ANUÁRIO ESTATISTICO DO BRASIL, IBGE ( 1994).

${ }^{1}$ Inclui perdas.

As indústrias de transformação são as principais consumidoras da soja em grão. Estas podem vende-los, estocá-los elou processá-los. As vendas podem se dar tanto no mercado externo, quanto no mercado interno. Nos anos 1992, 1993 e 1994, as vendas domésticas situaram-se ente 
$8,5 \%$ e $11,5 \%$ do total das aquisições das indústrias de processamento. No entanto, estes percentuais podem sofrer oscilações, a cada ano, pois submetem-se às condições do mercado internacional, assim como o volume estocado (Tabela 14).

Grande parte do volume adquirido pelas indústrias de processamento destinam-se à moagem, para obtenção do farelo (um dos principais itens da pauta de exportação brasileira) e óleo bruto. Em 1994, as indústrias de transformação adquiriram $81,4 \%$ da safra nacional, do qual $88,9 \%$ destinaram-se ao processamento (Tabela 14).

O óleo em estado bruto, ou degomado, pode ser comercializado no mercado externo ou interno. Estima-se que $70 \%$ da produção nacional de óleo bruto de soja seja comercializada internamente com diversos ramos industriais. Dessa parcela, a grande maioria é consumida pelas indústias alimentares, sobretudo as que respondem pelo processamento do óleo bruto: a produção de óleos refinados e margarinas. Já as exportações, apesar do crescente aumento, correspondem, em média, de $23 \%$ a $25 \%$ da produção doméstica, embora possam atingir percentuais maiores de acordo com a conjuntura dos mercados nacional e externo (FREITAS et alii, 1996)

Os preços mínimos da cultura da soja são diferenciados segundo as regiões produtoras. Para as Regiōes Sul, Sudeste e Centro-Oeste, à exceção de Mato Grosso, o preço minimo é, respectivamente para as safras 1995/96 e 1996/97, de $R \$ 8,14$ e $R \$ 8,88$ por saca de 60kg (TSUNECHIRO et alii, 1995 e 1996). Como a comercialização da soja é caracterizada pelo estreito vínculo com o mercado internacional, a importância do preço mínimo na formação dos preços internos é relativamente pequena.

Quanto ao crédito rural, a soja tem sido nas últimas safras diferenciada em relação aos demais produtos componentes da cesta básica, inclusive 0 algodão, por estar incluída no rol das culturas que contam com o menor limite de financiamento, ou seja de $R \$ 30.000,00$ por beneficiário para custeio e Empréstimo do Governo Federal sem Opção de Venda (EGF/SOV) (safra 1996/97). A taxa de juros é a mesma para as demais culturas contempladas pelo Programa, de 16\% ao ano para a safra $1995 / 96$ e de $12 \%$ ao ano para a safra 1996/97. 
A safra brasileira de soja ocorre, em maior parte, na entressafra internacional, ou seja num período de altas cotações no mercado externo (BARBOSA et alii, 1995). Conseqüentemente, é forte a disputa entre tradings e indústrias pela aquisição dessa commodity, sendo que as indústrias pagam um custo maior para manterem-se no mercado. Além disso, segundo CANZIANI (1995), a concorrência, pela matéria-prima, entre tradingse indústrias, tem gerado aumento nas importações de soja, principalmente argentina e paraguaia, por parte de grandes lideres do mercado, como a CARGILL.

Devido à disputa nacional pela matéria-prima espera-se que os contratos de fornecimento da soja em grão tendam a aumentar. Segundo SCHOUCHANA (s.d. "an) o mecanismo soja verde foi muito utilizado nos anos 1990-93. Na safra 1993/94 este mecanismo foi responsável por quase um terço da comercialização total de soja no pais, mas apresentou sérios problemas de inadimplência (não entrega da produção efetivamente negociada), o que acabou reduzindo sua participação no total comercializado, na safra 1994/95, para menos de 10\%. Já o número de negociações com CPR e CM-G cresceu significativamente devido às maiores garantias de entrega da mercadoria (CANZIANI, 1995).

\subsubsection{Simulações}

Para comparar qual seria o custo financeiro para o produtor de acordo com a opção feita para a obtenção dos recursos de financiamento para o custeio da produção - CMFG, CPR ou contrato tradicional através do SNCR, foram simulados contratos equivalentes tomando como base os dados reais ${ }^{46}$ contidos nas cédulas rurais pignoraticias, relativos a três diferentes operações de custeio de soja não irrigada, localizadas na região de Assis, São Paulo, para as safras $94 / 95,95 / 96$ e 96/97. Nas Tabelas 15, 16 e 17 são apresentadas de forma detalhada cada uma das operações utilizadas como referência para as simulações.

4. Os dados básicos utilizados, referentes às operações em questão, constam da Cédula Rural Pignoratícia e da Conta Gráfica correspondente e foram fornecidos pelos técnicos do Banco do Brasil em São Paulo, tendo sido omilidos por eles, todos os dados sigilosos. 
Tabela 15 - Descrição da operação 1: custeio de soja não irrigada, região de Assis, safra 1994/95

\begin{tabular}{|c|c|c|c|}
\hline Item & Caracteristica & Observações & Dados \\
\hline 1 & produto & soja não irrigada & - \\
\hline 2 & região de produção & Assis - São Paulo & - \\
\hline 3 & safra (periodo agricola) & $1994 / 95$ & - \\
\hline \multirow[t]{2}{*}{4} & periodo do contrato & inicio & $24 / 10 / 1994$ \\
\hline & & vencimento/liquidação & $14 / 03 / 1995$ \\
\hline 5 & área plantada (ha) & - & 48,00 \\
\hline 6 & produção esperada $(\mathrm{kg})$ & - & $130.680,00$ \\
\hline 7 & produtividade $(\mathrm{kg} / \mathrm{ha})$ & - & $2.722,50$ \\
\hline \multirow[t]{3}{*}{8} & volume de recursos & total $(A+P)$ & $R \$ 10.893,96$ \\
\hline & & crédito $(\mathrm{A})$ & $R \$ 6.621,82$ \\
\hline & & recursos próprios $(P)$ & $\mathrm{R} \$ 4.272,14$ \\
\hline \multirow[t]{3}{*}{9} & crédito (A) & $24 / 10 / 1994$ & $\mathrm{R} \$ 5.423,64$ \\
\hline & & $01 / 11 / 1994$ & $R \$ 590,09$ \\
\hline & & $01 / 03 / 1995$ & $R \$ \quad 608,09$ \\
\hline \multirow[t]{3}{*}{10} & recursos próprios $(\mathrm{P})$ & $24 / 10 / 1994$ & $R \$ 3.499,12$ \\
\hline & & $01 / 11 / 1994$ & $\mathrm{R} \$ \quad 380,70$ \\
\hline & & $01 / 03 / 1995$ & $\mathrm{R} \$ \quad 392,32$ \\
\hline 11 & encargos financeiros ${ }^{1}$ & - & TR. $+11 \%$ efetivo aa \\
\hline \multirow[t]{4}{*}{12} & saldo liquidado & total $(A+B+C)$ & $R \$ 7.767,60$ \\
\hline & & crédito $(\mathrm{A})$ & $R \$ 6.621,82$ \\
\hline & & juros (B) & $R \$ 313,04$ \\
\hline & & correção (C) & $\mathrm{R} \$ \quad 832,74$ \\
\hline 13 & receita esperada total ${ }^{2}$ & - & $\mathrm{R} \$ 17.728,92$ \\
\hline
\end{tabular}

Fonte: Os dados básicos utilizados constam da Cédula Rural Pignoraticia e da Conta Gráfica correspondente $\theta$ foram fornecidos pelos técnicos do Banco do Brasil em São Paulo (foram omitidos todos os dados sigilosos).

${ }^{1}$ Sobre os valores lançados e o saldo devedor incidem encargos ao mês calculados com base na taxa referencial (TR). Sobre o valor resultante, incidem juros a taxa nominal de $10,482 \%$ ao ano (método hamburguês $/ 360$ dias), correspondendo a $11 \%$ efetivos ao ano. Os encargos citados são debitados e capitalizados mensalmente.

${ }^{2}$ Calculada com base no preço mínimo vigente na data da contratação $(R \$ 8,14)$. 
Tabela 16 - Descrição da operação 2: custeio de soja não irrigada, região de Assis, safra 1995/96

\begin{tabular}{|c|c|c|c|}
\hline Item & Caracteristica & Observações & Dados \\
\hline 1 & produto & soja não irrigada & - \\
\hline 2 & região de produção & Assis - São Paulo & - \\
\hline 3 & safra (periodo agricola) & $1995 / 96$ & - \\
\hline \multirow[t]{2}{*}{4} & periodo do contrato & inicio & $19 / 09 / 1995$ \\
\hline & & vencimento/iquidaçāo & $20 / 03 / 1996$ \\
\hline 5 & área plantada (ha) & - & 144,00 \\
\hline 6 & produção esperada (kg) & - & $214.200,00$ \\
\hline 7 & produtividade (kg/ha) & - & $1.487,50$ \\
\hline \multirow[t]{3}{*}{8} & volume de recursos & total $(A+P)$ & $R \$ 14.610,96$ \\
\hline & & crédito (A) & $R \$ 11.688,77$ \\
\hline & & recursos próprios $(\mathrm{P})$ & $\mathrm{R} \$ 2.922,19$ \\
\hline \multirow[t]{3}{*}{9} & crédito $(A)$ & $19 / 09 / 1995$ & $R \$ 8.220,68$ \\
\hline & & $01 / 11 / 1995$ & $R \$ 2.533,82$ \\
\hline & & $01 / 02 / 1996$ & $R \$ 934,27$ \\
\hline \multirow[t]{3}{*}{10} & recursos próprios $(\mathrm{P})$ & $19 / 09 / 1995$ & $\mathrm{R} \$ 2.055,17$ \\
\hline & & $01 / 11 / 1995$ & $R \$ \quad 633,45$ \\
\hline & & $01 / 02 / 1996$ & $R \$ \quad 233,57$ \\
\hline 11 & encargos financeiros ${ }^{1}$ & - & $16 \%$ efetivo aa \\
\hline \multirow[t]{4}{*}{12} & saldo liquidado & total $(A+B+C)$ & $R \$ 12.507,26$ \\
\hline & & crédito $(A)$ & $R \$ 11.688,77$ \\
\hline & & juros $(B)$ & $\mathrm{R} \$ \quad 818,49$ \\
\hline & & correção $(C)$ & - \\
\hline 13 & receita esperada total ${ }^{2}$ & - & $R \$ 29.059,80$ \\
\hline
\end{tabular}

Fonte: Os dados básicos utilizados constam da Cédula Rural Pignoraticia e da Conta Gráfica correspondente e foram fornecidos pelos técnicos do Banco do Brasil em São Paulo fforam omitidos todos os dados sigilosos).

${ }^{1}$ Sobre os valores lançados e o saldo devedor incidem juros a taxa nominal de $14,934 \%$ ao ano/método hamburguês/360 dias), correspondendo a $16 \%$ efetivos ao ano. Os encargos citados são debitados e capitalizados mensalmente.

${ }^{2}$ Calculada com base no preço minimo vigente na data da contratação $(R \$ 8,14)$. 
Tabela 17 -Descrição da operação 3: custeio de soja não irrigada, região de Assis, safra 1996/97

\begin{tabular}{|c|c|c|c|}
\hline Item & Caracteristica & Observaçōes & Dados \\
\hline 1 & produto & soja não imigada & - \\
\hline 2 & região de produção & Assis - São Paulo & - \\
\hline 3 & safra (periodo agricola) & $1996 / 97$ & - \\
\hline \multirow[t]{2}{*}{4} & periodo do contrato & inicio & $18 / 09 / 1996$ \\
\hline & & vencimento/liquidação & $20 / 03 / 1997$ \\
\hline 5 & área plantada (ha) & - & 53,20 \\
\hline 6 & produção esperada $(\mathrm{kg})$ & - & $117.040,00$ \\
\hline 7 & produtividade (kg/ha) & - & $2.200,00$ \\
\hline \multirow[t]{3}{*}{8} & volume de recursos & total $(A+P)$ & $R \$ 12.115,83$ \\
\hline & & crédito (A) & $R \$ 9.692,66$ \\
\hline & & recursos próprios $(P)$ & $R \$ 2.423,17$ \\
\hline 9 & crédito $(A)$ & $18 / 09 / 1996$ & $\mathrm{R} \$ 9.692,66$ \\
\hline 10 & recursos próprios $(\mathrm{P})$ & $18 / 09 / 1996$ & $\mathrm{R} \$ 2.423,17$ \\
\hline 11 & encargos financeiros ${ }^{1}$ & - & $12 \%$ efetivo aa \\
\hline \multirow[t]{4}{*}{12} & saldo liquidado & total $(A+B+C)$ & $R \$ 10.270,12$ \\
\hline & & crédito (A) & $R \$ 9.692,66$ \\
\hline & & juros (B) & $\mathrm{R} \$ 577,46$ \\
\hline & & correção (C) & - \\
\hline 13 & receita esperada total ${ }^{2}$ & - & $17.321,92$ \\
\hline
\end{tabular}

Fonte: Os dados básicos utilizados constam da Cédula Rural Pignoraticia e da Conta Gráfica correspondente e foram fomecidos pelos técnicos do Banco do Brasil em São Paulo (foram omitidos todos os dados sigilosos).

${ }^{1}$ Sobre os valores lançados e o saldo devedor incidem juros a taxa nominal de $10,482 \%$ ao ano (método hamburguês $/ 360$ dias), correspondendo a $11 \%$ efetivos ao ano. Os encargos citados são debitados e capitalizados mensalmente.

${ }^{2}$ Calculada com base no preço minimo vigente na data da contratação $(R \$ 8,88)$. 
A partir das informaçõeș anteriores foram simuladas as operações com a CPR e 0 CMFG. Como estes titulos antecipam recursos, em primeiro lugar obteve-se o preço provável de negociação desses títulos a partir das cotações no mercado futuro. Foram utilizadas as cotações da Bolsa de Mercadorias de Chicago (CBOT) que constam do apêndice 1. Como o pico de safra da soja no Brasil se dá entre março e maio, tomou-se como referência a cotação futura destes meses, de forma a verificar em que mês seria mais interessante para o produtor o vencimento do contrato.

Na decomposição do preço futuro CBOT para o mercado interno considerou-se o porto de Paranaguá, local de escoamento para a produção de Assis, São Paulo. Como resultado, foi obtido o preço futuro FOB/Paranaguá (PFOBPAR) ${ }^{47}$. O resultado obtido em dólares foi transformado para reais utilizando-se a cotação do dia da operação que consta do apêndice 2.

No entanto, como o preço FOB/Paranaguá (PFOBPAR) também é um preço futuro, utilizando a metodologia apresentada no capitulo 1 , foi desenvolvida a decomposição deste preço para o valor líquido indicativo da CPR (VliqCPR) e do CMFG (VliqCMFG) passando por estabelecer o valor de negociação $(\mathrm{Vn})$ da CPR e do CMFG.

Na Tabela 18 apresentada a seguir, constam para as três operações, os valores da saca de soja em todas as fases de decomposição, bem como o custo de produção.

4 A descrição detalhada para cada uma das operações pode ser verificado nos apêndices 3,4 e 5 . 
Tabela 18 - Preço futuro da soja na Bolsa de Chicago (CBOT) decomposto para pagamento antecipado através da CPR e do CMFG

\begin{tabular}{|c|c|c|c|c|c|c|c|c|c|c|c|c|}
\hline Operação & $\begin{array}{c}\text { Data de lib. } \\
\text { dos rec. }\end{array}$ & $\begin{array}{r}\text { PFC } \\
\text { Preço fu } \\
\text { (na data de } \\
\text { (R\$ }\end{array}$ & $\begin{array}{l}\text { BOT } \\
\text { t. CBOT } \\
\text { lib. dos rec.) } \\
\text { /sc) }\end{array}$ & $\begin{array}{r}\text { PFO } \\
\text { Preço fut.FO } \\
\text { (na data de } \\
(\mathrm{R} \$\end{array}$ & $\begin{array}{l}\text { BPAR } \\
\text { B/Paranaguá } \\
\text { lib. dos rec.) } \\
\$(\mathrm{sc})\end{array}$ & $\begin{array}{r}V r \\
\text { á Valor de ne } \\
\text { CPR ed } \\
(\mathrm{R} \$ \\
\end{array}$ & $\begin{array}{l}\text { gociação da } \\
\text { o CMFG } \\
\text { (sc) } \\
\end{array}$ & Vliq & CPR & VliqCl & MFG & $\begin{array}{c}\text { Custo de } \\
\text { produção } \\
\text { (R\$/sc) }\end{array}$ \\
\hline $\begin{array}{c}1 \\
\text { out/94 }\end{array}$ & & (março/95) & (maio/95) & (março/95) & (maio/95) & (março/95) & (maio/95) & (março/95) & (maio/95) & (março/95) & (maio/95) & \\
\hline mar/95 & $24 / 10 / 94$ & 11,13 & 11,14 & 8,28 & 8,30 & 7,23 & 6,82 & 6,95 & 6,47 & 6,98 & 6,52 & 6,31 \\
\hline ou & $01 / 11 / 94$ & 10,86 & 10,90 & 8,06 & $8 ; 10$ & 7,05 & 6,66 & 6,82 & 6,36 & 6,82 & 6,38 & 6,47 \\
\hline mai/95 & 01/03/95 & 10,77 & 10,86 & 7,98 & 8,06 & 7,90 & 7,61 & 7,82 & 7,46 & 7,80 & 7,43 & 6,79 \\
\hline $\begin{array}{c}2 \\
\text { set/95 }\end{array}$ & & (março/96) & (maio/96) & (março/96) & (maio/96) & (março/96) & (maio/96) & (março/96) & (maio/96) & (março/96) & (maio/96) & \\
\hline $\operatorname{mar} / 96$ & 19/09/95 & 14,48 & 14,49 & 10,91 & 10,92 & 9,04 & 8,50 & 8,64 & 8,01 & 8,68 & 8,07 & 8,00 \\
\hline ou & $01 / 11 / 95$ & 15,18 & 15,18 & 11,49 & 11,49 & 10,40 & 9,95 & 10,07 & 9,50 & 10,05 & 9,52 & 8,13 \\
\hline $\mathrm{mai} / 96$ & $01 / 02 / 96$ & 16,53 & 16,52 & 12,63 & 12,62 & 12,28 & 11,85 & 12,15 & 11,62 & 12,06 & 11,51 & 8,36 \\
\hline $\begin{array}{c}3 \\
\text { set/96 }\end{array}$ & & (março/97) & (maio/97) & (março/97) & (maio/97) & (março/97) & (maio/97) & (março/97) & (maio/97) & (março/97) & (maio/97) & \\
\hline $\begin{array}{c}\text { mar/97 } \\
\text { ou mai/97 }\end{array}$ & $18 / 09 / 96$ & 17,92 & 17,86 & 13,76 & 13,70 & 12,85 & 12,50 & 12,27 & 11,78 & 12,30 & 11,97 & 8,30 \\
\hline
\end{tabular}


Observa-se que em cada uma das operações o valor liquido obtido difere dependendo da data de negociação, confirmando a possibilidade de operações mais ou menos vantajosas para o produtor na obtenção dos recursos, avaliada com relação ao custo de produção.

Nas três operações consideradas, a opção de entrega do produto em março resultaria em maior lucro para o produtor, visto que os preços estimados para este mês, pico da colheita, mostraram-se superiores aos de maio e acima dos custos de produção.

A opção pela entrega em maio, mostra-se menos vantajosa, pois além dos valores líquidos obtidos serem menores, haveria um custo adicional de armazenagem pelo período aproximado de dois meses, reduzindo a margem e, portanto, a renda do produtor. Nas safras 95/96 e 96/97 as margens de lucro mostram-se mais elevadas que na safra anterior, refletindo uma elevação nos preços cotados para o produto, proporcionalmente maior que a variação de custo de produção.

Os valores obtidos através das negociações com CPR e CMFG, em geral, foram muito próximas, não havendo diferenças significativas no tocante à cobertura dos custos de produção.

A partir dos resultados obtidos anteriormente (PFOBPAR e o VliqCPR e VliqCMFG) e utilizando as equações (9) e (10) foi possivel calcular qual a taxa de desconto efetiva embutida nas negociações com CPR e CMFG, no caso destas simulações. Estas taxas são apresentadas nas Tabelas 19 e 20. 
Tabela 19 - Taxa de desconto na decomposição do preço futuro da soja FOB/Paranaguá (PFOBPAR) para valor líquido da CPR(VliqCPR).

\begin{tabular}{|c|c|c|c|c|c|c|c|c|c|c|c|c|c|}
\hline $\begin{array}{c}\mathrm{N}^{\circ} \mathrm{da} \\
\text { operação } \\
\text { (inic/venc) }\end{array}$ & $\begin{array}{l}\text { Data de } \\
\text { lib. dos } \\
\text { recursos }\end{array}$ & \multicolumn{2}{|c|}{$\begin{array}{c}\mathrm{N} \\
\mathrm{N}^{0} \text { de dias } \\
\text { (inicio/venc.) }\end{array}$} & \multicolumn{2}{|c|}{$\begin{array}{c}\text { PFOBPAR } \\
\text { Preço fut. } \\
\text { (na data de lib dos rec) } \\
\text { (R } \$ / \mathrm{sc})\end{array}$} & \multicolumn{2}{|c|}{ VliqCPR } & \multicolumn{2}{|c|}{$\begin{array}{c}\text { Taxa de desc. } \\
\text { no periodo } \\
(\%) \\
\end{array}$} & \multicolumn{2}{|c|}{$\begin{array}{c}\text { Taxa de desc. } \\
\text { ao mês } \\
(\%)\end{array}$} & \multicolumn{2}{|c|}{$\begin{array}{c}\text { Taxa de desc. } \\
\text { ao ano } \\
(\%) \\
\end{array}$} \\
\hline 1 & & (março/95) & (maio/95) & (março/95) & (maio/95) & (maço/95) & (maio/95) & (março/95) & (maio/95) & (março/95) & (maio/95) & (março/95) & (maio/95) \\
\hline \multicolumn{14}{|l|}{ out/94 } \\
\hline $\operatorname{mar} / 95$ & $24 / 10 / 94$ & 141 & 202 & 8,28 & 8,30 & 6,95 & 6,47 & $\cdot 19,24$ & 28,24 & 3,81 & 3,76 & 56,71 & 55,78 \\
\hline ou & $01 / 11 / 94$ & 133 & 194 & 8,06 & 8,10 & 6,82 & 6,36 & 18,11 & 27,31 & 3,83 & 3,80 & 56,93 & 56,52 \\
\hline mail95 & $01 / 03 / 95$ & 13 & 74 & 7,98 & 8,06 & 7,82 & 7,46 & 2,09 & 8,03 & 4,89 & 3,18 & 77,27 & 45,64 \\
\hline 2 & & (março/95) & (maio/95) & (março/96) & (maio/96) & (maço/96) & (maio/96) & (março/96) & (maio/96) & (março/96) & (maio/96) & (março/96) & (maio/96) \\
\hline \multicolumn{14}{|l|}{ set/95 } \\
\hline mar/96 & $19 / 09 / 95$ & 183 & 244 & 10,91 & 10,92 & 8,64 & 8,01 & 26,28 & 36,27 & 3,90 & 3,88 & 58,24 & 57,86 \\
\hline ou & $01 / 11 / 95$ & 140 & 201 & 11,49 & 11,49 & 10,07 & 9,50 & 14,15 & 20,85 & 2,88 & 2,87 & 40,54 & 40,38 \\
\hline $\mathrm{mai} / 96$ & $01 / 02 / 96$ & 48 & 109 & 12,63 & 12,62 & 12,15 & 11,62 & 3,92 & 8,66 & 2,43 & 2,31 & 33,43 & 31,56 \\
\hline 3 & & (março/95) & (maio/95) & (março/97) & (maio/97) & (maço/97) & (maio/97) & (março/97) & (maio/97) & (março/97) & (maio/97) & (março/97) & (maio/97) \\
\hline \multicolumn{14}{|l|}{ set/96 } \\
\hline $\mathrm{mar} / 97$ & $18 / 09 / 96$ & 183 & 244 & 13,76 & 13,70 & 12,27 & 11,78 & 12,15 & 16,32 & 1,90 & 1,88 & 25,29 & 24,99 \\
\hline \multicolumn{14}{|l|}{ ou } \\
\hline $\mathrm{mai} / 97$ & & & & & & & & & & & & & \\
\hline
\end{tabular}

Fonte: Dados da pesquisa (Apêndices 6 e 7 ) 
Tabela 20 - Taxa de desconto na decomposição do preço futuro da soja FOB/Paranaguá (PFOBPAR) para valor líquido do CMFG (NiqCMFG)

\begin{tabular}{|c|c|c|c|c|c|c|c|c|c|c|c|c|c|}
\hline \multirow{2}{*}{$\begin{array}{c}N^{\circ} \text { da } \\
\text { operação } \\
\text { (inic/venc) }\end{array}$} & $\begin{array}{l}\text { Data de } \\
\text { lib. dos } \\
\text { recursos }\end{array}$ & \multicolumn{2}{|c|}{$\begin{array}{c}\mathrm{N} \\
\mathrm{N}^{0} \text { de dias } \\
\text { (inicio/venc.) }\end{array}$} & \multicolumn{2}{|c|}{$\begin{array}{c}\text { PFOBPAR } \\
\text { Preço fut. } \\
\text { (na data de lib dos rec) } \\
(\mathrm{R} \$ / \mathrm{sc}) \\
\end{array}$} & \multicolumn{2}{|c|}{ VliqCMFG } & \multicolumn{2}{|c|}{$\begin{array}{c}\text { Taxa de desc. } \\
\text { no periodo } \\
(\%)\end{array}$} & \multicolumn{2}{|c|}{$\begin{array}{c}\text { Taxa de desc. } \\
\text { ao mês } \\
(\%)\end{array}$} & \multicolumn{2}{|c|}{$\begin{array}{c}\text { Taxa de desc. } \\
\text { ao ano } \\
(\%)\end{array}$} \\
\hline & & (março/95) & (maio/95) & (março/95) & (maio/95) & (marso/95) & (maio/95) & (março/95) & (maio/95) & (março/95) & (maio/95) & (março/95) & (maio/95) \\
\hline out/94 & & & & & & & & & & & & & \\
\hline $\operatorname{mar} / 95$ & $24 / 10 / 94$ & 141 & 202 & 8,28 & 8,30 & 6,98 & 6,52 & 18,63 & 27,20 & 3,70 & 3,64 & 54,69 & 53,53 \\
\hline ou & $01 / 11 / 94$ & 133 & 194 & 8,06 & 8,10 & 6,82 & 6,38 & 18,15 & 26,96 & 3,83 & 3,76 & 57,04 & 55,74 \\
\hline mai/95 & $01 / 03 / 95$ & 13 & 74 & 7,98 & 8,06 & 7,80 & 7,43 & 2,31 & 8,37 & 5,40 & 3,31 & 88,04 & 47,87 \\
\hline 2 & & (março/95) & (maio/95) & (março/95) & (maio/95) & (março/95) & (maio/95) & (março/95) & (maio/95) & (março/95) & (maio/95) & (março/95) & (maio/95) \\
\hline set/95 & & & & & & & & & & & & & \\
\hline mar/96 & $19 / 09 / 95$ & 183 & 244 & 10,91 & 10,92 & 8,68 & 8,07 & 25,69 & 35,23 & 3,82 & 3,78 & 56,81 & 56,09 \\
\hline ou & $01 / 11 / 95$ & 140 & 201 & 11,49 & 11,49 & 10,05 & 9,52 & 14,32 & 20,67 & 2,91 & 2,84 & 41,07 & 40,00 \\
\hline mail96 & $01 / 02 / 96$ & 48 & 109 & 12,63 & 12,62 & 12,06 & 11,51 & 4,75 & 9,64 & 2,94 & 2,57 & 41,59 & 35,53 \\
\hline $\begin{array}{c}3 \\
\text { set/96 }\end{array}$ & & (março/95) & (maio/95) & (março/95) & (maio/95) & (março/95) & (maio/95) & (março/95) & (maio/95) & (março/95) & (maio/95) & (março/95) & (maio/95) \\
\hline $\begin{array}{c}\mathrm{mar} / 97 \\
\text { ou } \\
\mathrm{ma} / 97\end{array}$ & $18 / 09 / 96$ & 183 & 244 & 13,76 & 13,70 & 12,30 & 11,97 & 11,91 & 14,50 & 1,86 & 1,68 & 24,78 & 22,11 \\
\hline
\end{tabular}


As taxas anuais embutidas na formação de preços, tanto no caso da CPR como do CMFG, variaram de aproximadamente $55 \%$ ao ano no primeiro periodo, $1994 / 95$, a $25 \%$ ao ano na safra 1996/97. O custo de oportunidade do capital foi o fator de maior peso, refletindo as elevadas taxas de juros após a implantação do Plano Real.

Na operação 1, safra 1994/95, observou-se taxas de desconto excessivamente elevadas de $77,27 \%$ ao ano e $88,04 \%$ ao ano, respectivamente para a CPR e o CMFG. Acredita-se que estas estejam refletindo a incidência de taxas não proporcionais ao tempo, tais como as de registro e operação em bolsa.

O problema da não proporcionalidade das taxas com relação ao tempo se repete na sistemática de cobrança do aval no caso da emissão da CPR, e do seguro garantia de obrigações contratuais no caso do CMFG.

Desta forma, constata-se que para periodos muito pequenos os custos fixos por operação tornam-se muito onerosos. Em periodos mais longos este custo tende a se diluir. Portanto, 0 fator tempo ou seja, duração do contrato, deve ser levado em consideração quando da contratação destas operações

Os custos envolvidos na emissão dos titulos (taxas de descontos ao ano), foram em média 30 pontos percentuais menores na safra $96 / 97$ com relação às duas safras anteriores. Interessante notar que em matéria da Agrofolha em 02/10/96 são citados juros de $24 \%$ ao ano para CPR referentes a safra 96/97, praticamente a mesma taxa encontrada no caso da simulação com a operação 3 , de $25,29 \%$ ao ano para entrega em março e $24,99 \%$ ao ano para entrega em maio. No caso do CMFG, as taxas obtidas foram menores, $24,78 \%$ ao ano e $22,11 \%$ ao ano respectivamente, em função da utilização do Seguro Garantia de Obrigações Contratuais que representou um custo sobre o valor de negociação de $3,25 \%$, em contraposição ao custo do aval na CPR de $3,9 \%$, para março e de $5,2 \%$ para maio. 
Se os preços são sistematicamente maiores para entrega em março, com diferenças em torno de $4 \%$ a $7 \%$ com relação ao preço para entrega em maio, o mesmo não se verifica com as taxas de desconto ao ano que não variam significativamente, levando a conclusão que os contratos, pelo menos nesse periodo analisado, deveriam ser negociados para entrega em março, 0 que resultaria numa receita liquida maior para o produtor além de não envolver custos com armazenamento.

A opção entre utilizar a CPR ou o CMFG para alavancagem de recursos passa a ser mais interessante em termos de aumento da receita liquida a partir da safra 1996/97, fato diretamente relacionado a utilização, no CMFG, do Seguro Garantia de Obrigações Contratuais para garantia da entrega efetiva da mercadoria. Para periodos de cinco meses o custo do aval prestado pelo Banco do Brasil à taxa definida para início de plantio ( $0,65 \%$ ao mês) e o custo do seguro garantia de obrigações contratuais se equivalem. Para periodos maiores, a opção pelo CMFG, garantido por seguro garantia, será tanto mais interessante quanto maior for o periodo em questão, pois é dado por uma taxa fixa ao ano.

Se adicionalmente forem considerados os custos de registro em bolsa, sob a hipótese de que o produtor (emitente) arca com a totalidade dos custos de negociação - no caso do CMFG de $0,525 \%$ do valor do certificado para cada parte, somando $1,05 \%$, e de $0,60 \%$ no caso da $\mathrm{CPR}$, ambas sobre o valor de negociação do contrato - a utilização do CMFG seria mais rentável para o produtor a partir de periodos maiores que 6 meses.

Uma forma alternativa para comparar os contratos estabelecidos pelo produtor através do CMFG, da CPR e do SNCR é sob o ângulo da obtenção de recursos com base em equivalente produto. Na Tabela 21 são apresentados os resultados obtidos com base nas equações (11), (12) e (13) para os três tipos de contratos citados, que equivalem ao número de sacas necessárias para pagar o financiamento, de acordo com a utilização da CPR, CMFG ou SNCR para captação dos recursos para o custeio da produção. 
Tabela 21 - Equivalente sacas dos recursos necessários para custeio de soja de acordo com os contratos CPR, CMFG e SNCR e variação com relação ao $E_{S N C R}$

\begin{tabular}{ccrrrrr}
\hline \multirow{2}{*}{$\begin{array}{c}N^{0} \text { da } \\
\text { operação }\end{array}$} & Safra & \multicolumn{5}{c}{ Número de sacas equivalentes e variação com relação ao $E_{\text {SNCR }}$} \\
\cline { 3 - 7 } & & \multicolumn{2}{c}{$E_{\text {CPR }}$} & \multicolumn{2}{c}{$E_{\text {CMFG }}$} & \multicolumn{1}{c}{$E_{\text {SNCR }}$} \\
\cline { 3 - 7 } & & $N^{0}$ & $\%$ & $N^{0}$ & $\%$ & \multicolumn{1}{c}{$N^{\circ}$} \\
\hline 1 & $1994 / 95$ & 944,66 & 0,7 & 941,51 & 0,4 & 938,12 \\
2 & $1995 / 96$ & $1.279,98$ & 11,6 & $1.276,67$ & 11,4 & $1.146,40$ \\
3 & $1996 / 97$ & 789,95 & 5,8 & 788,02 & 5,6 & 746,38 \\
\hline
\end{tabular}

Fonte: Elaborado com base nos Apêndices 9 e 10.

Nas três operações o número de sacas comprometidas para pagar o financiamento foi maior no caso da CPR, e menor no caso do SNCR. Enquanto na safra 1994/95 a diferença, em termos do número de sacas comprometidas, entre o CMFG e o SNCR ficou em torno de 0,4\%, na safra seguinte a diferença subiu para $11,4 \%$ e, na safra $1996 / 97$, caiu para $5,6 \%$. É interessante notar que a CPR manteve-se muito próximo do CMFG em número de sacas por parcela/contrato, variando com relação ao SNCR, respectivamente, nas três safras consideradas, em $0,7 \%, 11,6 \%$ e $5,8 \%$.

O resultado na safra 94/95 deveu-se, principalmente, a cobrança da TR, além da taxa de juros de $11 \%$ cobradas no financiamento pelas regras do SNCR naquela safra. Nas operações 2 e 3, devido a incidência apenas da taxa de juros, respectivamente de $16 \%$ e $12 \%$ ao ano, o contrato tradicional continuou a ser a melhor opção. No entanto, como a política de crédito rural tem priorizado o financiamento de produtos da cesta básica, e os recursos são escassos, apenas pequenos produtores são atendidos no caso da produção de soja.

Além disso, os preços tiveram uma alta expressiva entre o plantio e a colheita, demonstrando um comportamento inverso ao esperado, de maiores preços próximo a safra, beneficiando o produtor que deixou para vender sua safra após a colheita, caso do produtor que utilizou o SNCR. Aquele que vendeu anteçipadamente não absorveu essa alta, comprometendo, consequentemente, mais sacas no financiamento. 
A partir das simulações efetuadas neste estudo pode-se concluir que as operações com a CPR e o CMFG trariam resultados de receitas semelhantes para o produtor, envolvendo taxas de descontos bastante elevadas. Por outro lado, os recursos obtidos através do SNCR, são os que permitiram o menor custo financeiro no custeio da safra, resultando em maior receita. Porém, esses recursos são limitados. Tolhida por recursos escassos, a agricultura abre espaço para novas formas de financiamento através do mercado de titulos.

Os resultados obtidos podem incorrer em alguma variação, subestimando ou superestimando valores. No entanto, para o objetivo proposto, esse fato é pouco relevante para a comparação dos titulos, pois a maioria das informações utilizadas são as mesmas nos dois casos, como: custo do frete, taxa de câmbio, impostos, taxas de corretagem, etc.

Fato que efetivamente pode alterar os resultados é a capacidade de negociação e as condições em que são feitos os negócios. Apenas nas entrevistas com os vários seguimentos envolvidos com a negociação desses títulos pode-se constatar que praticamente tudo é negociável e, basicamente, dependem da ficha cadastral dos clientes e das garantias aportadas. Dessa forma, praticamente cada operação torna-se única.

Apesar das altas taxas de descontos presentes nas negociações com os titulos aqui analisados, o crescimento das operações com a CPR e CMFG, observadas nas Tabelas 11,12 e 13 já apresentadas, demonstram que há produtores interessados. A explicação está principalmente em três fatores: bons preços no mercado internacional, falta de recursos próprios e praticamente nenhuma disponibilidade de recursos governamentais. 


\section{CONCLUSÕES}

O Certificado de Mercadoria com Emissão Garantida, CM-G, é um titulo representativo de mercadoria cuja natureza jurídica é a de um contrato mercantil de compra e venda de mercadoria. Voltado especificamente para o mercado fisico, constitui-se num avanço às modalidades de negociação existentes, pois compõe um sistema onde os riscos tão comuns às operações nesse mercado são reduzidos.

Esse sistema de negociação envolve muito mais do que as partes compradora e vendedora e os corretores, tendo sido concebido para fazer interagir, cada um com sua função, os vários setores que atuam nesse sistema de comercialização de produtos agricolas. São eles, além dos já citados, o banco e/ou a seguradora, que garantem o cumprimento do contrato, os armazenadores, as bolsas de mercadorias e a Câmara de compensação de Negócios.

O elo de ligação entre os agentes é a Câmara de compensação de Negócios, cujo objetivo social é o registro, a compensação, a administração das garantias e a liquidação dos negócios. No cumprimento desses objetivos, torna-se o principal agente garantidor do sistema e, conseqüentemente, o principal responsável pela redução do risco de inadimplência, de ambas as partes, nas negociações do mercado físico através do $\mathrm{CM}-\mathrm{G}$.

$O$ aumento de credibilidade conferido por esse sistema operacional ao mercado fisico, cria condições para o seu desenvolvimento ao estimular os produtores rurais e cooperativas a comercializar sua produção, através de bolsa, diretamente com o mercado consumidor, exportador e industrial. Este sistema, que tem como característica ser livre, regularizado e transparente, incentiva 0 fortalecimento da iniciativa privada e cria condições favoráveis à sua auto-regulação. 
O fortalecimento do mercado físico, através do aumento de credibilidade e crescimento das operações em bolsa, tem efeito multiplicador para os negócios agricolas em geral, na medida em que abre espaço para o crescimento do mercado secundário de títulos, tornando o setor capaz de se auto-financiar, bem como dá respaldo às operações no mercado de futuros, contribuindo para o seu crescimento e desenvolvimento.

Considera-se que o $\mathrm{CM}-\mathrm{G}$, do lado do produtor, ao permitir a fixação do preço de venda da mercadoria, e garantir a entrega fisica do produto, reduza a incerteza e o risco de diminuição da renda. Do lado do comprador, espera-se que a utilização dos CM-G reduza a incerteza com relação a disponibilidade do produto no momento necessário, bem como o risco de ter que arcar com fortes oscilações de preços, permitindo um melhor planejamento do processo de produção da empresa, principalmente se associado a mecanismos de hedge em Bolsa de futuros. Havendo uma redução do risco nas duas pontas, pressupõe-se que ocorrerá, como conseqüência, uma maior estabilidade do mercado de produtos agricolas.

O presente estudo teve por objetivo descrever e analisar o Certificado de Mercadoria com Emissão Garantida (CM-G), com ênfase na modalidade para entrega futura (CMFG), bem como a estrutura que the dá suporte. Tal ênfase se deveu ao fato de que $99 \%$ das negociaçōes com o CM-G, as quais atingiram o volume de US $\$ 4,8$ bihões no ano de 1995 , foram realizadas na modalidade CMFG.

Pretendeu-se mostrar qual o papel que a bolsa de mercadorias e cereais, a clearing house, 0 sistema de seguros e a armazenagem desempenham na viabilização do certificado, constituindo 0 sistema de negociação do CM-G.

Efetuou-se também a análise comparativa das características do CM-G com relação à Cédula de Produto Rural (CPR), titulo que também se propõe à comercialização antecipada do produtos agricolas para alavancagem de capital. Diante da caracteristica de incerteza do processo de produção agricola e da importância que os custos financeiros envolvidos na obtenção de recursos para financiamento representam para o empreendimento rural, procurou-se determinar comparativamente, através de simulações, qual o custo financeiro envolvido na utilização do $C M-G$, da CPR e dos contratos 
tradicionais de crédito, baseados nas normas do Sistema Nacional de Crédito Rural (SNCR) para o custeio de soja, nas safras 94/95, 95/96 e 96/97.

A partir das simulações efetuadas neste estudo pode-se concluir que as operações com a CPR e o CMFG trariam resultados de receitas semelhantes para o produtor, envolvendo taxas de descontos bastante elevadas. Por outro lado, os recursos obtidos através do SNCR são os que permitiram o menor custo financeiro no custeio da safra e, portanto, a maior receita, mesmo na safra 1994/95, quando ainda eram comigidos pela TR mais juros. No entanto, atende apenas aos pequenos produtores pois, o limite de crédito para a cultura da soja foi estabelecido em $R \$ 30.000,00$ (safra 1996/97).

Este fato reflete as mudanças na orientação da politica de financiamento da agricultura que, tolhida por recursos escassos, abre espaço para novas formas de financiamento da agricultura através do mercado de titulos.

As taxas anuais embutidas na formação de preços, tanto no caso da CPR como do CMFG, variaram de aproximadamente $55 \%$ ao ano no primeiro periodo, $1994 / 95$, a $25 \%$ na safra 1996/97. O custo de oportunidade do capital foi o fator de maior peso, refletindo as elevadas taxas de juros após a implantação do Plano Real.

A opção entre utilizar a CPR ou o CMFG para alavancagem de recursos passa a ser mais interessante em termos de aumento da receita líquida a partir da safra 1996/97, fato diretamente relacionado à utilização, no CMFG, do Seguro Garantia de Obrigações Contratuais (Seguro GOC) para garantia da entrega efetiva da mercadoria. Para periodos de cinco meses o custo do aval prestado pelo Banco do Brasil à taxa definida para inicio de plantio $(0,65 \%$ ao mês) e o custo do Seguro GOC se equivalem. Para períodos maiores, a opção pelo CMFG, garantido por seguro garantia, será tanto mais interessante quanto maior for o periodo em questão, pois é dado por uma taxa fixa ao ano. 
Nas entrevistas com os vários seguimentos envolvidos com a negociação desses títulos pode-se constatar que praticamente tudo é negociável, principalmente a taxa de aval, fiança ou de seguro. Basicamente, é a ficha cadastral dos clientes e as garantias aportadas que definem os termos da negociação. Dessa forma, praticamente cada operação torna-se única.

Este fato não invalida os resultados da pesquisa pois, explicita as formas alternativas e criativas desenvolvidas e adaptadas para suprir a carência de recursos para o crédito rural. No entanto, deixa claro as limitações dos resultados quantitativos deste estudo, obtidos a partir de simulações de contratos especificos, prestando-se apenas como indicativo para as operações em geral.

O CM-G foi o primeiro título com real garantia de entrega fisica da mercadoria e possibilidade de obtenção de recursos. Encontra-se atualmente com suas operações paralisadas, em parte devido ao processo de esvaziamento da Central de Registros S/A, clearing do sistema que detém o direito de uso e é a única autorizada a operar com o Certificado, após desentendimentos com sua maior acionista, a Bolsa de Cereais de São Paulo.

No entanto, na tentativa de reverter essa situação, um grupo de técnicos da Central de Registros, movimentou-se para criar uma nova clearing fisico, a Companhia Nacional de Registros, CNR, que tem como acionistas muitas agroindústrias e entidades de classes rurais. Em abril de 1996, a CNR iniciou operações com contratos CNR que tem, na essência, as mesmas caracteristicas do CM-G, mas o volume negociado ainda é muito pequeno.

O mercado de títulos agricolas no Brasil, apesar de incipiente, foi bastante estimulado a partir do início das operações com o CM-G e a CPR. Reforçado pela mudança na condução da politica agrícola que vem sendo implementada em direção à privatização dos financiamentos e comercialização, esse mercado tende a se desenvolver e se consolidar. Neste sentido, novas pesquisas nesta área contribuiriam para facilitar esse processo, na medida em que poderiam antecipar e esclarecer problemas a serem enfrentados. 
O desenvolvimento deste estudo permitiu identificar algumas questões que poderiam resultar em futuras pesquisas, e que são sugeridas a seguir.

- Identificar qual o perfil do produtor (em termos de tamanho, nivel tecnológico, etc.) e quais os produtos que viriam a utilizar-se dos títulos agricolas, e estimar qual a importância desse segmento no setor agrícola em termos do volume e valor da produção.

- Verificar como estes tipos de contratos podem diminuir a incerteza e o risco com que se deparam produtores (vendedores) e compradores dos produtos agricolas. Considerando a teoria do comportamento diante do risco, poderia-se avaliar tanto o comportamento dos vendedores e compradores envolvidos como também a redução de risco, seja do lado do produtor e/ou do comprador.

- Identificar os reais motivos que têm impedido as indústrias processadoras de matéria-prima a operar nesses mercados, pois elas se constituiriam num grande impulso para 0 seu desenvolvimento.

- Conhecer melhor as propostas e campos de atuação da nova clearing físico, a Companhia Nacional de Registros, CNR, com a oportunidade de acompanhar seu desenvolvimento e possivel consolida ção. 


\section{REFERÊNCIAS BIBLIOGRÁFICAS}

ALMEIDA, Alivinio de \& FRANCA, Terezinha J. F. Mercados financeiros rurais: alternativas para a agricultura. Informaçōes Econômicas, São Paulo, v. 23, n4, p. 25-38, abr. 1993.

ANUÁRIO ESTATISTICO DO BRASIL. Rio de Janeiro: IBGE, 1994.

ANUÁRIO ESTATISTTICO DO CRÉDITO RURAL. Brasilia: Banco Central do Brasil, DERUR, 1995.

ARAÚJO, Paulo F. Cidade \& ALMEIDA, Alivínio de. Financiamento rural nos mercados informais. In: SEMINÁRIO "AS DIFICEIS OPÇÕES DO FINANCIAMENTO RURAL NO BRASIL". Belo Horizonte, 9 -10 set 1992. Anais....Belo Horizonte: FAEMG, 1992.

BANCO CENTRAL DO BRASIL. Circular n² 2.205, de 24/07/1992.

Resolução n².294, de 28/06/1996.

BARBOSA Marisa Z;; ROCHA, Marina.B. \& FREITAS, Silene. M. de. Sazonalidade dos Preços dos principais óleos no mercado internacional. Informaçōes Econômicas, São Paulo n³, p. 9 - 18, mar.1995.

BARROS, Fritz. Taxa de inflação e financiamento rural. In: CONGRESSO BRASILEIRO DE ECONOMIA E SOCIOLOGIA RURAL, 29, Campinas, 28 jul. - 1ªgo. 1991. Anais... Brasilia: SOBER, v.2, 1991. p. $292-298$.

BOLSA DE MERCADORIAS DE SÃO PAULO. A comercialização na nova Lei Agrícola, São Paulo, s.d., $6 p$.

BOLSA DE MERCADORIAS DE SÃO PAULO. Introdução ao mercado a termo de mercadorias, São Paulo, s.d., 48 p. 
BRASIL. Lei $n^{\circ} 8.929$, de 22 de agosto de 1994. Diário Oficial da República Federativa do Brasil, n¹61, p. 12.645, 22 ago. 1994.

CAFFAGNI, Luiz C. Financiamentos Formais e Potenciais para Agropecuária: curso de comercialização de commodities agropecuárias. Piracicaba, 1994. p.25-34.

CANZIANI, J.R.F. Complexo Soja: os desafios do setor no Brasil. Óleos \& Grãos., São Paulo, v.5, n²6, p. 56-57, set/out 1995 .

CARVALHO, Maria A. de Capacidade de auto financiamento da agricultura paulista. São Paulo: IEA, 1986. 138p. (Relatónio de Pesquisa, 15/86).

CENTRAL DE REGISTROS S/A. Certificado de mercadoria com emissão garantida. São Paulo, 1995. Mimeo.

Estatuto da Central de Registros S/A, Capitulo I (a).

Regulamento do Mercado Físico, 12p (b).

COSTA, Ricardo C. da \& TOSTA, Edmar José. Armazenagem: diagnóstico e perspectiva. Revista de Economia Políica. Brasilia. ano iV, $n^{\bullet} .3$, jul-ago 1995.

DELGADO, Guilherme da C. Capital financeiro e agricultura no Brasil: 1965-1985, São Paulo: Icone/UNICAMP, 1985.236p.

DIAS, Guilherme. Avanços e perspectivas do agribusiness brasileiro. In:CONGRESSO BRASILEIRO DE ECONOMIAE SOCIOLOGIARURAL, 31, Bahia, 2-5 ago. 1993. Anais..., Brasilia: SOBER, volume 2, 1993. p. $887-895$.

ESTRAZULAS, J. Arizal. O mercado de soja no Brasil. São Paulo, BM\&F. 1994. v.2. s/p. (mimeo) 
FAGUNDES, Maria H. Comentários sobre o crédito rural e sua evolução recente, Brasilia: CFP, 1987. (Coleção de Estudos Especiais, 21).

FORBES, Luiz F. Mercados Futuros: uma introdução. São Paulo, Bolsa de Mercadorias \& Futuros, 1994.

FREITAS, et alii. Cadeia produtiva de óleos vegetais comestiveis (soja), Estudo e Análises para as Diretizes de desenvolvimento Agricola do Estado de São Paulo, Secretaria de Agricultura e Abastecimento, 1996 (versão preliminar).

FRICK, Oscar O. A Cédula de Produto Rural e os mercados derivativos. Resenha BM\&F, São Paulo, n' 103, p. 69-78, janffev 1995.

GATTI, Écio U; VIEIRA, José. L. TM.; SILVA, Valquiria da. Análise do perfil distributivo do crédito rural no Brasil, 1969-90. Agricultura em São Paulo, São Paulo, v. 40, n 1, p. 65-99, 1993.

HIERONYMUS, Thomas A. Economics of futures trading for comercial and personal profit New York, Commoditie Research Boreau, 1971, 338p.

LEVANTAMENTO SISTEMÁTICO DA PRODUÇÃO AGRICOLA. Fundação IBGE, Rio de Janeiro, dez 1994.

LOPES, Mauro R. Reformas agricolas: os custos dos ajustes parciais. Conjuntura Econômica, Rio de Janeiro, v. $48, n^{\circ} 7$, p.25-29, jul. 1994a.

Políica agricola: reformas inadiáveis e subsidios insustentáveis. Agroanalysis, Rio de Janeiro, v. $14, n^{\circ} 2$, p. $9-11$, out $1994 b$.

Os novos sistemas de financiamento das safras. Agroanalysis, Rio de Janeiro, v.14, n³, p.10-12, nov. $1994 c$. 
Reformas na comercialização devem preceder a reforma de crédito rural. Agroanalysis, Rio de Janeiro, v.14, n4, p.44-47, dez. $1994 d$.

Novos papéis para o mercado secundário de títulos. Conjuntura Econômica, Rio de Janeiro, v. 49, n¹, p.43-46, jan. 1995.

MANUAL de Commodities. Chicago: Chicago Board of trade. 1985. 390p.

MARCONI, Marina de A. \& LAKATOS, Eva M. Técnicas de pesquisa. São Paulo, Attas, 1985. 205 p.

MIGUEL, Sayde J. Crédito rural cooperativo: o banco cooperativo e a legislação do setor. In: SEMINÁRIO "AS DIFICEIS OPÇÕES DO FINANCIAMENTO RURAL NO BRASIL", Belo Horizonte, MG, 9 -10 set 1992. Anais... Minas Gerais: FAEMG, 1992.

NAKANO, Yoshiaki. O crédito rural num contexto de modernização da economia brasileira. In: SEMINÁRIO AS DIFICEIS OPÇÕES DO FINANCIAMENTO RURAL NO BRASIL, Belo Horizonte, MG, $9-10$ set 1992. Anais... Minas Gerais: FAEMG, 1992.

NEVES, Evaristo M. Caracteristicas da agricultura. Piracicaba, São Paulo. ESALQ/USP, 1987. 22 p.

NÓBREGA, Mailson da. A necessidade da criação de fontes não inflacionarias, permanentes e definitivas para financiar a agricultura brasileira In: SEMINÁRIO "AS DIFICEIS OPÇÕES DO FINANCIAMENTO RURAL NO BRASIL”, Belo Horizonte, MG, 9 -10 set 1992. Anais... Minas Gerais: FAEMG, 1992.

NÓBREGA, Mailson da. Novas formas de financiar a agricultura. Agroanalysis, Rio de Janeiro v.14, $n^{\circ} 3$, p. 2-5, nov. 1994.

NUEVO, Paulo. A Cédula de Produto Rural (CPR) como alternativa para financiamento da produção agropecuária. Piracicaba, 1996. 105p. (Mestrado - Escola Superior de Agricultura "Luiz de Queiroz"/USP). 
OKAWA. Hiroshige. Curso de administração rural - Módulo: matemática financeira. Instituto de Economia Agricola, s.d. 66p.

PANHOCA, Heraldo. CM-G Teoria e Prática, incluso cláusula CM-G termo, mimeo, São Paulo, 1996.

PRADO, Joaquim A. de A.

REQUIÃO, Rubens. Curso de Direito Comercial, v.2, Saraiva, São Paulo, 1988. (17. a edição)

RIBEIRO, D.; PANHOCA, H.; TEIXEIRA, C.; A modernidade nos sistemas de produção e distribuição no Brasil: Certificado de Mercadoria com Emissão Garantida. Revista de Administração, São Paulo, v.30, n.4, p.91-97, SP, outddez. 1995.

SANDRONI, Paulo. Dicionário de Economia. São Paulo. Abril Cultural. 1985. 459p.

SAYAD, João. Crédito rural no Brasil: avaliação das criticas e das propostas de reforma. São Paulo: FIPE/Pioneira, 1984.

SCHOUCHANA, Felix. Mercados futuros e de opçoes agropecuárias: teoria e prática. São Pau10:BM\&F, s.d., 36p. mimeo(a)

Soja. Bolsa de Mercadorias e Futuros, São Paulo: BM\&F, s.d.. 48p. mimeo (b).

SEMINARIO AS DIFICEIS OPÇŐES DO FINANCIAMENTO RURAL NO BRASIL,. Belo Horizonte, 1992. Anais . Belo Horizonte, FAEMG, 1992. 114p.

SHIROTA, R. Crédito rural no Brasil: subsídio, distribuiçào e fatores associados à oferta. Piracicaba, 1988. 230p. (Mestrado - Escola Superior de Agricultura "Luiz de Queiroz"/USP). 
SOARES, Marden M. Cooperativas de crédito e as novas normas (Res.1914/92). In: SEMINÁRIO AS DIFICEIS OPÇÕES DO FINANCIAMENTO RURAL NO BRASIL, Belo Horizonte, MG, 9 -10 set 1992. Anais... Minas Gerais, FAEMG, 1992.

SOBOLL, Walter. Novos caminhos para o financiamento da produção agropecuária. São Paulo em Perspectiva, São Paulo, v.7, n4, p. 85-93, jul/set 1993.

O novo mercado mercantil-financeiro: uma saida para a agricultura. Agroanalysis, Rio de Janeiro, v.14, nº4, p. 76, dez. 1994.

A reorganização do mercado fisico agropecuário. "s.n.t." $4 p$.

STADUTO, Jeferson A. R. O mercado de opções agricolas: uma alternativa de financiamento para a agricultura. Minas Gerais, 1995. 123p. (Mestrado - Universidade Federal de Viçosa).

STADUTO, Jeferson A. R.; MARQUES, Pedro V. Os certificados de mercadoria. Preços Agricolas, Piracicaba ,(101), p. 8-9, mar. 1995.

SUPERINTENDÊNCIADE SEGUROS PRIVADOS (SUSEP), Circular nº 26, 1989.

TSUNECHIRO Alfredo. O desempenho dos mercados a termo: os casos do café, soja e boi gordo na Bolsa de Mercadorias de São Paulo. São Paulo: IEA, 1986. 123p. (Relatório de Pesquisa, 18/86).

TSUNECHIRO Alfredo et alii. Prognóstico Agricola 1995/96: algodão, amendoim, arroz, fejãa, mandioca, milho, soja. Informações Econômicas, São Paulo, v.25, n.9, p. 13-71, set 1995.

Prognóstico Agricola 1996/97: algodão, arroz, feijão, milho, soja. Informações Econômicas, v. $26 n^{\circ} .8$, ago. 1996.

VIEIRA SOBRINHO, José D. Matemática Financeira. 2.ed. São Paulo: Atlas, 1992. 
APÊNDICES 
Apêndice 1 - Preço da soja em grão no mercado futuro da Bolsa de Mercadorias de Chicago (CBOT), US\$ cents/bushel

\begin{tabular}{ccccc}
\hline \multirow{2}{*}{ Data } & \multicolumn{2}{c}{ Vencimento em março } & \multicolumn{2}{c}{ Vencimento em maio } \\
\cline { 2 - 5 } & fechamento & prêmio & fechamento & prèmio \\
\hline 24/out/94 & 574,75 & 17,00 & 582,50 & 10,00 \\
$01 /$ nov/94 & 564,75 & 18,00 & 573,25 & 12,00 \\
$01 / 03 / 95$ & 553,75 & 21,00 & 563,50 & 16,00 \\
19/se/95 & 674,25 & 15,00 & 679,75 & 10,00 \\
$01 /$ nov/95 & 699,00 & 16,00 & 702,75 & 12,00 \\
01/fev/96 & 741,00 & 25,00 & 746,50 & 19,00 \\
18/se/96 & 808,00 & $(11,00)$ & 806,00 & $(12,00)$ \\
\hline
\end{tabular}

Fonte: Bolsa de Mercadorias de Chicago (CBOT); Safras \& Mercado, Publicação Semanal Sobre Tendências de Mercado: Soja 
Apêndice 2- Taxa de câmbio comercial (R\$/US\$).

\begin{tabular}{cc}
\hline Data & R\$NS $\$$ \\
\hline $24 / 10 / 94$ & 0,853 \\
$01 / 111 / 94$ & 0,845 \\
$01 / 03 / 95$ & 0,850 \\
$19 / 09 / 95$ & 0,953 \\
$01 / 11 / 95$ & 0,963 \\
$01 / 02 / 96$ & 0,979 \\
$18 / 09 / 96$ & 1,020 \\
\hline
\end{tabular}

Fonte: Economia em Perspectiva, $n^{\circ}$ 135-out./96

${ }^{1}$ Cotação do preço de venda do dia. 
Apêndice 3 - Operação 1/Safra 94/95

Decomposição do preço futuro da soja em grãos da CBOT para preço futuro FOB/Paranaguá (PFOBPAR).

Paridade para exportação preço FOB/Paranaguá

$24 / 10 / 94$

$1 / 11 / 94$

$1 / 3 / 95$

Base março/95 Base maio/95 Base março/95 Base maio/95 Base março/95 Base maio/95

\begin{tabular}{|c|c|}
\hline Fechamento CBOT & (US\$ cents/bushel) \\
\hline Prêmio/Desconto & (US\$ cents/bushel) \\
\hline Conversão - US\$/ton. & $($ fator $=36.7454)$ \\
\hline Conversão - US\$/sc & (fator $=16,666)$ \\
\hline Cọversão - R\$/sc & \\
\hline Receita Bruta & (US\$/tonelada) \\
\hline Despesas & \\
\hline ICMS & ( $13 \%$ sobre a rec. bruta) \\
\hline Fretes & (US\$/tonelada) \\
\hline Despesas Porto & (US\$7,00/tonelada) \\
\hline PIS & (0,65\% sobre a rec. bruta; cooperativas isentas) \\
\hline Taxas/Comissões & (US $\$ 0,50 /$ tonelada) \\
\hline Corret. Câmbio & $(0,1875 \%$ sobre a rec. bruta) \\
\hline COFINS & ( $2,00 \%$ sobre a rec. bruta, só p. o mercado interno) \\
\hline Despesa Total & (US\$/tonelada) \\
\hline Receita Líquida & (US\$/tonelada) \\
\hline Receita Líquida & (US\$/saca de $60 \mathrm{~kg}$ ) \\
\hline Relação Cambial & $(\mathrm{R} \$ /$ US $\$)$ \\
\hline Receita Líquida & (R\$/saca de $60 \mathrm{~kg})$ \\
\hline
\end{tabular}

\begin{tabular}{rrrrrr}
574,75 & 582,50 & 564,75 & 573,25 & 553,75 & 563,50 \\
17,00 & 10,00 & 18,00 & 12,00 & 21,00 & 16,00 \\
217,44 & 217,72 & 214,13 & 215,05 & 211,19 & 212,94 \\
13,05 & 13,06 & 12,85 & 12,90 & 12,67 & 12,78 \\
11,13 & 11,14 & 10,86 & 10,90 & 10,77 & 10,86 \\
217,44 & 217,72 & 214,13 & 215,05 & 211,19 & 212,94 \\
& & & & & \\
28,27 & 28,30 & 27,84 & 27,96 & 27,46 & 27,68 \\
18,00 & 18,00 & 18,00 & 18,00 & 18,00 & 18,00 \\
7,00 & 7,00 & 7,00 & 7,00 & 7,00 & 7,00 \\
1,41 & 1,42 & 1,39 & 1,40 & 1,37 & 1,38 \\
0,50 & 0,50 & 0,50 & 0,50 & 0,50 & 0,50 \\
0,41 & 0,41 & 0,40 & 0,40 & 0,40 & 0,40 \\
- & - & - & - & - & - \\
55,59 & 55,63 & 55,13 & 55,26 & 54,72 & 54,97 \\
161,85 & 162,09 & 159,00 & 159,79 & 156,47 & 157,97 \\
9,71 & 9,73 & 9,54 & 9,59 & 9,39 & 9,48 \\
0,853 & 0,853 & 0,845 & 0,845 & 0,850 & 0,850 \\
8,28 & 8,30 & 8,06 & 8,10 & 7,98 & 8,06 \\
\hline & & & & &
\end{tabular}


Apêndice 4 - Operação 2/safra 95/96

Decomposição do preço futuro da soja em grãos da CBOT para preço futuro FOB/Paranaguá (PFOBPAR).

Paridade para exportação preço FOB/Paranaguá

19/09/95

$1 / 11 / 95$

$1 / 02 / 96$

Base março/96 Base maio/96 Base março/96 Base maio/96 Base março/96 Base maio/96

\begin{tabular}{|c|c|}
\hline Fechamento CBOT & (US $\$$ cents/bushel) \\
\hline Prêmio/Desconto & (US $\$$ cents/bushel) \\
\hline Conversão - US\$/ton. & (fator $=36.7454)$ \\
\hline Conversão - US\$/sc & (fator $=16,666)$ \\
\hline Conversão- $\mathrm{R} \$ / \mathrm{sc}$ & \\
\hline Receita Bruta & (US\$/tonelada) \\
\hline Despesas & \\
\hline ICMS & ( $13 \%$ sobre a rec. bruta) \\
\hline Fretes & (US\$/tonelada) \\
\hline Despesas Porto & (US $\$ 7,00 /$ tonelada) \\
\hline PIS & $(0,65 \%$ sobre a rec. bruta; cooperativas isentas $)$ \\
\hline Taxas/Comissões & (US\$ 0,50/tonelada) \\
\hline Corret. Câmbio & $(0,1875 \%$ sobre a rec. bruta) \\
\hline COFINS & ( $2,00 \%$ sobre a rec. bruta, só p. o mercado interno) \\
\hline Despesa Total & (US\$/tonelada) \\
\hline Receita Líquida & (US\$/tonelada) \\
\hline Receita Líquida & (US\$/saca de $60 \mathrm{~kg}$ ) \\
\hline Relação Cambial & (R\$/US\$) \\
\hline Receita Líquida & $(\mathrm{R} \$ / \mathrm{saca}$ de $60 \mathrm{~kg})$ \\
\hline
\end{tabular}

Fonte: Estrázulas (1995), Safras \& Mercado (1996), Nuevo (1986).

\begin{tabular}{rrrrrr}
674,25 & 679,75 & 699,00 & 702,75 & 741,00 & 746,50 \\
15,00 & 10,00 & 16,00 & 12,00 & 25,00 & 19,00 \\
253,27 & 253,45 & 262,73 & 262,64 & 281,47 & 281,29 \\
15,20 & 15,21 & 15,76 & 15,76 & 16,89 & 16,88 \\
14,48 & 14,49 & 15,18 & 15,18 & 16,53 & 16,52 \\
253,27 & 253,45 & 262,73 & 262,64 & 281,47 & 281,29 \\
& & & & & \\
32,92 & 32,95 & 34,15 & 34,14 & 36,59 & 36,57 \\
20,00 & 20,00 & 20,00 & 20,00 & 20,00 & 20,00 \\
7,00 & 7,00 & 7,00 & 7,00 & 7,00 & 7,00 \\
1,65 & 1,65 & 1,71 & 1,71 & 1,83 & 1,83 \\
0,50 & 0,50 & 0,50 & 0,50 & 0,50 & 0,50 \\
0,47 & 0,48 & 0,49 & 0,49 & 0,53 & 0,53 \\
- & - & - & - & - & - \\
62,55 & 62,57 & 63,86 & 63,84 & 66,45 & 66,42 \\
190,72 & 190,88 & 198,87 & 198,80 & 215,02 & 214,86 \\
11,44 & 11,45 & 11,93 & 11,93 & 12,90 & 12,89 \\
0,953 & 0,953 & 0,963 & 0,963 & 0,979 & 0,979 \\
10,91 & 10,91 & 11,49 & 11,49 & 12,63 & 12,62 \\
\hline
\end{tabular}




\begin{tabular}{|c|c|c|c|}
\hline & $\begin{array}{l}\text { Composição do preço futuro da soja em grâ } \\
\text { B/Paranaguá (PFOBPAR). }\end{array}$ & s da CBOT & ra preço futur \\
\hline \multicolumn{2}{|c|}{ Paridade para exportação preço FOB/Paranaguá } & \multicolumn{2}{|c|}{ 18/09/96 } \\
\hline & & Base março/97 & Base maio/97 \\
\hline Fechamento CBOT & (US\$ cents/bushel) & 808,00 & 806,00 \\
\hline Prêmio/Desconto & (US\$ cents/bushel) & $(11,00)$ & $(12,00)$ \\
\hline Conversāo - US\$/ton. & $($ fator $=36.7454)$ & 292,86 & 291,76 \\
\hline Conversão - US\$/sc & (fator $=16,666$ ) & 17,57 & 17,51 \\
\hline Conversão - R\$/sc & & 17,92 & 17,86 \\
\hline Receita Bruta & (US\$/tonelada) & 292,86 & 291,76 \\
\hline \multicolumn{4}{|l|}{ Despesas } \\
\hline ICMS & (13\% sobre a rec. bruta) & 38,07 & 37,93 \\
\hline Fretes & (US\$/tonelada) & 20,00 & 20,00 \\
\hline Despesas Porto & (US $\$ 7,00 /$ tonelada) & 7,00 & 7,00 \\
\hline PIS & ( $0,65 \%$ sobre a rec. bruta; cooperativas isentas) & 1,90 & 1,90 \\
\hline Taxas/Comissões & (US\$ 0,50/tonelada) & 0,50 & 0,50 \\
\hline Corret. Câmbio & $(0,1875 \%$ sobre a rec. bruta) & 0,55 & 0,55 \\
\hline COFINS & (2,00\% sobre a rec. bruta, só p. o mercado interno) & - & - \\
\hline Despesa Total & (US\$/tonelada) & 68,02 & 67,87 \\
\hline Receita Liquida & (US\$/tonelada) & 224,84 & 223,89 \\
\hline Receita Líquida & (US\$/saca de 60.kg) & 13,49 & 13,43 \\
\hline Relação Cambial & (R\$/US\$) & 1,020 & 1,020 \\
\hline Receita Líquida & $(\mathrm{R} \$ / \mathrm{saca}$ de $60 \mathrm{~kg})$ & 13,76 & 13,70 \\
\hline
\end{tabular}

Fonte: Estrázulas (1995), Safras \& Mercado (1996), Nuevo (1986). 
Apêndice 6 - Preço futuro da soja FOB/Paranaguá decomposto para o valor de negociação antecipado através da Cédula de Produto Rural (CPR ) e do Certificado de Mercadoria com Emissão Garantida (CMFG).

\begin{tabular}{|c|c|c|c|c|c|c|c|c|}
\hline \multirow{2}{*}{$\begin{array}{c}\begin{array}{c}\text { No da } \\
\text { operação } \\
\text { (iniclvenc) }\end{array} \\
1\end{array}$} & \multirow[t]{2}{*}{$\begin{array}{l}\text { Data de } \\
\text { lib. dos } \\
\text { recursos }\end{array}$} & \multicolumn{2}{|c|}{$\begin{array}{c}\text { PFOBPAR } \\
\text { Preço fut. FOB/Paranaguá } \\
\text { (na data de lib. dos rec.) } \\
(\mathrm{R} \$ / \mathrm{sc})\end{array}$} & \multirow{2}{*}{$\begin{array}{c}\text { Ck } \\
\text { C. de oport. } \\
\text { do capital1 } \\
\text { (\%/mès) } \\
\text { - }\end{array}$} & \multicolumn{2}{|c|}{$\begin{array}{c}\mathrm{N} \\
\text { No de dias } \\
\text { (inicio/venc) }\end{array}$} & \multicolumn{2}{|c|}{$\begin{array}{c}V n \\
\text { Valor de negociaçäo da } \\
\text { CPR e do CMFG } \\
(\mathrm{R} \$ / \mathrm{sc}) \\
\end{array}$} \\
\hline & & (março/95) & (maio/95) & & (março/95) & (maio/95) & (março/95) & (maio/95) \\
\hline \multicolumn{9}{|l|}{ out/94 } \\
\hline mar/95 & $24 / 10 / 94$ & 8,28 & 8,30 & 2,9512 & 141 & 202 & 7,23 & 6,82 \\
\hline ou & $01 / 11 / 94$ & 8,06 & 8,10 & 3,0678 & 133 & 194 & 7,05 & 6,66 \\
\hline $\mathrm{mai} / 95$ & $01 / 03 / 95$ & 7,98 & 8,06 & 2,3623 & 13 & 74 & 7,90 & 7,61 \\
\hline 2 & & (março/96) & (maio/96) & - & (março/96) & (maio/96) & (março/96) & (maio/96) \\
\hline set/95 & & & & & & & & \\
\hline mar/96 & $19 / 09 / 95$ & 10,91 & 10,92 & 3,1175 & 183 & 244 & 9,04 & 8,50 \\
\hline ou & $01 / 11 / 95$ & 11,49 & 11,49 & 2,1623 & 140 & 201 & 10,40 & 9,95 \\
\hline mail96 & $01 / 02 / 96$ & 12,63 & 12,62 & 1,7589 & 48 & 109 & 12,28 & 11,85 \\
\hline $\begin{array}{c}3 \\
\text { set/96 }\end{array}$ & & (março/97) & (maio/97) & - & (março/97) & (maio/97) & (março/97) & (maio/97) \\
\hline $\begin{array}{c}\mathrm{mar} / 97 \\
\text { ou } \\
\mathrm{mai} / 97\end{array}$ & $18 / 09 / 96$ & 13,76 & 13,70 & 1,1306 & 183 & 244 & 12,85 & 12,50 \\
\hline
\end{tabular}

Fonte: Dados da pesquisa.

${ }^{1}$ Taxa da poupança do mès de liberação dos recursos. 
Apêndice 7 - Valor liquido da Cédula de Produto Rural (CPR).

\begin{tabular}{|c|c|c|c|c|c|c|c|c|c|}
\hline $\begin{array}{c}\text { No da } \\
\text { operação } \\
\text { (inic.Nenc) }\end{array}$ & $\begin{array}{l}\text { Data de } \\
\text { lib. dos } \\
\text { recursos }\end{array}$ & \multicolumn{2}{|c|}{$\begin{array}{c}\text { Vn } \\
\text { Valor de negociação } \\
\text { da CPR } \\
(\mathrm{R} \$ / \mathrm{sc}) \\
\end{array}$} & $\begin{array}{c}\text { Ca } \\
\text { C.do aval } \\
(\%) \\
\end{array}$ & \multicolumn{2}{|c|}{$\begin{array}{c}n \\
\text { No de meses } \\
\text { pl efeito de aval }\end{array}$} & $\begin{array}{c}\text { Ctx } \\
\text { C.de oper. } \\
\text { em bolsa } \\
(\%) \\
\end{array}$ & \multicolumn{2}{|c|}{$\begin{array}{c}\text { VliqCPR } \\
\text { NnCPR-custos) } \\
\text { (R\$/sc) } \\
\end{array}$} \\
\hline 1 & & (março/95) & (maio/95) & - & (março/95) & (maio/95) & - & (março/95) & (maio/95) \\
\hline \multicolumn{10}{|l|}{ out/94 } \\
\hline mar/95 & $24 / 10 / 94$ & 7,23 & 6,82 & 0,65 & 5 & 7 & 0,60 & 6,95 & 6,47 \\
\hline ou & $01 / 11 / 94$ & 7,05 & 6,66 & 0,65 & 4 & 6 & 0,60 & 6,82 & 6,36 \\
\hline $\mathrm{mai} / 95$ & $01 / 03 / 95$ & 7,90 & 7,61 & 0,45 & 1 & 3 & 0,60 & 7,82 & 7,46 \\
\hline \multicolumn{9}{|l|}{ set/95 } & (maio/96) \\
\hline $\operatorname{mar} / 96$ & $19 / 09 / 95$ & 9,04 & 8,50 & 0,65 & 6 & 8 & 0,60 & 8,64 & 8,01 \\
\hline ou & $01 / 11 / 95$ & 10,40 & 9,95 & 0,65 & 4 & 6 & 0,60 & 10,07 & 9,50 \\
\hline mai/96 & $01 / 02 / 96$ & 12,28 & 11,85 & 0,45 & 1 & 3 & 0,60 & 12,15 & 11,62 \\
\hline 3 & & (março/97) & (maio/97) & - & (março/97) & (maio/97) & - & (março/97) & (maio/97) \\
\hline set/96 & & & & & & & & & \\
\hline $\mathrm{mar} / 97$ & $18 / 09 / 96$ & 12,85 & 12,50 & 0,65 & 6 & 8 & 0,60 & 12,27 & 11,78 \\
\hline ou & & & & & & & & & \\
\hline mai/97 & & & & & & & & & \\
\hline
\end{tabular}

Fonte: Dados da pesquisa. 
Apêndice 8 - Valor liquido do Certificado de Mercadoria com Emissão Garantida (CMFG).

\begin{tabular}{|c|c|c|c|c|c|c|c|c|c|c|}
\hline $\begin{array}{c}N^{0} \text { da } \\
\text { operação } \\
\text { (iniclvenc) }\end{array}$ & $\begin{array}{l}\text { Data de } \\
\text { lib. dos } \\
\text { recursos }\end{array}$ & \multicolumn{2}{|c|}{$\begin{array}{c}\text { Vn } \\
\text { Valor de negociação } \\
\text { do CMFG } \\
(R \$ / s c) \\
\end{array}$} & $\begin{array}{l}\text { Cf } \\
\text { Custo } \\
\text { Fiança } \\
(\% \text { aa })\end{array}$ & \multicolumn{2}{|c|}{$\begin{array}{c}\mathrm{N} \\
\mathrm{N}^{0} \text { de dias } \\
\text { (inicio/venc.) }\end{array}$} & $\begin{array}{c}\text { Cs } \\
\text { Custo do } \\
\text { SGOC } \\
\text { (\% aa) }\end{array}$ & $\begin{array}{c}\text { Clx } \\
\text { C. oper. } \\
\text { em bolsa } \\
(\%)\end{array}$ & \multicolumn{2}{|c|}{$\begin{array}{c}\text { VliqCMFG } \\
\text { (VnCMFG-custos) } \\
(\mathrm{R} \$ / \mathrm{sc})\end{array}$} \\
\hline $\begin{array}{c}1 \\
\text { out/94 }\end{array}$ & - & (março/95 & (maio/95) & - & (março/95 & (maio/95) & - & - & (março/95 & (maio/95) \\
\hline mar/95 & $24 / 10 / 94$ & 7,23 & 6,82 & 6,00 & 141 & 202 & 0,00 & 1,05 & 6,98 & 6,52 \\
\hline ou & $01 / 11 / 94$ & 7,05 & 6,66 & 6,00 & 133 & 194 & 0,00 & 1,05 & 6,82 & 6,38 \\
\hline mai/95 & $01 / 03 / 95$ & 7,90 & 7,61 & 6,00 & 13 & 74 & 0,00 & 1,05 & 7,80 & 7,43 \\
\hline $\begin{array}{c}2 \\
\text { set/95 }\end{array}$ & - & (março/96 & (maio/96) & - & (março/96 & (maio/96) & - & - & (março/96 & (maio/96) \\
\hline mar/96 & $19 / 09 / 95$ & 9,04 & 8,50 & 6,00 & 183 & 244 & 0,00 & 1,05 & 8,68 & 8,07 \\
\hline ou & $01 / 11 / 95$ & 10,40 & 9,95 & 6,00 & 140 & 201 & 0,00 & 1,05 & 10,05 & 9,52 \\
\hline $\mathrm{mai} / 96$ & $01 / 02 / 96$ & 12,28 & 11,85 & 6,00 & 48 & 109 & 0,00 & 1,05 & 12,06 & 11,51 \\
\hline $\begin{array}{c}3 \\
\text { set/96 }\end{array}$ & - & (março/97 & (maio/97) & - & (março/97 & (maio/97) & - & - & (março/97 & (maio/97) \\
\hline $\begin{array}{l}\text { mar/97 } \\
\text { ou } \\
\text { mai/97 }\end{array}$ & $18 / 09 / 96$ & 12,85 & 12,50 & 6,00 & 183 & 244 & 3,25 & 1,05 & 12,30 & 11,97 \\
\hline
\end{tabular}

Fonte: Dados da pesquisa.

${ }^{1}$ Seguro Garantia de Obrigações Contratuais. 
Apêndice 9 - Equivalente sacas dos recursos necessários para custeio de soja de acordo com os contratos CPR e CMFG

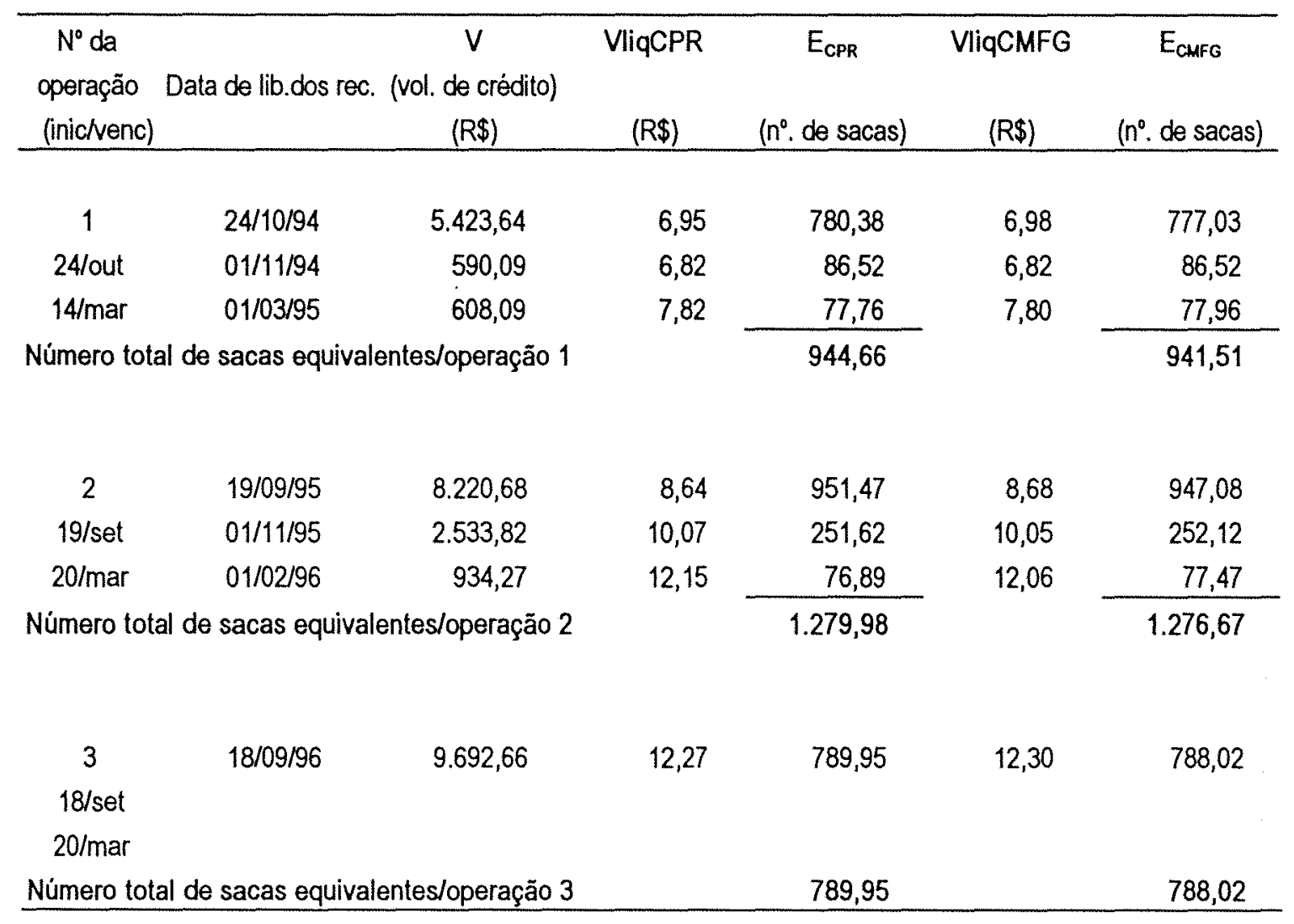

Fonte: Elaborado com base nas Tabelas 15, 16, 17 e 18. 
Apêndice 10 - Equivalente sacas dos recursos necessários para custeio de soja de acordo com o contrato do Sistema Nacional de Crédito Rural (SNCR)

\begin{tabular}{|c|c|c|c|c|c|}
\hline $\begin{array}{l}\mathrm{N}^{0} \mathrm{da} \\
\text { operação } \\
\text { (inic/venc) }\end{array}$ & Data de lib.dos rec. & $\begin{array}{c}\mathrm{V} \\
\text { (vol. de crédito) } \\
\text { (R\$) } \\
\end{array}$ & & $\begin{array}{c}\text { PFOBPAR }^{1} \\
(\mathrm{R} \$) \\
\end{array}$ & $\begin{array}{c}\mathrm{E}_{\mathrm{SNCR}} \\
\text { (número de sacas) }\end{array}$ \\
\hline 1 & $24 / 10 / 94$ & Total $(A+B+C)$ & $7.767,60$ & 8,28 & 938,12 \\
\hline $24 /$ out & & Principal (A) & $6.621,82$ & & 799,74 \\
\hline \multirow[t]{2}{*}{$14 /$ mar } & & Juros (B) & 313,04 & & 37,81 \\
\hline & & Correção $(C)$ & 832,74 & & 100,57 \\
\hline 2 & $19 / 09 / 95$ & Total $(A+B+C)$ & $12.507,26$ & 10,91 & $1.146,40$ \\
\hline$\cdot 19 / \mathrm{set}$ & & Principal (A) & $11.688,77$ & & $1.071,38$ \\
\hline \multirow[t]{2}{*}{$20 /$ mar } & & Juros (B) & 818,49 & & 75,02 \\
\hline & & Correção (C) & 0,00 & & 0,00 \\
\hline 3 & 18/09/96 & Total $(A+B+C)$ & $10.270,12$ & 13,76 & 746,38 \\
\hline $18 /$ set & & Principal (A) & $9.692,66$ & & 704,41 \\
\hline \multirow[t]{2}{*}{$20 / \mathrm{mar}$} & & Juros $(B)$ & 577,46 & & 41,97 \\
\hline & & Correção (C) & 0,00 & & 0,00 \\
\hline
\end{tabular}

Fonte: Elaborado com base nas Tabelas 15, 16, 17 e 18.

${ }^{1}$ Foi utilizado o PFOPAR para a data de liberação da maior parcela de recursos. Considerou-se que este seria representativo do preço recebido pelo produtor logo após a colheita (março) 
Apêndice 11 - Certificado de Mercadoria com Emissão Garantida - Entrega Física Disponivel CMDG.

Apêndice 12 - Boleto de Negociação - Certificado de Mercadoria com Emissão Garantida - Entrega Fisica Disponivel - CMDG.

Apêndice 13 - Certificado de Mercadoria com Emissão Garantida - Entrega Futura Garantida CMFG.

Apêndice 14 - Boleto de Negociação - Certificado de Mercadoria com Emissão Garantida - Entrega Futura Garantida - CMFG.

Apêndice 15 - Acordo de Cliente e Instrumento de Mandato 


\section{CERTIFICADO DE MERCADORIA \\ COM EMISSĀO GARANTIDAQ}

Entrega Fislca - Disponivel - CMDG

Produtos Agrícolas - Pecuárlos - Agro-Industrials

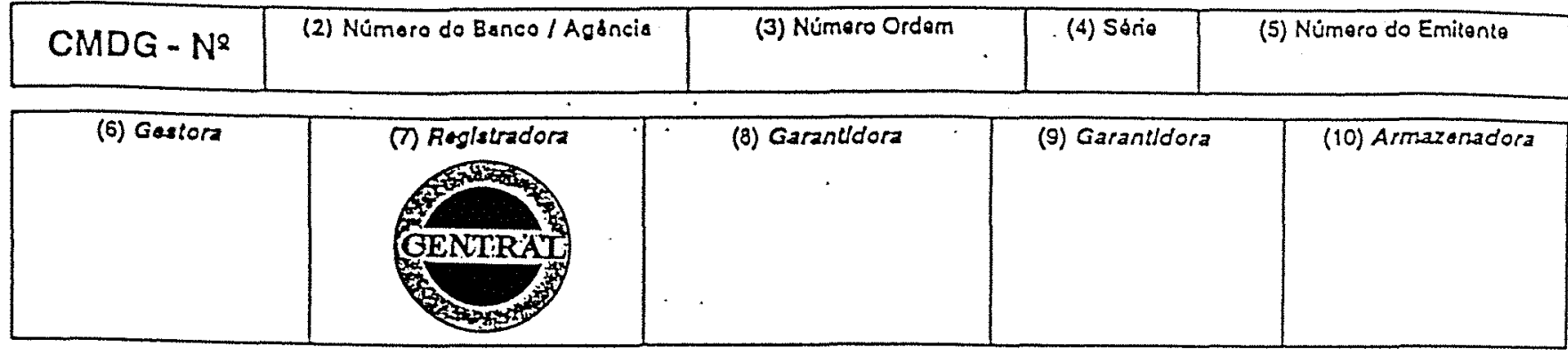

\section{EMITENTE - VENDEDOR}

(11) Nome ou Razão Social:

inser. Estadual / Produtor.

(12) C.Q.C/C.P.F.:

(13) Endereço:

(14) Cidade:

(15) UF:

\section{CLASSIFICAÇĀO DA MERCADORIA}

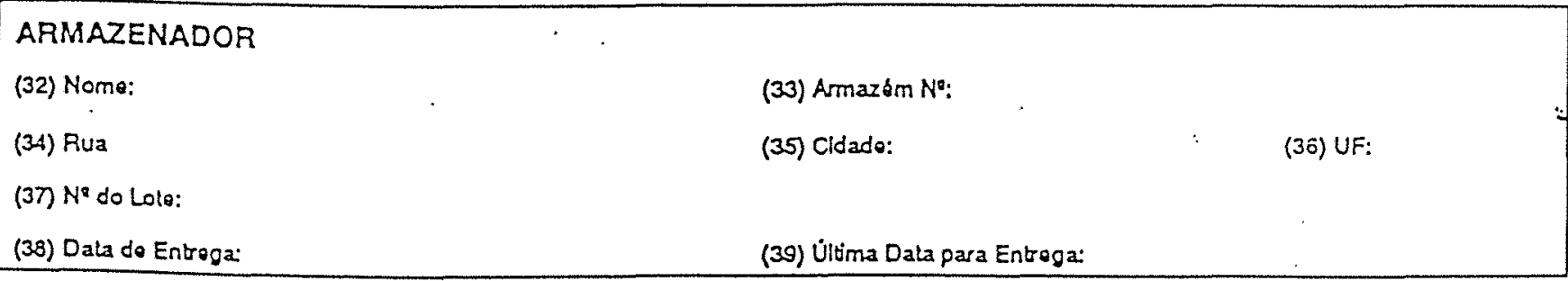

\section{GARANTIDOR COOBRIGADO}

(40)

(41) Aosincla:

(42) CGCMF:

(43) Cidada:

(44) UF:

\section{GESTORA DOS NEGÓCIOS}

\section{REGISTRADOR - COMPENSADOR - LIQUIDADOR}

CENTRAL DE REGISTROS SA.

CGC.MF.: $60.158 .8350001-84$

Av. Senador Quelroz, $611-2^{2}$ andar - Så Faulo - SP

Pelo presente Instrumento particular e para todos os fin's de direito, o Emitente Vendedor e seus Garantidores Co-obrigados, acima nomeados $\theta$ Identificados, se comprometem a Vender $\theta$ a Entregar a mercadoria depositada no Armazenador, acima identrificado, em conformidade com o termo de classificaçāo, nos prazos e condiçōes contantes deste Instrumento, e do Boleto de Venda emitido nos pregöes da Bolsa, ao Comprador, $\theta$ que também ficam sujeitas às seguintes cláusulas e condiçöes : (verso) 
1.0 prosento lnstumento vam emitido polo Emitento-Vendodor, $\infty \mathrm{m}$ a garantia do co-obrigaça do cumprimento das clàisulas inorentes à

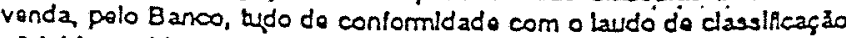
ońcial fomecido pelas órgazos ts cnicos crodenciados pola Bolsa.

2Esto Certícado de Mercadoria somento podera ser"negoclado nos pregoes tivres a regulares das Bolsas o outras congenners, no pal's e no exiorior, sendo a revenda elou tansleráncla de tibiaridade por rogis to escribural funto a Central de Registios S/A, tudo conlorme seus estatules e regulamentos.

3.A venda do presente cortificado, tivre de qualsquer onus ou gravamos, será roalizada nos tormos do Acordo de Cllontes . condiçöes negoclals firmado abravés das Soclodades Corrotoras oncla's. nas pregöas da Bolsa.

4.Sobre a negocią̧ăo do presente certificado Incidirăo taxas, emolumentas a comisozos nogocials, que seräo suportadas polas partas - Vendador o Comprador, tudo conlorme tabola periodlcamento ocitada o frada pola Cental do Registos SIA.

5.Este Cortificado de Mercadoria permanecerà custodlado desde a dala de sua omissào aló a dala da olotiva robirada da mercadoria polo

- comprador final, Junto à agdncia bancárla co-obrigada do emitento, quando perdara sua validado, pelo vencimento.

6.0 amazenador ldentificaco no anverso fica investido de lodas as obrigaçöas que sào abibuidas pela lel ao fiel depositátio, Inclustivo a de manutançăo da mercadoria no estado de conservaçăo, conforme alastado no laudo classificatório reproduzido a a sio lcluso.

7.Sảo de responsabilidade do Emitento-Vendocor lodas as despesas decorrontes, alé a data da. pitmeira venda do Cortífado, sucossivamente, dos bitures Vendedores (orórata-tempore), salvo" condiçöes negociais em contrário.

8.Os impostos, se Incidenles, Inclusive sou recolhimento ou ressarcimento, seräo de responsabilidade do Comprador, salvo disposiçäo em contrário provista om legislação.

9.Ficam lazendo parte Integrante desto Certificado as seguintes documentos, que as partes declaram expressamento o conheclmonlo. obodiencia a todos as sous termos, clausulas o condlģäs: a) Laudo de Claselficação de Misrcadoria

-b) Acordo do Cliente

c) Estatulo da Bols a e seus regulamentos

d) Rogulamentos da Central do Ragistros S/A

-) Regulamentos do Amazenador

DApollees de Seguros

o) Contralos aditivos entre co-obrigados a Emitentas-Vendedores, se oxistontes

h) Contralos adibivos entro Compradores a Central de Registros S/A Doolelo de Nagociaçào

10.0s co-obrigados garantidores do Emitente-Vendedor, a fola ordem, se compromelem a oletuar o pagamento da regosição da mercadoria objolo desto Certificado om ale 24 (vinle o quatro) horas apbs declarado o Inadimplemento do Emitento-Vendedor cu do Amazenador.

11 A Cental de Registos S/A sorà a Administradora das garantias des Contratanles-Compradores, se comprometendo a repassar a llquldaçăo do valor consiante da venda do presente Cerificado, no mesmo prazo definido na cláusula 10.

12A mercadoria a ser entregue, obedecerà as especificaçöes do padrào de qualidade constante no anverso, conforme limita de teleràncla estabelecido pela respectiva Camara de Produtas da Bolsa.

13.Fica Instbuido, como primeira Instancia cbrigatoria o Juizo Arbital da Bolsa, para dirimir quaisquer divorgancias surgidas no eumprimento das cláusulas do presente instumento.

14.Caso qualquer autoridade federal, estadual ou municipal venha - ditar norma legal que afolo, em parte ou no todo, substancialmente a direitos o obrigaçzos criados pelo presente Certificado, esta poderá sor considerado rescindido, precedendo-se, de lmediato, sua liquldaçăo compulsória caso, a critário das partes, não seja oncontrada soluçào amistosa, sem prejuizo dos dirsitos o obrigaçöes anteriomenle assumidas.

15.Em caso de extravio ou destruiçảo do presente Certificado. o Emilento-Vendodor, o Amazenador o o Cuslodiador final, deverào comunicar prontamente, por escrito, à Central de Registros S/A para - consequento cancolamento o autotiząào para omissào de segunda via $O$ nảo cumprimento do disposto no caput desto artigo para fins de diroito o garanba do terceires, prevalecerá o registo oscritural funto a Contral de Registos S/A.

E POR ESTAREM JUSTO E CONTRATADOS, FIRMAM O RRESENTE EM TODOS OS SEUS TERMOS, PARA OS DEVIDOS FINS DE DIREITO.

Praça- Estado Dala do Emissão do Cortícado

\begin{tabular}{|c|c|}
\hline Assinatura do Emitento Vendedor & $\begin{array}{l}\text { A Bolsa no anverso Identificada signataria de contalo especifico } \\
\text { onde assume responsabilidades perante os contatantes, por firma } \\
\text { ou chancela nele constanle, sobre: }\end{array}$ \\
\hline Assinabura do Armazenador & $\begin{array}{l}\text { a) Irvro participação nos pregōes regulares, por seus correlores; } \\
\text { b) Julzado do Pandenclas, ou Arbitral, por sou corpo próprio; }\end{array}$ \\
\hline Assinabura do Co-obrigado Garantidor - Banco - Aosncla Emissora & $\begin{array}{l}\text { c) orgäo lécnico de classificação de produtos; } \\
\text { d) Cámara de Mercadorias. }\end{array}$ \\
\hline Assinatura do Co-obrioado Sogurador - Companhla de Seguro & Autentração/ chancela da Central de Reglstros S/A \\
\hline
\end{tabular}


(FRENTE)

CEPTIFICADO DE MISRCADORIA COM EMISSÁO GARANTIDA ${ }^{\circ}$

Entrega Fisica - Disponivel - CMDG

(1) Nome do
detentor do direlto
de uso

\begin{tabular}{|c|c|c|c|c|}
\hline NÚMERO & 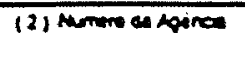 & 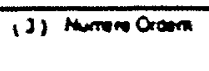 & 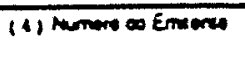 & (s) Stre \\
\hline
\end{tabular}

\section{CLASSIFICAÇĀO DA MERCADORIA}

(6) Me Contenso co Cusutickio:

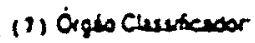

il) Merewone: 110$)$ Tos. (*) Oun du Clusstreacio:

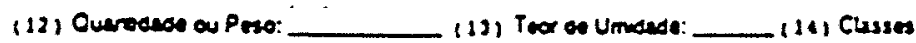

(11) Patrome: ___ (11) Gnos:

(20) Vatase exe:

(19) Conestion:

(21) Our as Amadepio: __

iis) Oubreos

(11) Satra:

(16) Delones:

1

\section{ARMAZENADOR}

(22) Noma:

(23) Cidese:

(2) Amezem N

(24) Au

121) Ous on Erras.

1

(26) UF

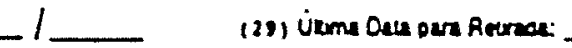

(21) N' 00 Lote.

NERSO)

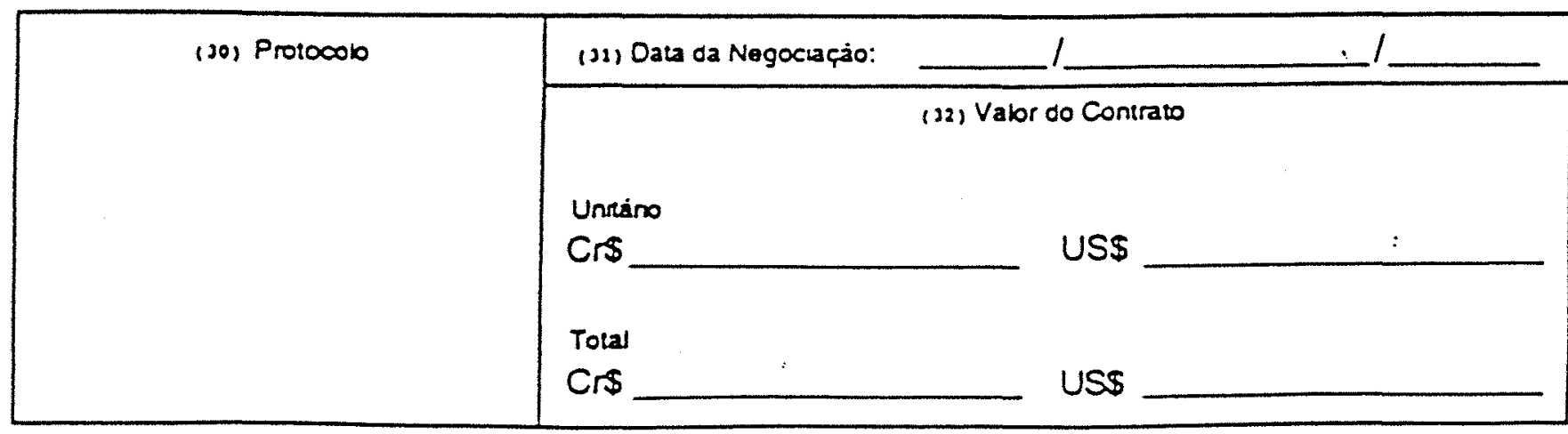

(3) Condrçós Gerais do Negócio:

\begin{tabular}{|l|l|l|l|}
\hline (2) Cliente Vendedor & wsi Corretor Vendedor & (s) Cliente Comprador & (j) Corrotor Compracor \\
$N^{9}$ & $N^{2}$ & $N^{2}$ & $N^{2}$ \\
\hline
\end{tabular}


CERTIFICADO DE MERCADORIA

COM EMISSĀO GARANTIDA $\otimes$

Entrega Futura Garantlda - CMFG

Produtos Agrícolas - Pecuárlos - Agro-Industrlals

\begin{tabular}{|c|c|c|c|c|}
\hline$C M F G-N^{2}$ & Número do Banco / Agäncia & Número Ordem & Série & Número do Emitente \\
\hline Gestora & 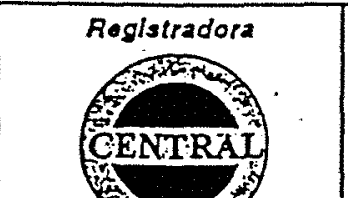 & Garantldor & Garantidora & $\begin{array}{c}\text { Armazenador } \\
\text { - }\end{array}$ \\
\hline
\end{tabular}

\section{EMITENTE - VENDEDOR}

Nome ou Razăo Social:

Inscr. Estadual / Produtor:

$\operatorname{CGC}(M F):$ Endaroço:

\section{CLASSIFICAÇĀO DA MERCADORIA}

\section{PRAZO DE ENTREGA}

A mercadoria constante deste Certificado estará disponivel, classificada $\theta$ armazenada a partir do dia:

at́́ o dia:

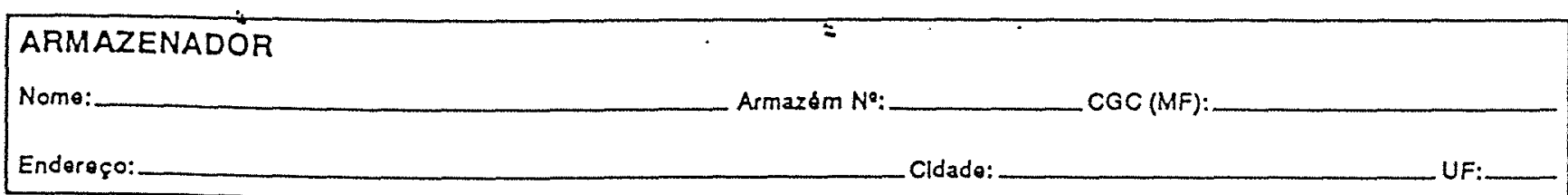

\section{GARANTIDORES CO-OBRIGADOS}

Banco:

CGC (MF):

Cidade:

UF:

Seguradora: CGC (MF):

Cidade:

UF:

\section{GESTORA DOS NEGÓCIOS}

Bolsa do:

$\operatorname{cgc}(\mathrm{MF})$

Endereço:

Cidade:

UF:

\section{REGISTRADOR - COMPENSADOR - LIQUIDADOR}

CENTRAL DE REGISTROS S.A. CGC (MF): $60.158 .839 / 0001-84$

Av. Senador Quelroz, $611-3^{2}$ andar - Săo Paulo - SP

Pelo presente Instrumento particular e para todos os fins de direito, o Emitente-Vendedor e seus Garantidores Co-Obrigados, acima nomeados e Identificados, se comprometem a vender, depositar e a entregar, no Armazenador acima Identificado, a mercadoria supra mencionada no termo de classificação, nos prazos e condiçōes constantes deste instrumento e do Boleto de Venda emitido nos pregōes da Bolsa, ao Comprador, e que, também ficam sujeitas às seguintes cláusulas e condiçōes: (verso) 
1.0 presente Instrumento vem emitido pelo Emitente-Vendedor, com 2 garanta de co-obrloracao do cumprimento das cláusulas Inerentes a venda, pelo Banco, tudo de conformidade com o laudo de classificaçăo oficial tornecido pelos orgzos técnleos credenciados pela bolsa.

2.Esta Certificado de Mercadoria somente poders ser negociado nos pregoes livres e regulares das bolsas e outras congeneres, no pais e no exterior, sendo a revenda elou transferencia de tularidade por registro escritural junto d Central de Registros S/A, tudo conforme seus estatutos e regulamentos.

3.A venda do presente Certificado, Irre de qualquer onus ou gravames, serd reallzada nos termos de Acordo de cliente e Instrumento de Mandato e condlçoes negociais firmado atraves das Sociedades Corretoras onciais nos pregoes da 8olsa.

4.Sobre a negociaçăo do presente certificado Incidirăo taxas, emolumentos e comissoes negociais, que serăo suportadas pelas partes - Vendedor e Comprador, fudo conforma tabela pariodicamente editada e fixada pela Central de Registros S/A.

5.Fica convencionado que O Banco Co-obrigado Garantidor garantira a entrega da mercadoria a o Comprador final até a data de vencimento do presente Certificado, ou da retirada eletiva da mercadorla, se esta ocorrer antes da data de vencimento deste Certińcado, cessando, 2 partir dal, qualquer obrigaça ou responsabilidade a cle atribuida.

6. Este Cerificado de Mercadorla permanecerá custodiado desde a data de sua emlssăo até a data da eletiva retirada da mercadoria pelo Comprador final, Junto a agencia bancaria co-obrigada do EmitenteVendedor, quando perdera sua valldade, pelo vencimento.

7.0 Armazenador Identificado no anverso fica lnvestido de todas as obrigaçoes que sajo atribuidas pela lel ao fiel depositario, Inclusive a de manutença da mercadoria no estado de conservaçăo, conforme ates tado no kudo classificatório reproduzido a este incluso.

8.Săo de responsabilidade do Emitente-Yendedor todas as despesas decorrentes, ate a dadta da pilmeira venda do cerificado, $e$ sucessivamente, dos titulares Vendedores (pro-rata-tempore), saivo condiçờ negociais em contrário.

9. Qualquer reclamaçăo do comprador final em relaçăo à mercadoria, objeto do presente Certincado, deverá ser cléluada até o alo da retirada da mercadoria do Armazenador, nzo sendo aceita, portanto, qualquer reclamaço posteplor a este ato.

10. Os impostos, se Incidentes, Inclusive seu recolhimenio ou ressarcimento, serăo de responsbilidade do Comprador, salvo disposiçăo em conúario prevista em legislaço.
11. Fiam fazendo parte integrante deste Certificado os seguintes documentos, que as partes declaram expressamente o conhecimento e obediencia a todos os seus termos, cláusulas a condiçoes:

a) Laudo de Classincação de Mercadoria, se necessário.

b) Acordo de Cliente e Instumento de Mandato.

c) Estutulo da Bolsa e seus regulamentos.

d) Regulamentos da Central de Registros S/A

e) Regulamentos do Armazenador.

1) Apólice de Seguros, se existentes.

o) Contratos aditivos entre Co-obrloados e Emitente-Vendedor. s? existentes.

h) Contratos aditlvos ente Compradores e Central de Registos S/A.

i) Boleto de Negociaça.

12. Os Co-obrigados Garantidores do Emitente-Vendedor, e pela ordem, se comprometem a eletuar o pagamento da reposiça da mercadoria objeto deste Certificado até o primeiro dia útil saguiniz apcis declarado o Inadimplemento do Emiente-Vendedor ou do Amazenador.

13. A Central de Registros S/A serd a Administradora das garantias dos Contratantes-Compradores, sa comprometendo a repassar a liquidaço do valor constanta da venda do presente Certificado, no mesmo prazo definido na cláusula 12.

14. A mercadoria a ser entregue, obedecera as especificaç⿸es do padrăo de qualidade constante no anverso, conforme limite de toletancia estabelecido pela Camara de Produtos da Bolsa.

15. Fica instituido, como primeira Instancia obrigatória o Julzo Arbitral da Bolsa, para dirimir quisquer divergenncias sugidas no cumprimenio das cláusulas do presente instrumento.

16. Caso qualquer autoridade ferderal, estadual ou municipal venha a editar norma legal que alete, em parte ou no todo, substancialmente os direitos o obrigaçoes criados pelo presente Ceróficado, este poderá ser considerado rescindido, procedendo-se, de Imediato, sta liquidaça compulsória caso, a critério das partes, năo seja encontrada soluçăo amistosa, sem prejuizo dos direitos e obrigaçoes antelomente assumidos.

17. Em caso de extravio ou destruiçăo do presente certificado, o Emitente-Vendedor, o Armazenador, o Custodiador final, deveréo comunicar prontamente, por escrito, à Central de Registros S/A para o consequente cancelamento e autorizaçăo para emlssăo de segunda via. 0 năo cumprimento do disposto no caput desse artigo para fins de direito e garantia de terceiros, prevalecera o registo escritural Junto d Cental de Registros S/A.

EPOR ESTAREM JUSTOSE CONTRATADOS, FIRMAM O PRESENTE EM TODOS OS SEUS TERMOS, PARA OS DEVIDOS FINS DE DIREITO.

raça - Estado

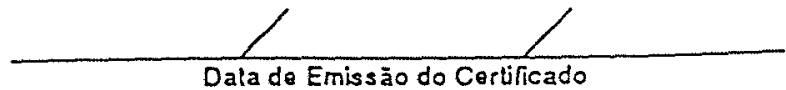

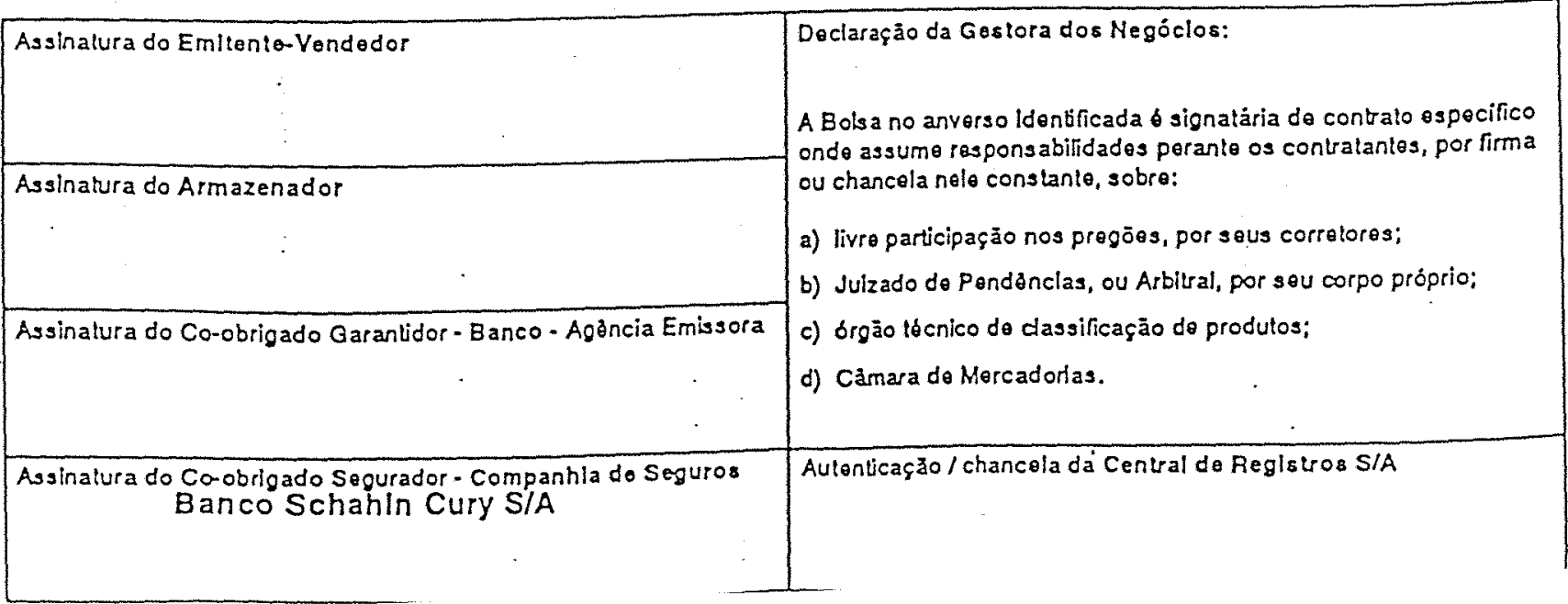




\section{BOLETO DE NEGOCIAÇÃO \\ CM-G - CERTIFICADO DE MERCADORIA COM EMISSÃO GARANTIDA® \\ ENTREGA FUTURA GARANTDA}

\begin{tabular}{|l|l|l|l|l|}
\hline N Ú M E R O & (2) Número da Agència & (3) Nümero Ordem & (4) Número do Emitente & (5) Súrie \\
\hline
\end{tabular}

\section{CLASSIFICAÇÃO DA MERCADORIA COMOPROMUSSADA}

(6) Metcadoria

(8) Safra

(11) Classes

(14) Polimento
(9) Quantidade ou Peso

(12)Quebrados

(15) Grupo
(7) Tipo

(10) Teor de Umidade

(13) Defeitos

(16) Consistência

\section{ARMAZENADOR}

(17) Nome do Ótgão ou da Empresa de Armazenameato (18) Amazém número (19) Rua

(20) Cidade (21) UF

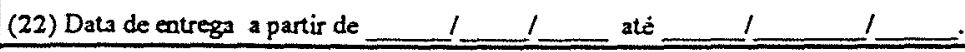

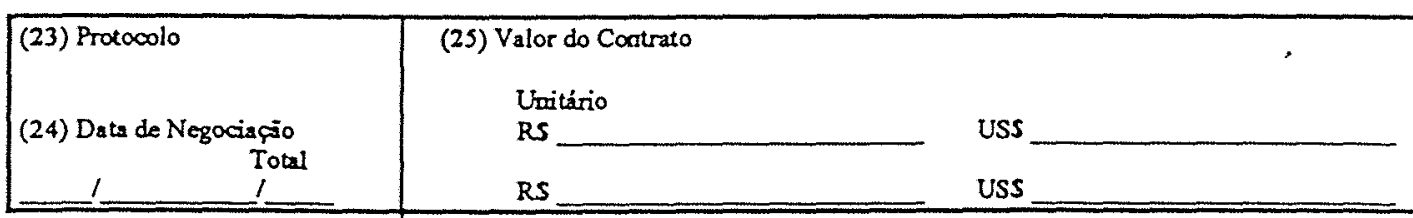

(26) Condipjes Gerais do Negócio:

(27) Cláusula a Termo Irrevogável e Irredrativel:

A presente veads e compra foi realizada com a condicäo obrigatónis de formaçäo prepo e complemento de pegamento fuburo:

1. Neste ato, ajuste prelinaioar de proco e pagameato pelo valor total doclarado no campo (25) deste boleto

2 - Na data da entrega, condicionstmente, 0 complemento de preco, resul tante da seguinte equaspäo de fatores:

2.1. O prego unitírio constante do cano (25) corresponde nesta data a uraa paridade en relaçäo ao indice CBOT do mès correspondente a entrega an seguinte relsçäo:

2.1.1 - batice CBOT ...... USS por buschel;

2.1.2 - Prepo unitáio do campo (25) - RS ...... por staca;

2.2 - O preco uritíio constante do campo (25) correspondeate nesta data a uma paridade en relaço so indice BM\&F-FIPE do mès correspondente a entrega na seguinte rels paio:

2.2.1 - Indice BM\&F-FIPE ...... USS por saca;

2.2.2 - Propo uriticio do (25) - RS ......... por saca;

3. Se na data da eatrega da mercadoria, o prego real praticado pelo mercado, tomendo por base o indice escolbido (2.1. ou 2.2.) se apresertar merar ou maior do que a referíncia escolhida será efetuado um complemento do prepo observadas as seguintes proporcōes:

3.1 - Se a variagio de prego for negativa (menor que o prepo constante do campo (25)) nada sera devido, como complemento de prepo, eatre as partes.

3.2 - Se a variapajo de prepo for positiva, (maior que o preso constante do campo (25), o comprador complementara o valor da mercadoria a favor do vendedor ns seguinte proporyä:

3.2.1 - Conhecida a vaciscäo positiva do prego (paridade escollida e preso real praticado), sobre esta diferenca será destinado ao vendedor - equivaleate a $20 \% .30 \% .50 \%$ desta difereaca.

3.3. A Clearing do Sistema, caso as partes näo se ajustem na interpretagäo das condipöes estabelecidas, arbitrará o contcido da presente cláusula, e na auséncia do prévio depósito do valor apurado a favor do veadedor, autorizará que o mesmo eféte a compensagäo do valor artitrado com a diminaigäo da quantidade correspondente as entrega da mercadoria.

4 - Outras cláusulas e ajustes: todas as que livremente as partes pactasarem.
28) Cliente Vendedor
(29) Corretor Veadedor
(30) Cliente Comprador
(31) Corretor Comprador
$\mathrm{N}^{\mathrm{O}}$
$\mathrm{N}^{\circ}$

$N^{\circ}$

$N^{\circ}$ 


\section{BOLETO DE NEGOCIAÇÃO \\ CM-G - CERTIFICADO DE MERCADORIA COM EMISSĀO GARANTIDA®}

\section{ENTREGA FUTURA GARANTIDA}

(27) Cláusula a Termo Irrevogável e Irretratável:

A presente venda e compra foi realizada com a condição obrigatória de formação preço e complemento de pagamento futuro:

1 -Neste ato, ajuste preliminar de preço e pagamento pelo valor total declarado no campo (25) deste boleto.

2 - Na data da entrega, condicionalmente, o complemento de preço, resultante da seguinte equação de fatores:

2.1 - O preço unitário constante do campo (25) corresponde nesta data a uma paridade em relação ao indice CBOT do mês correspondente a entrega na seguinte relação:

2.1.1 - Índice CBOT ....... US\$ por buschel;

2.1.2 - Preço unitário do campo (25) - R\$ ...... por saca;

2.2 - O preço unitário constante do campo (25) correspondente nesta data a uma paridade em relação ao índice BM\&F-FIPE do mês correspondente a entrega na seguinte relação:

2.2.1 - Índice BM\&F-FIPE ...... US\$ por saca;

2.2.2 - Preço unitário do campo (25) - RS ......... por saca;

3 - Se na data da entrega da mercadoria, o preço real praticado pelo mercado, tomando por base o índice escolhido (2.1 ou 2.2) se apresentar menor ou maior do que a referência escolhida será efetuado um complemento do preço e pagamento da diferença, observadas as seguintes proporções:

3.1 - Se a variação de preço for negativa (menor que o preço constante do campo (25)) nada será devido, como complemento de preço, entre as partes;

3.2 - Se a variação de preço for positiva, (maior que o preço constante do campo (25), o comprador complementará o valor da mercadoria a favor do vendedor na seguinte proporção:

3.2.1 - Conhecida a variação positiva do preço (paridade escolhida e preço real praticado), sobre esta diferença será destinado ao vendedor o equivalente a $20 \% \ldots 30 \% \ldots 50 \%$ ou outro \%..desta diferença;

3.3 - A Clearing do Sistema, caso as partes não se ajustem na interpretação das condições estabelecidas, arbitrará o conteúdo da presente cláusula, e na ausência do prévio depósito do valor apurado a favor do vendedor, autorizará que o mesmo efetue a compensação do valor arbitrađo com a diminuição da quantidade correspondente na entrega da mercadoria;

4 - Outras cláusulas e ajustes: Poderão fazer parte desta cláusula todas as condições negociais que as partes livremente pactuarem para a formação do preço final. Exemplos de situações que poderão. compor a fórmula de fixação do preço final:

4.1 - Base CBOT - cotação CBOT na data do fechamento do negócio indicando o prêmio ou o desconto negociado;

4.2 - Fatores de multiplicação ANEC para preço FOB estivado;

4.3 - Valor das despesas no porto;

4.4 - Frete até porto, ou local da entrega (referência);

4.5 - Câmbio, ICMS, e demais que as partes ajustarem;

4.6 - Base BM\&F ou FIPE - seguir os mesmos procedimentos, lembrando sempre que BM\&F é o preço referencial de partida e FIPE é preço referencial de finalização; 


\section{Acordo de Cliente e Instrumento de Mandato}

Por este instrumento e, na melhor forma de direito, as partes abaixo mencionadas tèm, entre si, justo e contratado o seguinte:

\section{I - Das Partes}

$\left[\begin{array}{l}\text { A- Contratante, o Cliente } \\ \text { Razäo Social / Nome: } \\ \text { Endereso: }\end{array}\right.$

Bairro:

Telalones:

Telex: CGC/CPF: Inscrição Municipal: CEP: Cidade: UF: Ramais: Fax: Inscriço Estadual / RG: Inseriçăo INCRA:

\section{8 - Contratado, a Sociedade Corretora / Corretor \\ Razão Social / Nome: \\ Enderego:}

Bairro: CEP:

Cidade: UF:

Telolones: Ramais:

Telex: Fax: CGC / CPF: Inscrigäo Estadua / RG:

Inscriçāo Municipal:

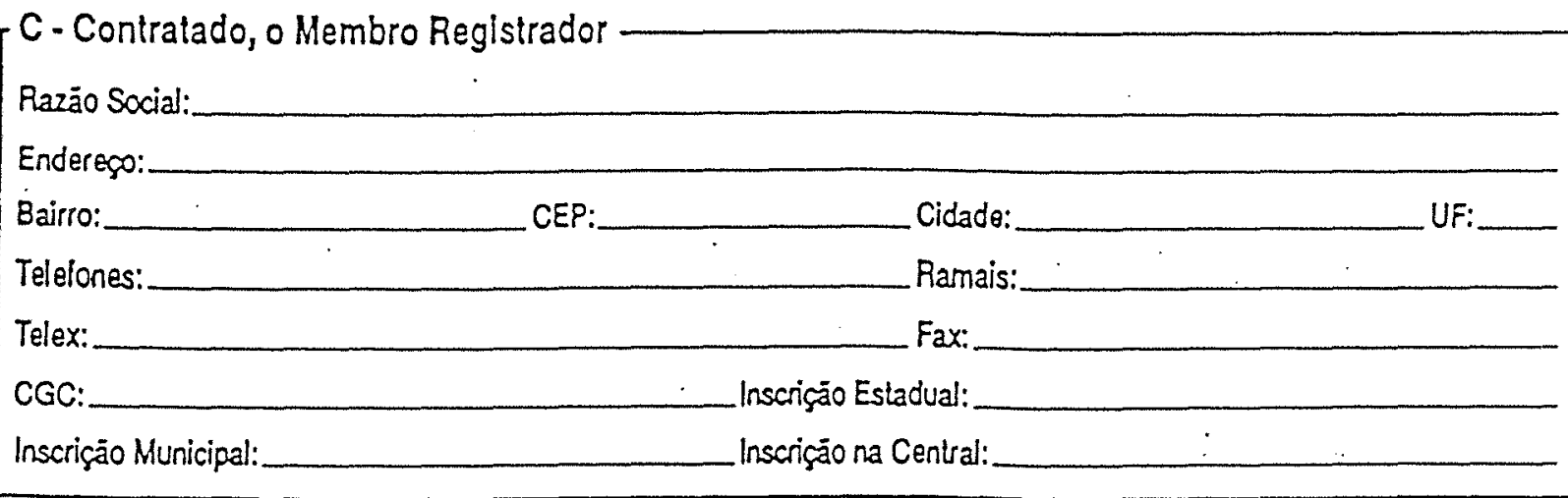

\section{D - Intervenientes}

CENTRAL DE REGISTROS S.A., empresa que registra, compensa $\theta$ liquida os negócios realizados em Bolsa, com sede em Säo Paulo, à Av. Senador Queiroz, 611 - $3^{2}$ andar, Inscrita no CGC sob $n^{2} 60.158 .839 /$ 0001-84, doravante denominada Contratr $\theta$ as Bolsas de Mercadorias e Cereais que mantiverem convẻnio com a Central, neste documento. 
Primeira: O Contatanlo contrata, neslo ato, os Conbalados para que em seu nome e, como sous mandalários:

a. O Corrator, leche negdcios e contralos de compra e venda do mercadorias nos pregöes da Boisa, no mercado lisico e disponivol:

b. O Corrolor, oncaminho tais negócios para registro junto a Cental, através do Membro Registador,

c. O Corrolor, aubscreva documentos rolerentes a esses negocios, em especlal, os Bolelos de Negociação em pregão, os pedidos de arbitragem, o encaminhamento de documentos, garantias, laxas o orecobimenlo de avisos, nob́ficagöes e correspondencias:

d. O Membro hogistra dor, represento o Cliento perante a Cental, proceda ao registro dos negdeics, movimenle os valores financoiros, recebendo o pagando quisquer quandas ou valores rolerenlos aos negdelos do outorgante, registrados na Cental o movimente es documentos ontre a Cental o o Cliente, Inclusive no que se relere aos rapresentabvos das quantias aportadas o ao recebimento de avisos, nobificaşōes o correspondenclas, podendo, para tanto, dar quitaşa. acordar, transigir, enfím praticar lodosfes alos em nome do Clienie, o nos temos dos regulamenlos da Central a da Bolsa:

- A Contral, proceda o registro, a compensaçäo, a llquidaçào o toda movimenlagão financeira desses negócios;

1. A Contral, procoda a liquidagăo compulsória, de negócios de responsabilidade do Contalante, quando previsto em regulamento da Bolsa o da Contral;

9. A Contral, proceda a ubilizaģå, movimentaçäo lovantamento das garantias e disponibilidades do Contatante perante a ola Cental.

Segunda: O Contatanto declara estar de pleno gozo das tranqulas legais para exarer o direito de realizar negócios e contalos no mercado fisico o disponivel, regulamenlados pola Bolsa o pola Central o nosta rogistrados e que, para os dovidos fins do clreito, assumo a exelusiva - Inlelra responsabilidade polos mesmos, quando realizados pelos mandatários Contatados, na vigäncia deslo contralo.

Torceira: O Contratanlo declara conhecor e acoilar inlegralmente lodas disposiçöes dos Estahtos Sociais o Regulamenlos da Bolsa - da Cental, dedarando alnda estar clente da possibilidade de Instituiçăo do novas modalidades operacionajs ou alteraçóes regulamentares, para as quais o Correlor o Membro Rogistador lorá mantidos os poderes a oles outorgados na claúsula primeira, renunclando desde já a qualquerpleilo undado em desconhedmento de estabutos, regulamentos, nomas ou delerminagoós da Bolsa da Cental.

§ Único: O Contralanle declara ostar cienle de que esses regulamentos, normas e deleminaçōes da Bolsa e da Cental - stáo sujaitos a alteraçðos, omanadas da Bolsa e da Cental dentro do principio de aulo-regulamentagão que Thes conferem os respectivos Estatutos o Regulamentos correspondentes, bem como das emanadas das autoridades govemamentals. O Corrolor o Membro Registrador obrigam-so a comunicat ao Contalante, Imodialamenie, loda o qualquer áleração a que se relere osle Item.

Quarta: O Contratanie declara que submelerá eventuais pendẻncias, oriundas de negócios realizados na Boisa, ao Juizo Arbilral desta, obrigando-so a acalar suas declsỏos, comoúlima Instảncia administrativa.

Quinla: Os Contalados, Correlor-Membro Registrador, obrigam-so a remeler, de Imediato, ao Contalanio iniomes sobre as -xecuçōes de ordens de negoclos realizados no pregăo da Bolsa, as quals seräo consideradas como aprovadas, caso o Contatante não apresente, por escrito, notificasăo de falta de recebimento desses Inlomes até dois dias úteis após cada execuçăo.

$\because$

Sexta: O Contatanie, quando vendedor, assume lobal responsabilidade pela plena posse, propriedado o disponibilidade da mercadoria por ele ou a sua ordem olertada em pregão da Bolsa. Responde, também, pela fiel transmissão do bem vendido, observando os prazos, quanidades, qualidades e oulos liens deserllos em Bolelos de Negociagão, que passam a fazer parte iniogranle do presento Acordo.

Sétma: O presenie Instrumento ef fimado por prazo Indeleminado, podendo ser denunciado por qualquer das partes, medianto aviso prévio fomal de trinta dias.

Oilava: Estingue-so, no entanlo, o presente compromisso, com rolerẻncia aos negódios já realizados, somente após o lármino das obrigaçöos aqul assumidas, bem como, após cessados os eloilos, Inclusivo pagos lodos os dábilos dos Contalanles, oriundos direla ou Indirolamenle do presente instrumento.

Nona: O prosente instumento á assinado em cáálerlnovogável e irrolralável, obrigando sucessores o herdelros.

Déclma: As partes elegem o Foro da Comarca da Cidade de São Paulo, com expressa renúncia a qualquer outro, pormais privilegiado que possa ser, para nele serem dirimidas quisquer dúvidas ou lilígios decorrenles desle Acordo.

de de 199

\begin{tabular}{|l|l|}
\hline Contratanilo (assinalura(s) autorizada(s)) \\
\hline Contralado- Corrolor(a) & Contralado-Membro Registrador \\
\hline Teslemunha (qualificar) & Teslemunha (qualificas) \\
\hline
\end{tabular}

